\title{
Colapso de edifício por ruptura das estacas: estudo das causas e da recuperação
}

\section{EDUARDO GIMENEZ DE SOUZA}

Dissertação apresentada à Escola de Engenharia de São Carlos, da Universidade de São Paulo, como parte dos requisitos para a obtenção do Título de Mestre em Engenharia de Estruturas.

Orientador: Libânio Miranda Pinheiro, Prof. Dr.

São Carlos

2003 
Dedico aos meus pais,

Erasmo e Sueli que sempre me apoiaram. 


\section{AGRADECIMENTOS}

A Deus, que me iluminou em todos os momentos, e tornou possível a obtenção deste título, que representa mais uma etapa conquistada em minha vida.

Ao Professor Libânio Miranda Pinheiro pela orientação, sugestões e dedicação durante a realização deste trabalho.

Aos Professores Márcio Roberto Silva Corrêa e Nelson Aoki pelas importantes contribuições ao trabalho.

Ao Professor Carlos Eduardo Moreira Maffei pelo importante material e esclarecimentos fornecidos.

A todos os funcionários do Departamento de Estruturas da EESC - USP, que me auxiliaram durante o processo. Especialmente a Rosi e a Nadir.

A Coordenadoria de Aperfeiçoamento de Pessoal de Nível Superior CAPES, pela bolsa de estudo concedida.

A todos os amigos do Departamento de Estruturas da EESC - USP, pelo agradável convíveo.

A Juliana pelo constante incentivo, apoio e compreensão, demonstrados durante todo esse período. 


\section{SUMÁRIO}

RESUMO — I

ABSTRACT _ II

\section{INTRODUČ̃̃}

1.1 ASPECTOS GERAIS _ _ 01

1.2 JUSTIFICATIVA

1.3 OBJETIVO _ 03

1.4 CONTEÚDO _ 04

\section{CONDOMÍNIO ANÊMONA}

2.1 PROCESSO OCORRIDO DURANTE A CONSTRUÇÃO ___ 05

2.2 LOCALIZAÇÃO E DESCRIÇÃO __ 06

2.3 DESCRIÇÃO ESTRUTURAL __ 08

2.3.1 Fundação _ـ 08

2.3.2 Aterro _ 09

2.3.3 Estrutura de Transição ___ 11

2.3.4 Estrutura e Alvenaria___ 12

2.3.5 Acabamento _ 15

2.4 HISTÓRICO DO DESABAMENTO___ 16

\section{ESTUDO DAS CAUSAS}

3.1 OBJETIVO DO CAPÍTULO___ 24

3.2 REVISÃO BIBLIOGRÁFICA____ 25

3.2.1 Estudo dos Solos da Baixada Santista___ 25

3.2.2 Classificação dos Solos Finos___ 26

3.2.3 Deformação ao Longo do Tempo - Adensamento ___ 28

3.2.4 Tensão no Solo e Empuxo___ 30

3.2.5 Investigações Geotécnicas____ 32

3.3 SOLO DE FUNDAÇÃO DO TERRENO___ 35

3.4 CAUSA DA RUPTURA DA ESTACA___ 41

3.5 AÇÕES NAS ESTACAS DEVIDO A SUPERESTRUTURA___ 45 
3.5.1 Modelagem__ 45

3.5.2 Carregamento nas Vigas de Transição___ 51

3.5.3 Valores das Reações nas Estacas___ 56

3.6 EFEITO DO EMPUXO LATERAL NAS ESTACAS___ 57

3.6.1 Verificação sem Considerar o Empuxo Lateral___ 57

3.6.1-a Cálculo das Características Geométricas da estaca $n^{\circ} 10 \_58$

3.6.1-b Determinação dos Esforços Solicitantes __ 59

3.6.1-c Verificação do cisalhamento ___ 62

3.6.1-d Dimensionamento da Armadura Longitudinal___ 62

3.6.2 Verificação Considerando o Empuxo Lateral____ 64

3.6.2-a Método de Tschebotarioff___ 65

3.6.2-b Método de Beer e Wallays___ 68

3.7 ANÁLISE DOS RESULTADOS___ 72

\section{PROJETO DA RECUPERAĊ̃̃O ESTRUTURAL}

4.1 OBJETIVO DO CAPÍTULO__ _ 73

4.2 ETAPAS PRELIMINARES___ 73

4.2.1 Procedimentos Adotados Logo Após o Colapso___ 73

4.2.2 Estabilização dos Edificios___ 74

4.2.2-a Bloco " $A$ " 74

4.2.2-b Bloco " $B$ " 79

4.2.3 Instrumentação___ 82

4.3 PROCESSO DE RECUPERAÇÃO___ 86

4.3.1 Sistema Provisório de Fundações___ 86

4.3.2 Paredes Provisórias___ 90

4.3.3 Estrutura Metálica___ 93

4.3.4 Macaqueamento e Escoramento___ 98

4.3.5 Reconstrução do Pavimento Térreo _ 100

4.4 PROBLEMAS VERIFICADOS DURANTE A OBRA___ 101

\section{CONCLUSÕES FINAIS}

5.1 MOTIVOS DO ACIDENTE__ 102

5.2 INVIABILIDADE DO PROJETO DE RECUPERAÇÃO__ 102

REFERÊNCIAS BIBLIOGRÁFICAS__ 105

ANEXO__ 108 
SOUZA, E. G. (2003). Colapso de edificio por ruptura das estacas: estudo das causas e da recuperação. São Carlos. 115p. Dissertação (Mestrado) Escola de Engenharia de São Carlos, Universidade de São Paulo.

A maior parte dos acidentes em edifícios, causados por falhas de projeto ou de execução, ocorre na fase de construção. Além de causar prejuízos financeiros, eles colocam em risco a vida dos trabalhadores da obra. Porém, mais graves são os acidentes verificados após o término da construção. Além dos prejuízos serem muito maiores, eles podem envolver pessoas de todos os tipos, crianças, mulheres e idosos.

São muitos os casos em que o colapso global do edifício decorre de problemas na fundação. Esse é o caso do edifício considerado neste trabalho, localizado no Litoral Norte do Estado de São Paulo. Trata-se de um edifício para veraneio, em alvenaria estrutural, com garagem no térreo e quatro andares de apartamentos, apoiado em estacas pré-moldadas, cravadas em solo instável.

Pouco tempo após a conclusão e parcialmente ocupado, apresentou recalques e patologias significativas que exigiram providências, reforço de pilares de alvenaria inclusive. Antes que fossem detectadas as causas dos recalques, durante uma madrugada, o edifício desabou: em um lado do edifício, o primeiro pavimento encostou-se ao chão. Felizmente, era um dia-de-semana, fora da alta temporada, e não havia pessoas no seu interior. Também o vigia estava fora do edifício e nada sofreu, além de um grande susto.

Os objetivos deste trabalho são descrever o problema ocorrido com esse edifício e analisar as causas e as providências possíveis para sua recuperação, já que os andares superiores praticamente nada sofreram. Serão apresentados os resultados de uma investigação no local e de uma análise para determinação dos esforços e das causas da ruptura das estacas, que provocaram o colapso do edifício.

Ficou evidente que o aterro localizado sobre o pavimento térreo e o sistema de fundação do edifício não estavam adequados para o tipo de solo do terreno. Tais fatores tiveram papel fundamental para a ruptura do sistema.

A importância de se conhecer minuciosamente essas causas transcende a presente obra, pois pelo mesmo motivo, outras construções podem apresentar danos semelhantes.

Palavras chave: colapso estrutural, recalques, solo instável, ruptura de estacas, recuperação estrutural 
SOUZA, E. G. (2003). Building collapse for piles rupture: Study of the causes and recovery. São Carlos. 115p. Dissertação (Mestrado) - Escola de Engenharia de São Carlos, Universidade de São Paulo.

Most of the buildings accidents, caused by project flaws or of execution, it happens in the construction phase. Besides causing financial damages, they put in risk the workers life. However, more serious accidents are verified after the end of the construction. Besides the damages are larger, they can involve all types of people, children, women and senior.

In many cases the global building collapse elapses of foundation problems. That is the case of the building considered in this work, located in the North Coast of São Paulo State. Treated of a building for summer vacation, in structural masonry, with garage in the earthy pavement and four floors of apartments, leaning in premolded piles, nailed in unstable soil.

After the conclusion and partially in use, it presented repress and significant pathologies that demanded providences, column masonry reinforcement besides. Before detected the repress causes, during one dawn, the building tumbled: on a side of the building, the first pavement was leaned to the ground. Happily, it was a weekday, out of the high season, and there were not people inside. Also the watchmen was out of the building and nothing suffered, besides a great fright.

The objectives of this healthy work are to describe the problem happened with that building, to analyze the causes and the possible providences for it recovery, since the superior walks practically nothing suffered. The results of a local investigation, an analysis for determination the efforts and the causes of the piles rupture will be presented, that provoked the building collapse.

It was evident that the located embankment on the earthy pavement and the building foundation system, they were not adapted for the soil type of the land. Such factors had fundamental paper for the system rupture.

The importance of knowing those causes thoroughly, transcends to present work, because for the same reason other constructions can present similar damages.

Keywords: structural collapse, unstable soil, repress, piles rupture, structural recovery. 


\section{CAPÍtULO 1}

\section{INTRODUÇÃO}

\subsection{ASPECTOS GERAIS}

$\mathrm{Na}$ procura incessante de estar sempre praticando a melhor aplicação financeira, os empreendedores, muitas vezes através de análises de mercado, optam por direcionar seus capitais para o setor imobiliário. Surgem, então, os grandes residenciais, condomínios, centros comerciais, entre outros empreendimentos.

Dada a alta demanda de consumo, muitas vezes são executadas edificações em regiões pouco apropriadas para a prática construtiva, como terrenos providos de charcos, mangues e solos ruins. Nesses casos, se não forem aplicadas as técnicas corretas de construção, os empreendedores acabam por produzir edificações com reduzida qualidade de funcionamento.

Um exemplo recente é a movimentação das habitações localizadas na Baixada Santista - pelo fato da região possuir um solo de péssima qualidade e residenciais com fundações rasas, não apropriadas para o terreno. Em Santos, há registros de edifícios de 17 pavimentos, com mais de dois metros de desaprumo.

Apesar das dificuldades construtivas encontradas nessas localidades, a Engenharia Nacional mostrou-se competente e vem conseguindo solucionar problemas que há anos desafiavam os grandes especialistas da área.

Em janeiro de 2001, foi reinaugurado o bloco "A" do edifício "Núncio Malzoni”, situado na já citada Baixada Santista, que se apresentava com $210 \mathrm{~cm}$ de desaprumo e recalque diferencial de $45 \mathrm{~cm}$. De acordo com a matéria publicada no jornal “O Estado de São Paulo" em 4 de dezembro de 2000, quando seu estado foi diagnosticado, em 1995, evidenciou-se que o prédio vinha sofrendo inclinação da ordem de um centímetro por ano. Com essa progressão, estimou-se que sua vida útil terminaria em apenas mais dez anos. 
O trabalho uniu técnicas diversas, que compreenderam: fundações profundas, vigas de transição e macaqueamento. Devido ao alto grau de conhecimento exigido, o estudo requereu especialistas de várias áreas da Engenharia.

Constatou-se que a maioria dos prédios com inclinação foram construídos nos anos de 60 e 70 e, já nessa época, especialistas alertavam para um futuro problema.

Consciente da necessidade de superar as dificuldades e adotar soluções economicamente viáveis para essas falhas construtivas, a engenharia atual desdobrase para desenvolver métodos de recuperação estrutural, não só para os edifícios localizados em Santos, mas também para uma série de outras edificações dispersas pelo Território Brasileiro.

\subsection{JUSTIFICATIVA}

Hoje em dia nota-se que muitos dos edifícios têm em torno de 50 anos de idade. Como é sabido, todas as obras possuem vida útil e estão sujeitas a avarias graves, se não forem submetidas a manutenções adequadas após esse tempo. Não é por mero acaso que constantemente são noticiados novos casos de edificações cujas estruturas ruíram pelos mais diversos problemas.

Um episódio lamentável muito divulgado pela mídia pode exemplificar a complexidade de tal problema: em 22 de fevereiro de 1998, parte do Edifício "Palace II", localizado na cidade do Rio de Janeiro, desabou e matou oito pessoas e, apesar da construtora ter emitido um parecer técnico declarando que o restante do prédio estaria seguro, na semana seguinte desabaram mais 22 apartamentos.

Nesse acontecimento a perícia técnica provou a culpa dos construtores. $\mathrm{O}$ laudo produzido pelo CREA-RJ em 30 de dezembro de 1998 constatou que as causas do desabamento foram vários erros de projeto e execução. Diante do perigo de desabamento do restante do edifício, bem como dos riscos para os prédios vizinhos, a Justiça autorizou a Prefeitura a implodir totalmente o Palace II. Até hoje as famílias, que tiveram o seu patrimônio lesado no episódio, brigam na justiça pelas devidas indenizações. 
Em 17 de maio de 2001, outro desabamento ocorreu, mas desta vez na cidade litorânea de Ubatuba - SP: o bloco "B" do condomínio "Anêmona", que se situa na Praia das Toninhas, apresentou sério colapso em suas fundações, de tal ordem que as estacas afundaram aproximadamente dois metros, quase provocando a ruptura do prédio por completo. Ficou constatado que o solo do local foi o principal responsável pela ruína e, após o acidente, o edifício continuou apresentando recalque, da ordem de $5 \mathrm{~cm}$ por mês, o que exigiu celeridade nas medidas cabíveis.

A princípio duas hipóteses foram estudadas: demolição e reconstrução do bloco danificado ou a recuperação estrutural, deslocando-o para sua cota original. Uma empresa especializada de Engenharia, a mesma que realizou a recuperação estrutural do bloco "A" do já citado edifício "Núncio Malzoni", foi contratada para avaliar a gravidade do caso.

É relevante registrar que na região existem outros condomínios que podem estar sujeitos aos mesmos problemas averiguados no "Anêmona". Este trabalho traz para si a constatação da importância da verificação das reais condições estruturais desses edifícios, a fim de que sejam evitados futuros sinistros.

É por essa razão que o meio técnico tem de estar apto a antever e dar prosseguimento nas soluções cabíveis para casos como esses. Evidentemente, optando sempre pela solução mais viável, que cause menores perdas materiais e emocionais aos envolvidos. Para tanto é de suma importância que haja a publicação de trabalhos científicos que almejem contribuir com a divulgação e o acréscimo de informações nessa área.

Será o episódio verificado no Condomínio Anêmona o objeto apreciado neste trabalho. O presente estudo servirá, com efeito, como um alerta para os outros condomínios situados próximos ao "Anêmona", que poderão vir a sofrer os mesmos problemas.

\subsection{OBJETIVO}

A presente dissertação é um estudo de caso do ocorrido com o condomínio "Anêmona". Ela está fundamentada na pesquisa das causas que originaram o sinistro e a viabilidade da reabilitação estrutural sugerida por especialistas da área. 
Está descrito nela todo o problema verificado, bem como, também, os agentes responsáveis pelo acidente e os projetos de recuperação desenvolvidos.

\subsection{CONTEÚDO}

Para dissertar didaticamente a respeito deste tema, o trabalho está dividido em cinco capítulos. Abaixo se encontram os assuntos referentes a cada um deles.

\section{- Capítulo 2}

O presente capítulo apresenta as características geométricas e estruturais do condomínio "Anêmona", objeto de estudo deste trabalho, conforme exposto anteriormente. Também está apresentado todo o problema estrutural pelo qual o bloco "B" passou aos 17 de maio de 2001.

\section{- Capítulo 3}

No capítulo 3 está descrito qual foi o fator preponderante para a ocorrência do acidente. O capítulo faz, também, uma análise envolvendo as estacas de fundação, com o objetivo de verificar os esforços nesses elementos.

\section{- Capítulo 4}

Neste capítulo está contemplada a descrição do projeto de recuperação estrutural, desenvolvido por especialistas da área.

\section{- Capítulo 5}

Por fim estão apresentadas as conclusões e algumas considerações finais a respeito dos estudos realizados durante toda a execução da presente dissertação. 


\section{CAPÍtULO 2}

\section{CONDOMÍNIO ANÊMONA}

\subsection{PROCESSO OCORRIDO DURANTE A CONSTRUÇÃO}

O “Condomínio Anêmona” teve o seu lançamento no final do ano de 1993, pela “Construtora e Incorporadora Técnica Ltda”. Para a execução da obra, estipulou-se, entre as partes envolvidas no empreendimento, o contrato de Simples Administração, conhecido como contrato a preço de custo.

Dois anos depois, a referida construtora entrou em processo de falência, o que paralisou vários empreendimentos imobiliários a ela atrelados, na região de Ubatuba - dentre eles, o "Condomínio Anêmona".

Para dar prosseguimento às obras, levantou-se o capital necessário para finalizar o que já havia sido construído, e, com base nesse valor, foi estipulado um contrato a Preço Fechado, com a "R. P. A. Construtora e Incorporadora LTDA". Esta, apesar de não ter participado das atividades precedentes, assumiu inteiramente a responsabilidade técnica do empreendimento.

Nessa nova etapa de construção, 35\% dos condôminos optaram pelo financiamento oferecido pela Caixa Econômica Federal, e os $65 \%$ restantes quitaram as parcelas diretamente com a nova construtora.

As obras prosseguiram até o final, de acordo com o novo cronograma, e no mês de março de 2001, as chaves das unidades dos dois blocos foram entregues aos proprietários. 


\subsection{LOCALIZAÇÃO E DESCRIÇÃO ARQUITETÔNICA}

O condomínio residencial Anêmona localiza-se no bairro das Toninhas, no perímetro urbano da cidade litorânea de Ubatuba-SP. O terreno de $1540 \mathrm{~m}^{2}$ é delimitado pela Avenida Marginal, Rua “B”, Rua Tainha, e Loteamento Jardim Beira Mar (figura 2.1).

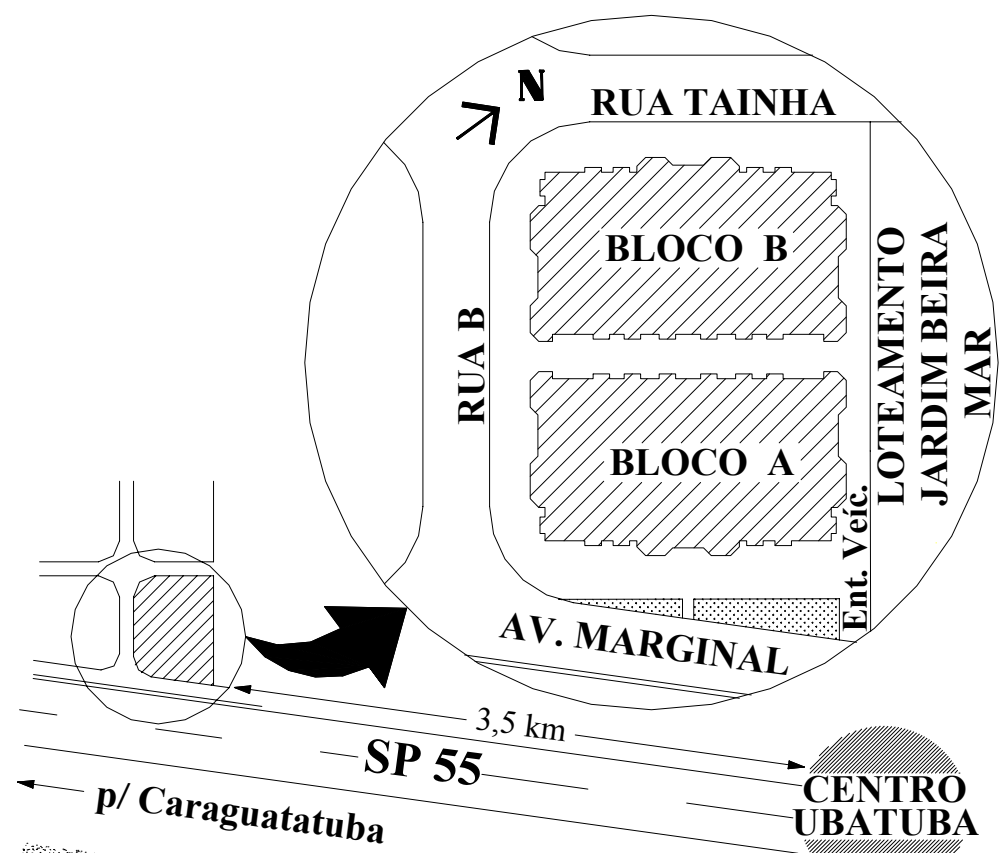

\section{PRAIA DAS TONINHAS}

Figura 2.1 - Localização do Condomínio Anêmona.

O referido residencial possui 48 apartamentos, distribuídos em dois blocos de quatro andares cada um, totalizando $3837 \mathrm{~m}^{2}$ de área construída. Os blocos são compostos por seis apartamentos em cada andar, sendo que as unidades do último pavimento contêm um mezanino em nível superior, conforme mostra a figura 2.2.

Cada edifício tem uma caixa de escada e um elevador com capacidade para seis pessoas. $\mathrm{O}$ acesso ao residencial, tanto para pedestres quanto para automóveis, 
faz-se pela $A v$. Marginal, paralela à SP-55. No térreo constam apartamento do zelador, lavanderia comunitária, área privativa de cada apartamento destinada para depósito e 48 vagas de estacionamento para os condôminos.

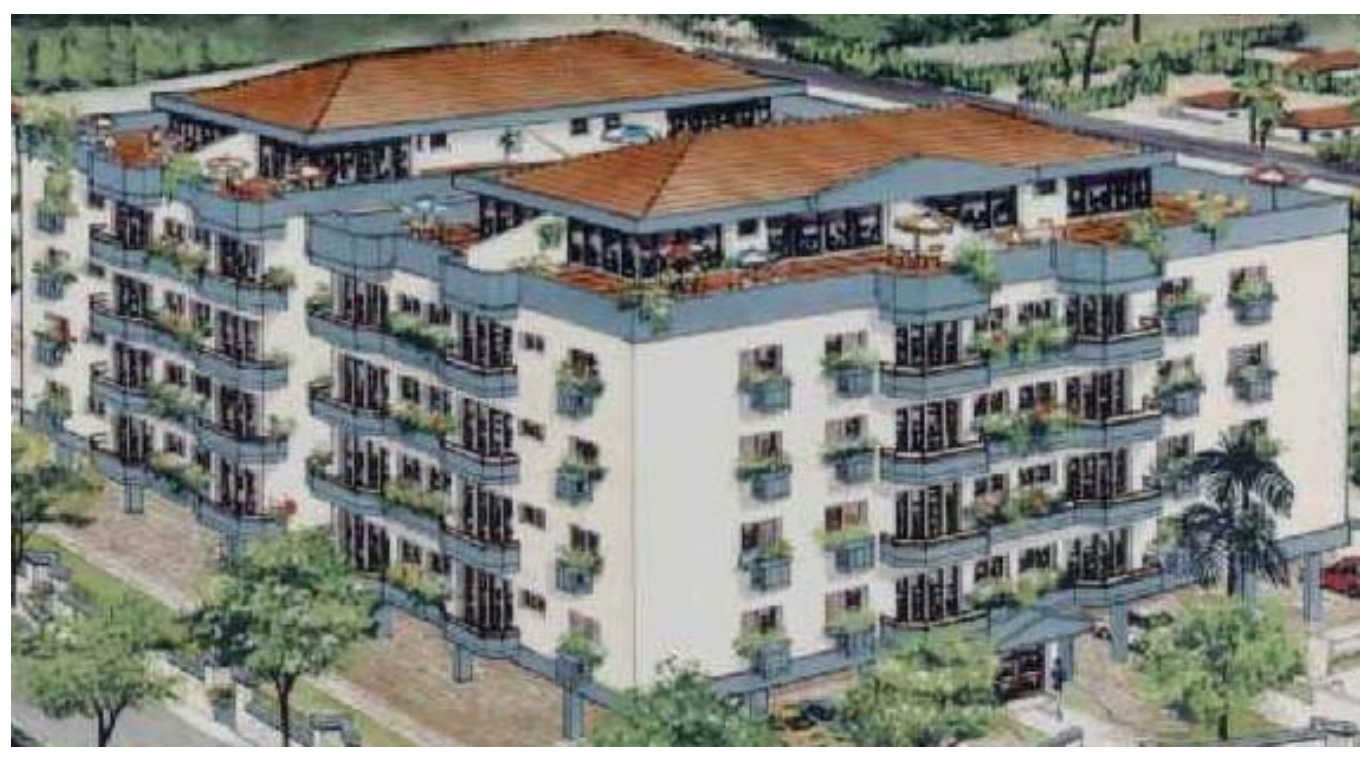

Figura 2.2 - Fachada do Condomínio Anêmona: folheto de propaganda. 


\subsection{DESCRIÇÃO ESTRUTURAL}

Neste item serão detalhados elementos suficientes para a interpretação da concepção do condomínio. A seguir será descrita de que maneira foram realizadas as seguintes tarefas: fundação, aterro, estrutura de transição, alvenaria e acabamento. Algumas plantas do projeto estrutural do edifício estão apresentadas em anexo, no final do trabalho.

\subsubsection{FUNDAÇÃO}

A fundação foi executada com estacas pré-moldadas de concreto armado, com $30 \mathrm{~cm}$ de diâmetro. Elas foram cravadas por marteletes mecânicos até uma profundidade média de $25 \mathrm{~m}$ abaixo do nível inicial do terreno. As vigas-baldrame descarregam diretamente as ações nas estacas, sem intermédio de blocos de transição. Pode-se observar na figura 2.3 o posicionamento de todos os elementos estruturais que compõem a fundação do edifício.

Os pilares são unidos às vigas-baldrame por meio de chumbadores. A figura 2.4 mostra uma destas vigas, que por algum motivo, foi inutilizada durante a fase construtiva. Nela pode-se observar as armaduras de espera, dispostas enfileiradas e afastadas de aproximadamente $40 \mathrm{~cm}$ umas das outras.

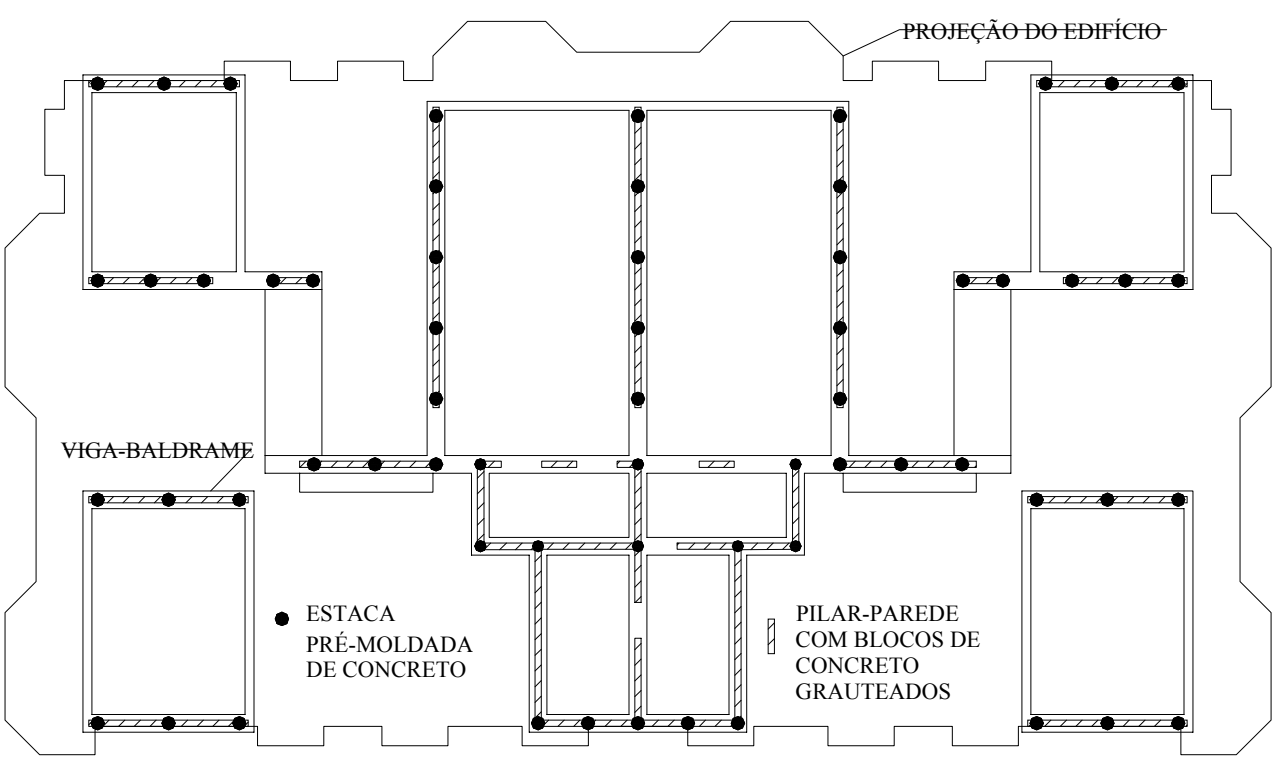

Figura 2.3 - Disposição das estacas, vigas-baldrame e pilares. 


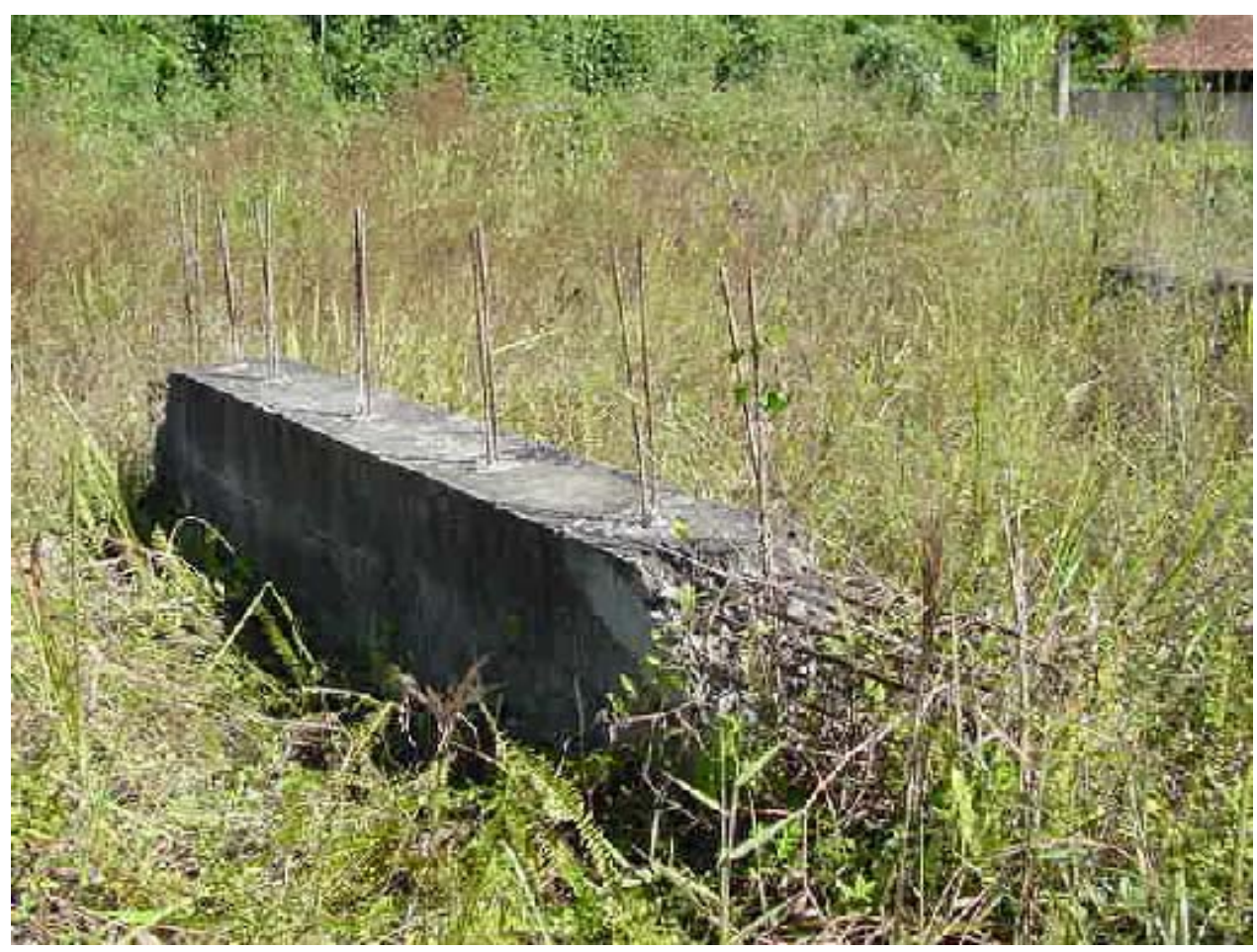

Figura 2.4 - Viga-baldrame inutilizada, com os chumbadores para o pilar-Maffei Engenharia.

\subsubsection{ATERRO}

Foi realizado um trabalho na divisa de fundo do condomínio, com a finalidade de canalizar um córrego que flui por ali. Deste modo possibilitou-se urbanizar e instaurar uma rua no local. Com o intuito do edifício posicionar-se a uma altura segura de possíveis transbordamentos, seu nível foi elevado aproximadamente dois metros e, para isso, foi feito um aterro em toda área delimitada pelo terreno. A figura 2.5 mostra, à esquerda, a região alagadiça localizada nos fundos do condomínio e, à direita, o aterro do condomínio em estudo.

No capítulo 3 será comentada com mais propriedade a relevância desse aterro no processo que culminou com a ruptura das estacas da fundação, acarretando a ruína do edifício.

No quarteirão do lado esquerdo do terreno em apreço encontra-se uma construção abandonada, cujos projetos estrutural e arquitetônico foram efetuados pela mesma construtora do condomínio Anêmona. A figura 2.6 mostra esta construção, abandonada antes do término da segunda laje. Observa-se que as vigas- 
baldrame estão muito acima do nível original do terreno, evidenciando a necessidade de uma camada espessa de aterro para nivelar o primeiro pavimento.

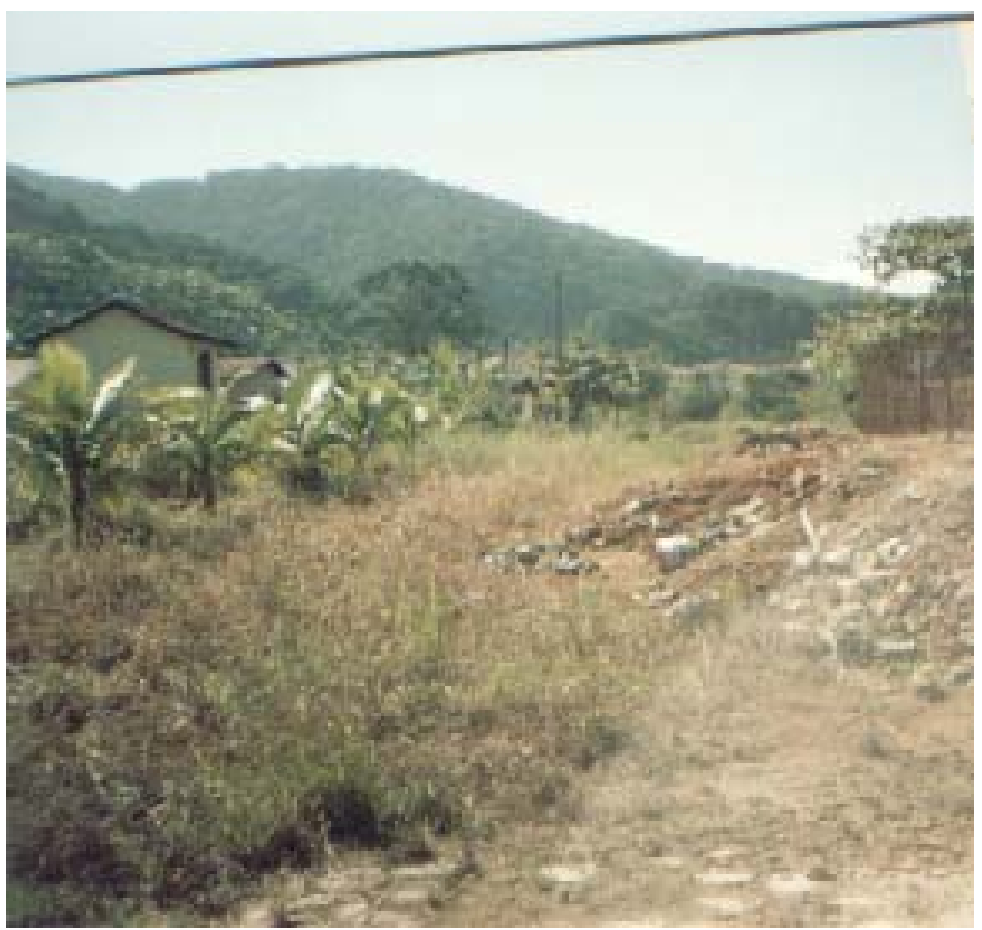

Figura 2.5 - Região Alagadiça Localizada no Fundo do Terreno.

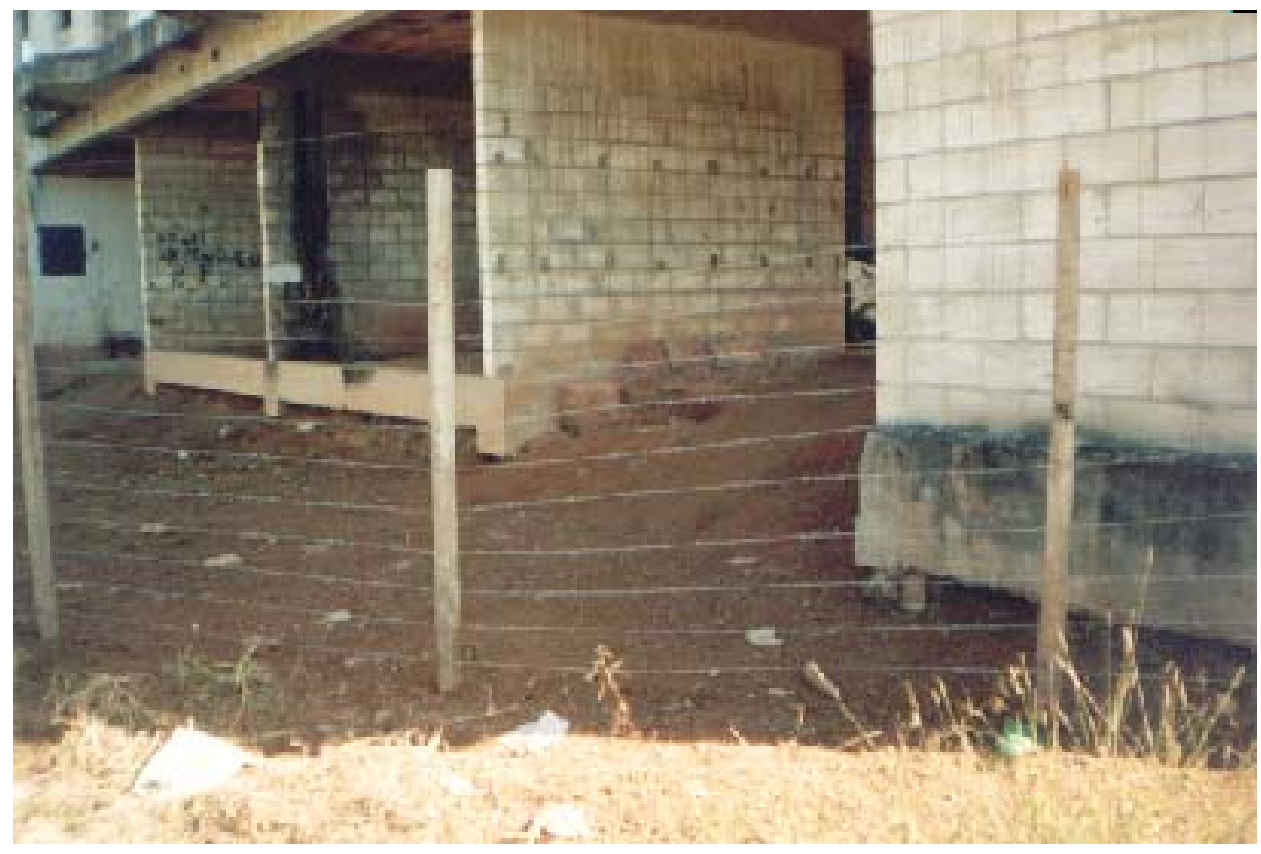

Figura 2.6 - Vigas - baldrame muito acima do nível inicial do terreno. 


\subsubsection{ESTRUTURA DE TRANSIÇÃO}

Para propiciar o travamento adequado da estrutura, foram construídas vigas de concreto armado no nível superior do térreo, apoiadas nos pilares-parede.

Como elemento superficial de transição entre o térreo e o pavimento-tipo, foram construídas lajes com nervuradas pré-fabricadas de $\mathrm{h}=15 \mathrm{~cm}$. A figura 2.7 mostra em planta a disposição desses elementos sobre seus respectivos apoios e o sentido das vigotas. As lajes dos pavimentos superiores foram construídas com placas pré-fabricadas protendidas tipo alveolar $\left(\mathrm{h}=12 \mathrm{~cm}\right.$ e sobrecarga $\left.=450 \mathrm{~kg} / \mathrm{m}^{2}\right)$.

A figura 2.8 exibe a laje de transição utilizada na construção abandonada, ao lado do terreno do edifício que desabou.

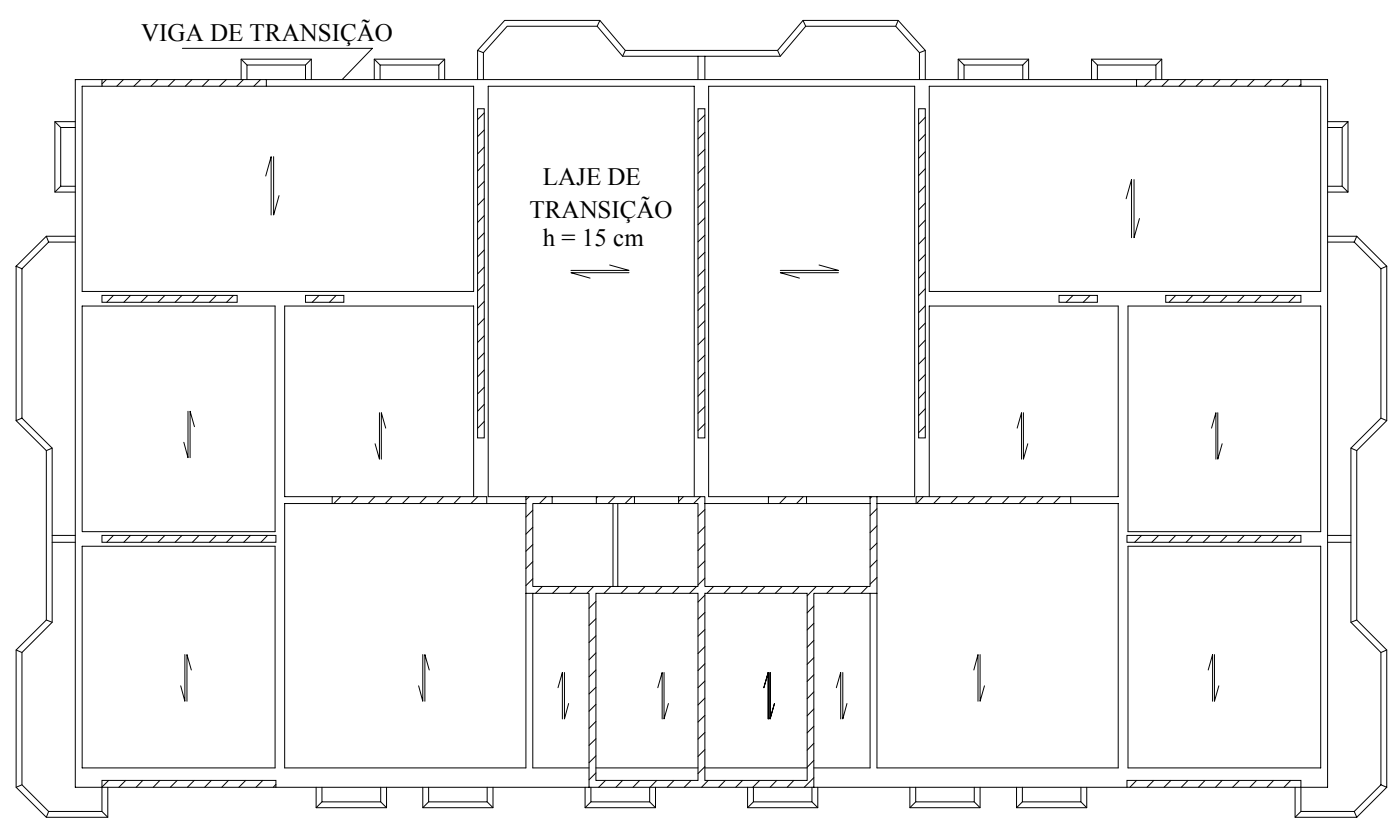

Figura 2.7 - Estrutura de transição. 


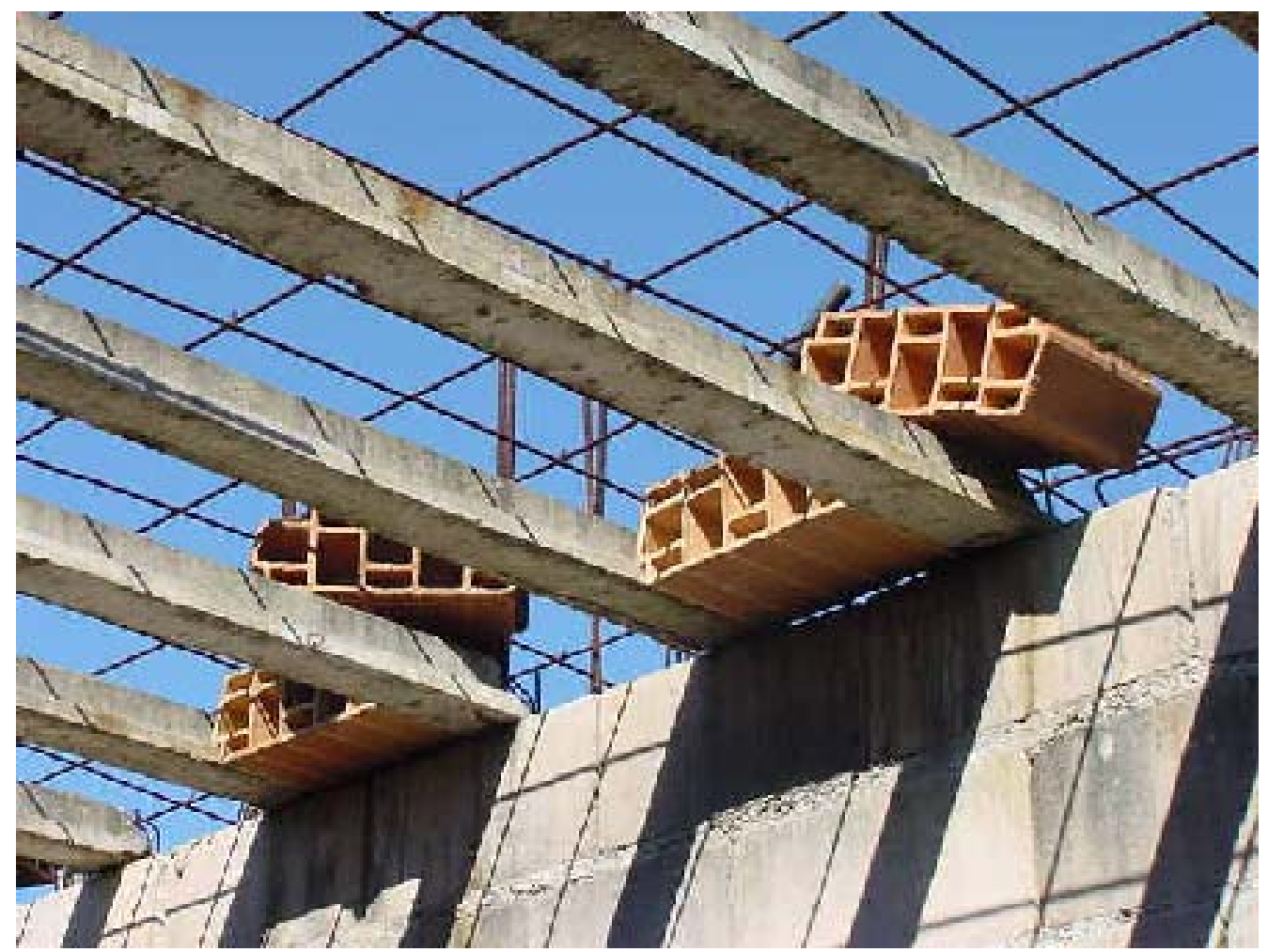

Figura 2.8 - Laje de transição - Maffei Engenharia.

\subsubsection{ESTRUTURA E ALVENARIA}

A alvenaria armada foi construída com blocos estruturais de concreto (14 x 19 x $39 \mathrm{~cm}$ ). A parede, neste edifício, desempenha um papel importante, visto que é responsável pela sustentação deste. No pavimento térreo, no qual a arquitetura diferencia-se dos demais andares, foram construídos pilares-parede com grautes nos vazios dos blocos. A figura 2.9 apresenta os pilares da obra abandonada no quarteirão ao lado, conforme mencionado em precedentes considerações. Constata-se que eles foram feitos com uma grande quantidade de graute, o que pode ser observado na parte superior deles; nota-se a grande quantidade de armadura de espera para junção com a estrutura de transição.

Toda alvenaria foi construída de maneira reforçada, com amarrações nos encontros perpendiculares a cada duas fiadas (figura 2.10), vergas e contravergas nos vãos de portas e janelas e graute em alguns blocos. 


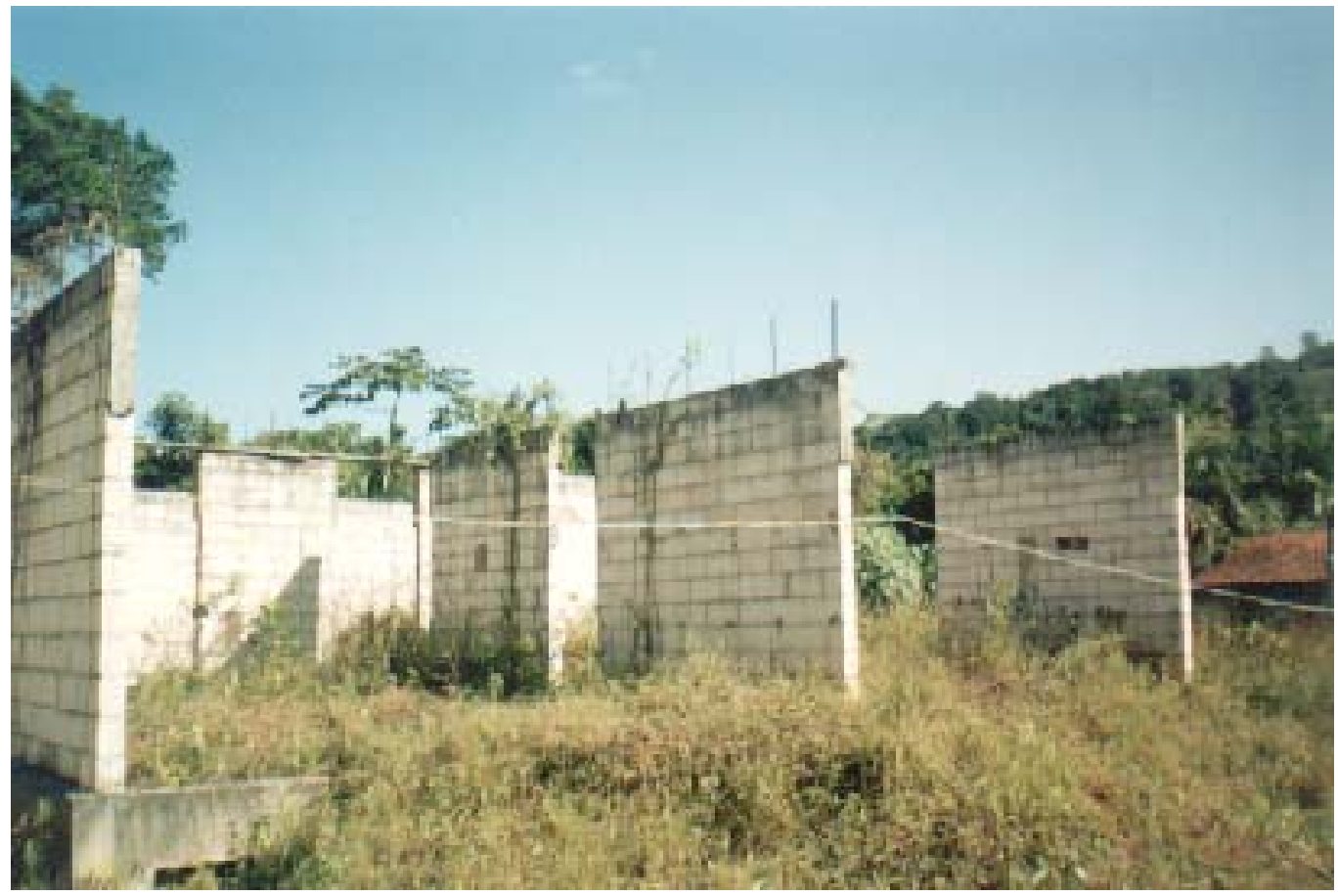

Figura 2.9 - Pilares-parede da obra abandonada no quarteirão ao lado - Maffei Engenharia.
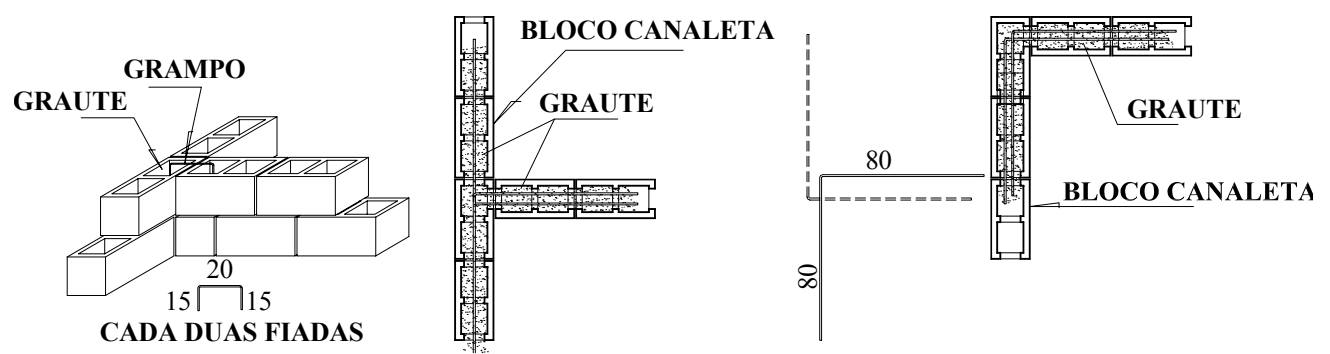

Figura 2.10 - Detalhe de encontro das paredes.

A figura 2.11 exibe em perspectiva as vigas de transição e, logo abaixo, as vigas-baldrame. Os pilares foram dispostos suficientemente afastados para abrigar os veículos no pavimento térreo.

O pavimento-tipo divide-se em seis apartamentos residenciais, sendo três destes dispostos em cada lado do edifício, com um eixo de simetria situado entre as caixas de elevador e escada (figura 2.12).

As paredes indicadas por linha simples na figura 2.12 simbolizam alvenarias não estruturais, com função exclusiva de separação entre ambientes. As demais divisórias são estruturais e responsáveis pela sustentação dos painéis de laje. 
No nível superior de cada pavimento há algumas vigas de concreto armado moldadas "in loco". Elas servem de apoio para as lajes nos vãos de portas e corredores. A figura 2.13 apresenta os locais onde foram construídos estes elementos e indica o sentido dos painéis protendidos.

O último pavimento, que abriga os apartamentos de dois andares, foi coberto por telhado de duas águas, com estrutura de madeira de lei e acabamento de telhas cerâmicas tipo colonial.

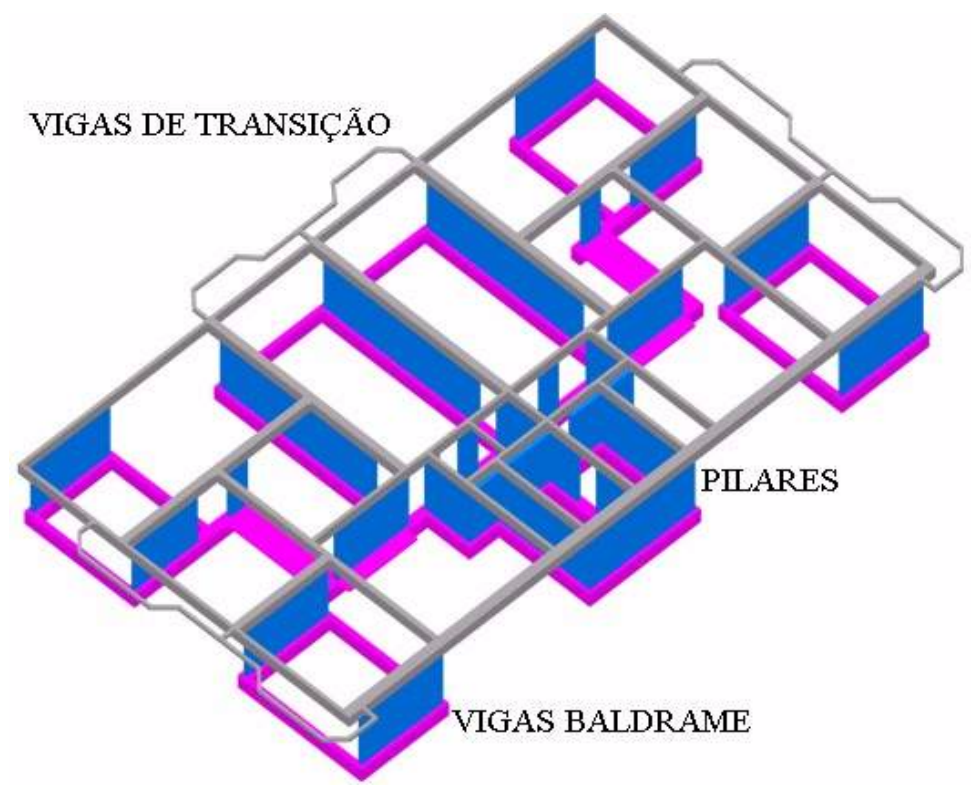

Figura 2.11 - Estrutura de transição.

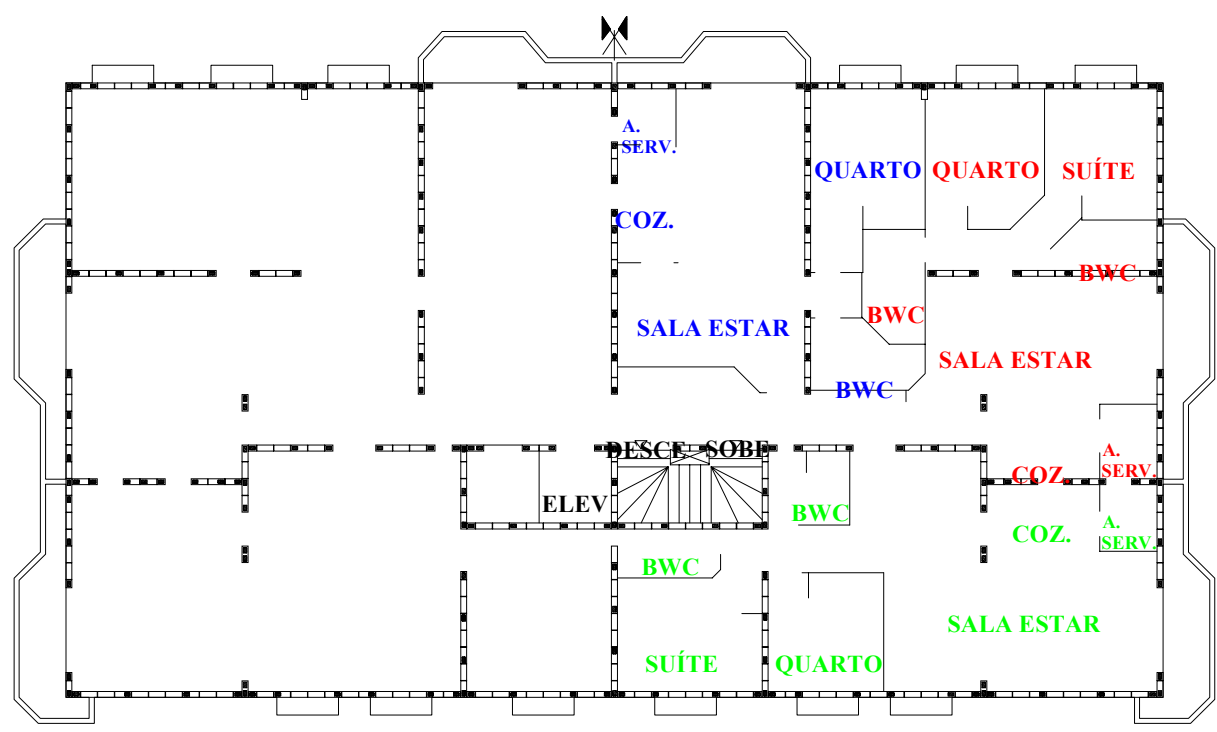

Figura 2.12 - Arquitetura do pavimento tipo. 


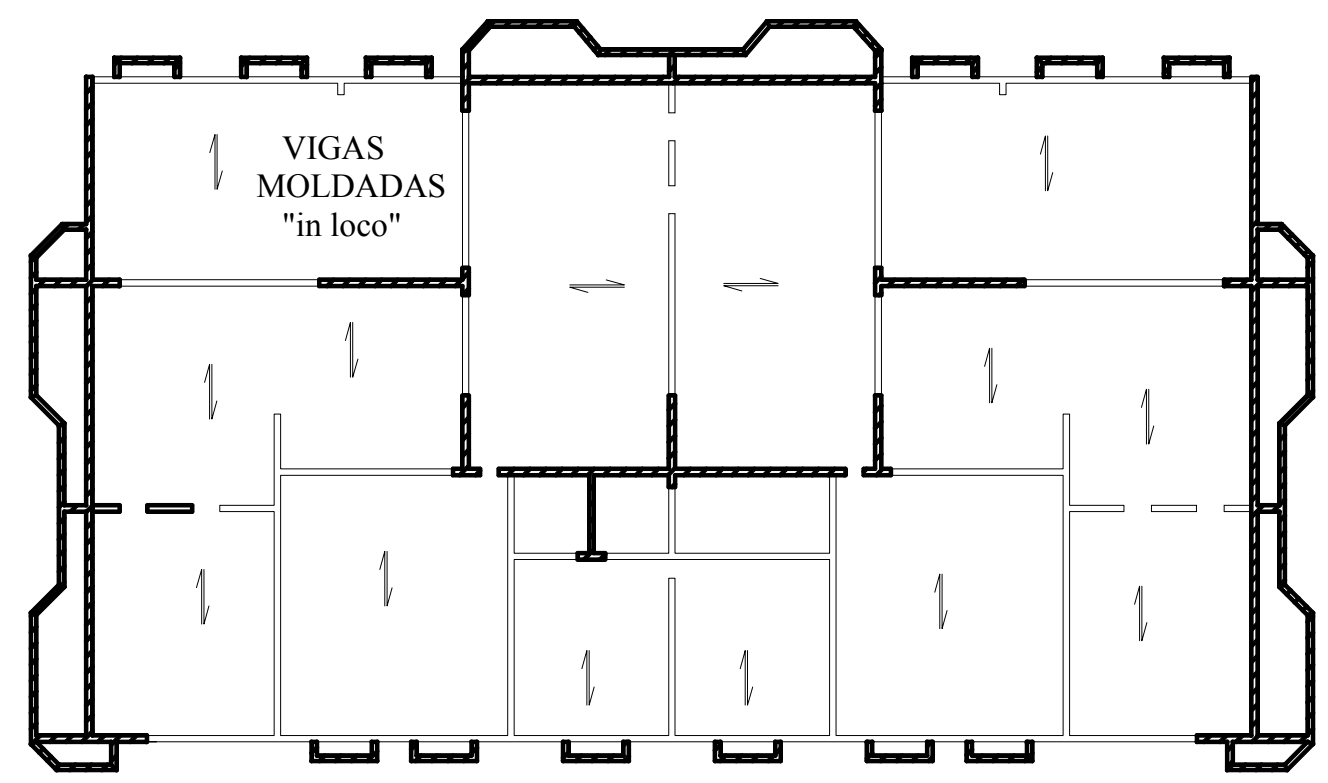

Figura 2.13 - Vigas de concreto armado moldadas "in loco".

\subsubsection{ACABAMENTO}

Emboço e reboco foram feitos no revestimento externo e, internamente, foi aplicado emboço e também massa fina de gesso. Em áreas molhadas, tais como sanitários, copas e cozinhas, foram dispostos azulejos até o teto.

A pintura interna foi efetuada com tinta à base de látex sobre base preparada de massa corrida. Externamente, o edifício ostenta acabamento simples, apenas com pintura também à base de látex.

Assentaram-se blocos sextavados de concreto no piso do estacionamento e, para o acabamento dos apartamentos, bem como para as áreas sociais de circulação, utilizou-se ardósia de cor cinza.

As janelas dos quartos e salas foram feitas de vidros simples e lisos, esquadrias e grades de alumínio. As portas internas de madeira foram encabeçadas com mogno e batentes de cedro.

Visando esconder a tubulação sanitária, foram aplicados forros falsos de gesso nos banheiros e áreas de serviço. Os lavatórios foram montados sobre bancada de granito, pias e tanques de aço inoxidável e torneiras de acabamento cromado. 


\subsection{HISTÓRICO DO DESABAMENTO}

Em 17 de maio de 2001, o bloco "B" do condomínio em estudo sofreu desabamento parcial de sua estrutura, devido à ruptura do seu sistema de sustentação. A figura 2.14 mostra um panorama de como o edifício acomodou-se depois do colapso.

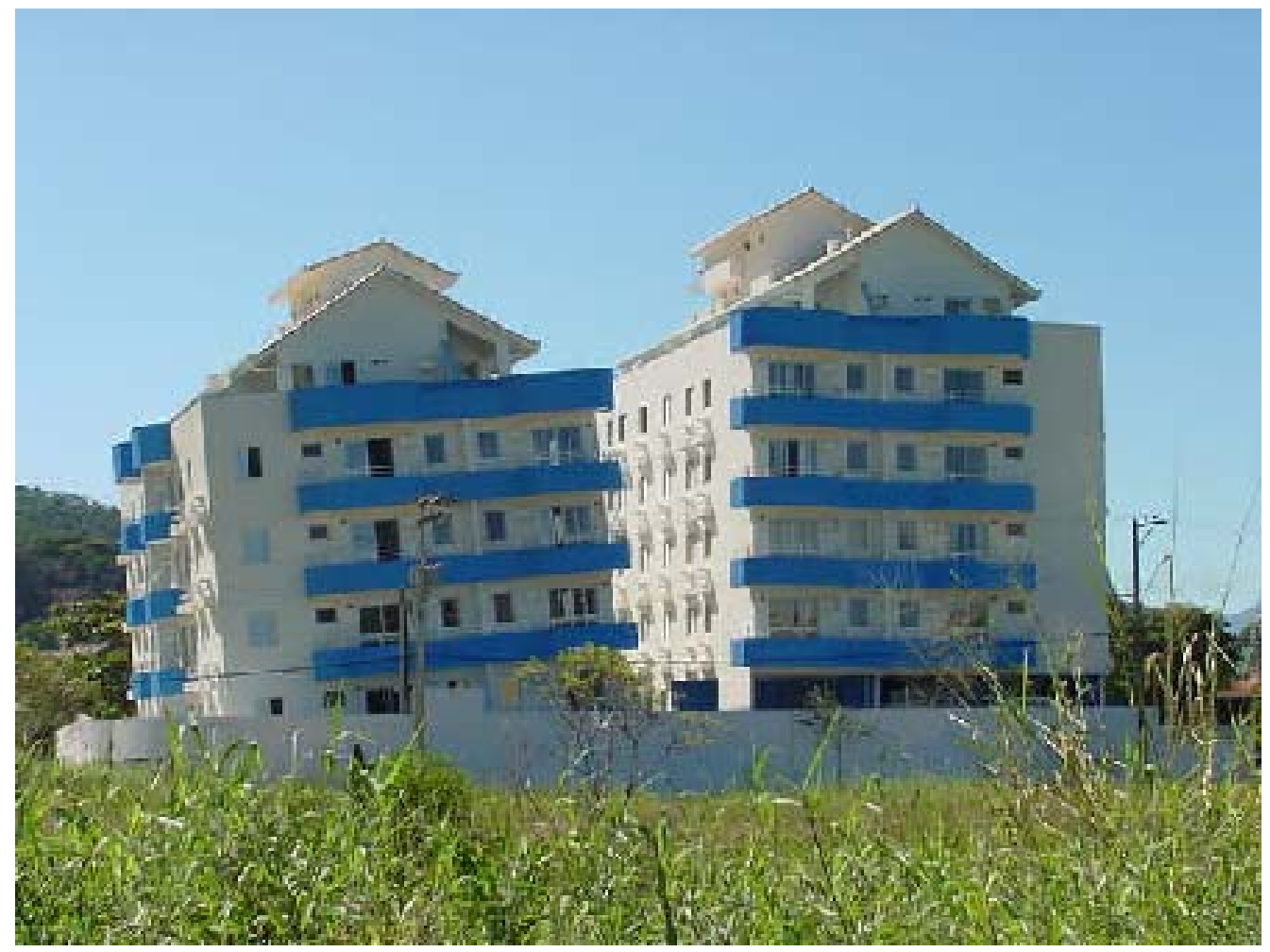

Figura 2.14 - Panorama do edifício deslocado - Maffei Engenharia.

O conjunto cedeu aproximadamente dois metros até o momento em que a laje de transição do teto do andar térreo apoiou-se no solo, descarregando todo o peso sobre este último. A figura 2.15 exibe, do lado direito, o bloco "A" intacto e, do lado esquerdo, o bloco "B" recalcado, sem o pavimento térreo. 


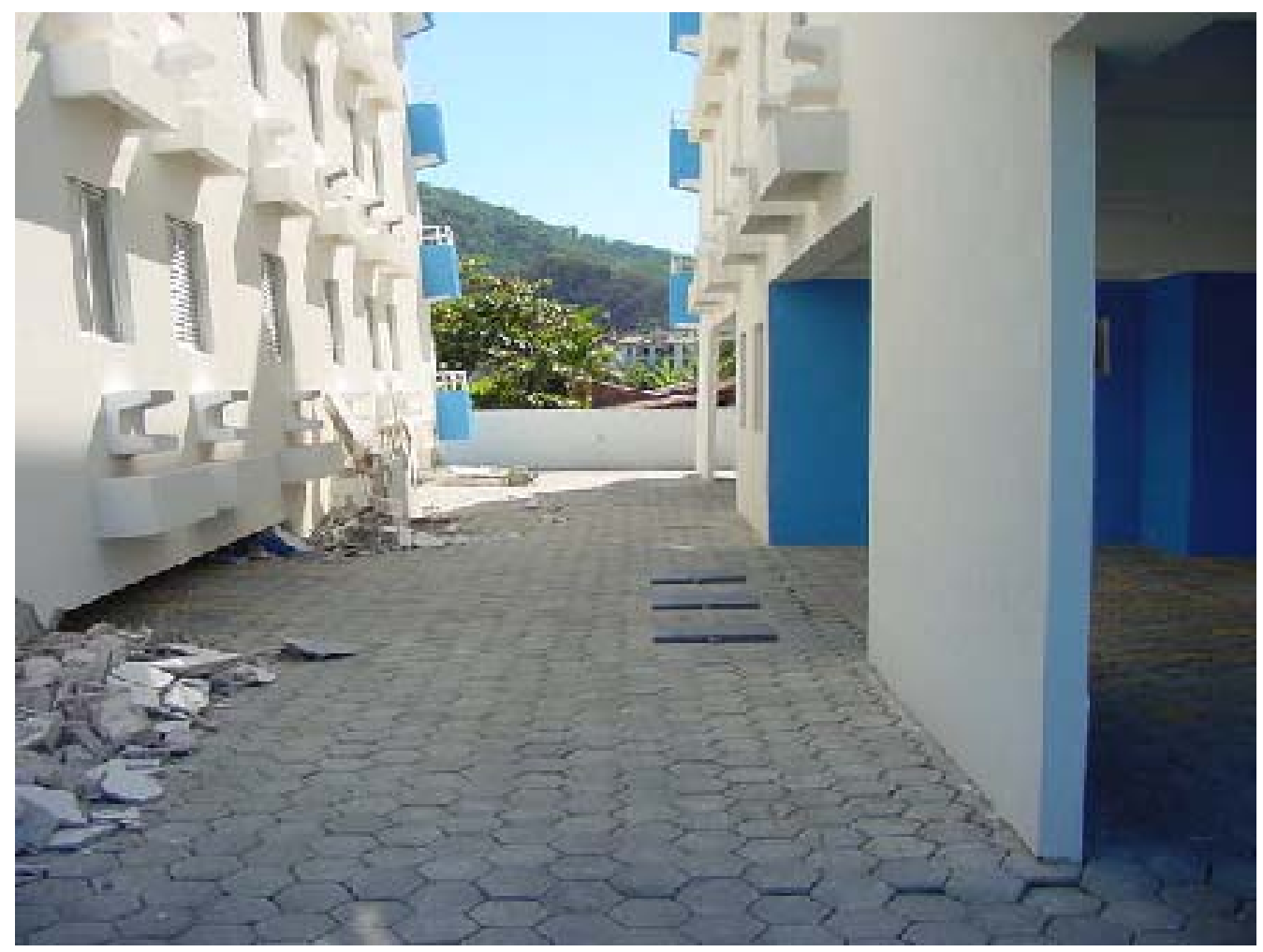

Figura 2.15 - Edificio recalcado apoiado sobre a superficie do térreo - Maffei Engenharia.

Além deste deslocamento vertical, ocorreram outras duas movimentações do conjunto: translação horizontal para o sentido dos fundos (Rua Tainha) e pequena rotação no sentido anti-horário, isto é, tomando-se como referência a Av. Marginal em relação à Rua Tainha. A figura 2.16 ilustra esse fato e compara-o com a posição original da edificação.

Com a movimentação a estrutura acomodou-se de maneira inclinada, o que ocasionou o desaprumo de 2,5m entre o topo da torre à base.

Com exceção do térreo, no qual evidenciou-se a completa destruição do pavimento, surpreendentemente os demais pavimentos da estrutura mantiveram-se íntegros, sem grandes fissuras ou avarias graves. Isto pode ser verificado na figura 2.17, que mostra de que modo ficaram as paredes internas do edifício, depois do desabamento. 


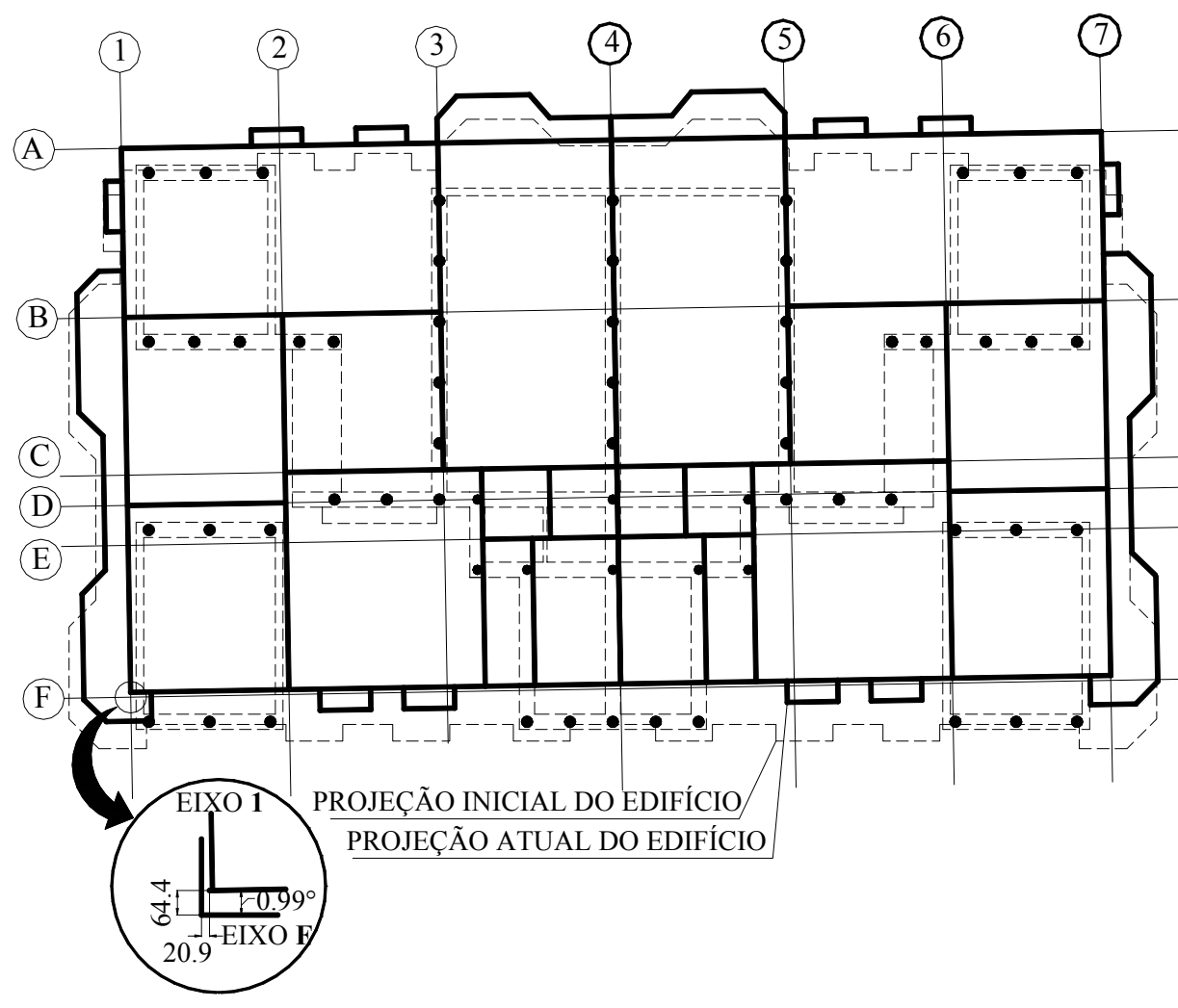

Figura 2.16 - Deslocamento horizontal do edificio.

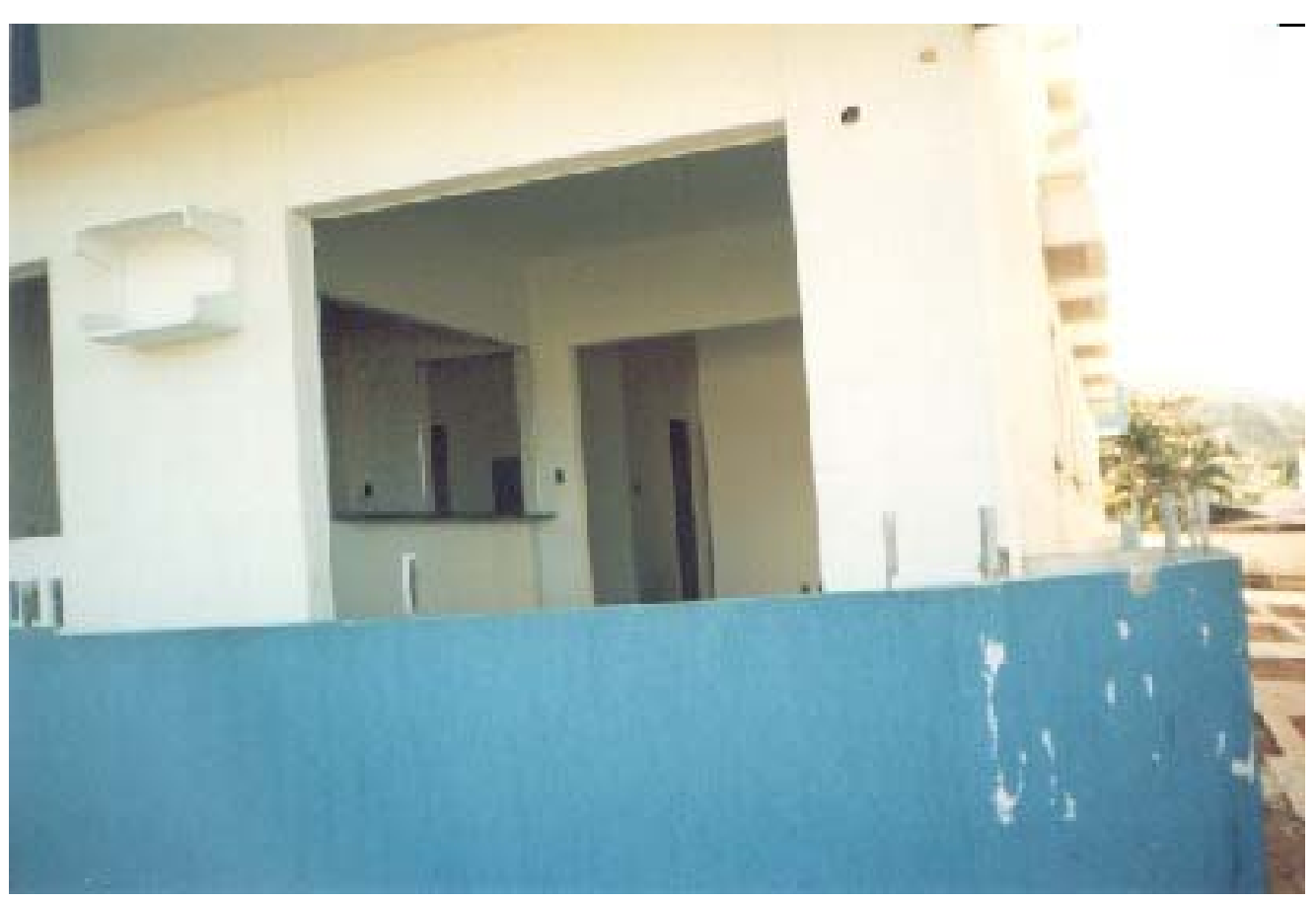

Figura 2.17 - Alvenaria restante sem grandes avarias - Maffei Engenharia. 
Segundo depoimento colhido informalmente do vigia, que era a única pessoa que se encontrava no local na hora do colapso, todo o deslocamento ocorreu repentinamente, sem mostras prévias de uma possível ruptura da estrutura.

Um fato de grande importância foi observado e descrito pelos condôminos: semanas antes do acidente, um grande deslocamento de aproximadamente $30 \mathrm{~cm}$ ocorreu em todo o piso do estacionamento sob o bloco "B". Acreditou-se, na época, ser apenas uma compactação exagerada do aterro, devido ao grande peso empregado pelo solo e, segundo os proprietários, tal problema foi corrigido com o acréscimo de mais solo até atingir a cota final de projeto. Será abordado no capítulo 3 que esse recalque estava anunciando um provável acidente com o sistema de sustentação da estrutura, o que, na realidade, ocorreu.

Esse deslocamento também foi verificado no estacionamento do bloco "A", mas de forma bem menos perceptível, se comparada com o caso relatado no bloco "B”. A figura 2.18 comprova esse fato - pode-se observar na fotografia que o piso está ligeiramente côncavo no centro do estacionamento e com arestas nas regiões localizadas sobre as vigas-baldrame.

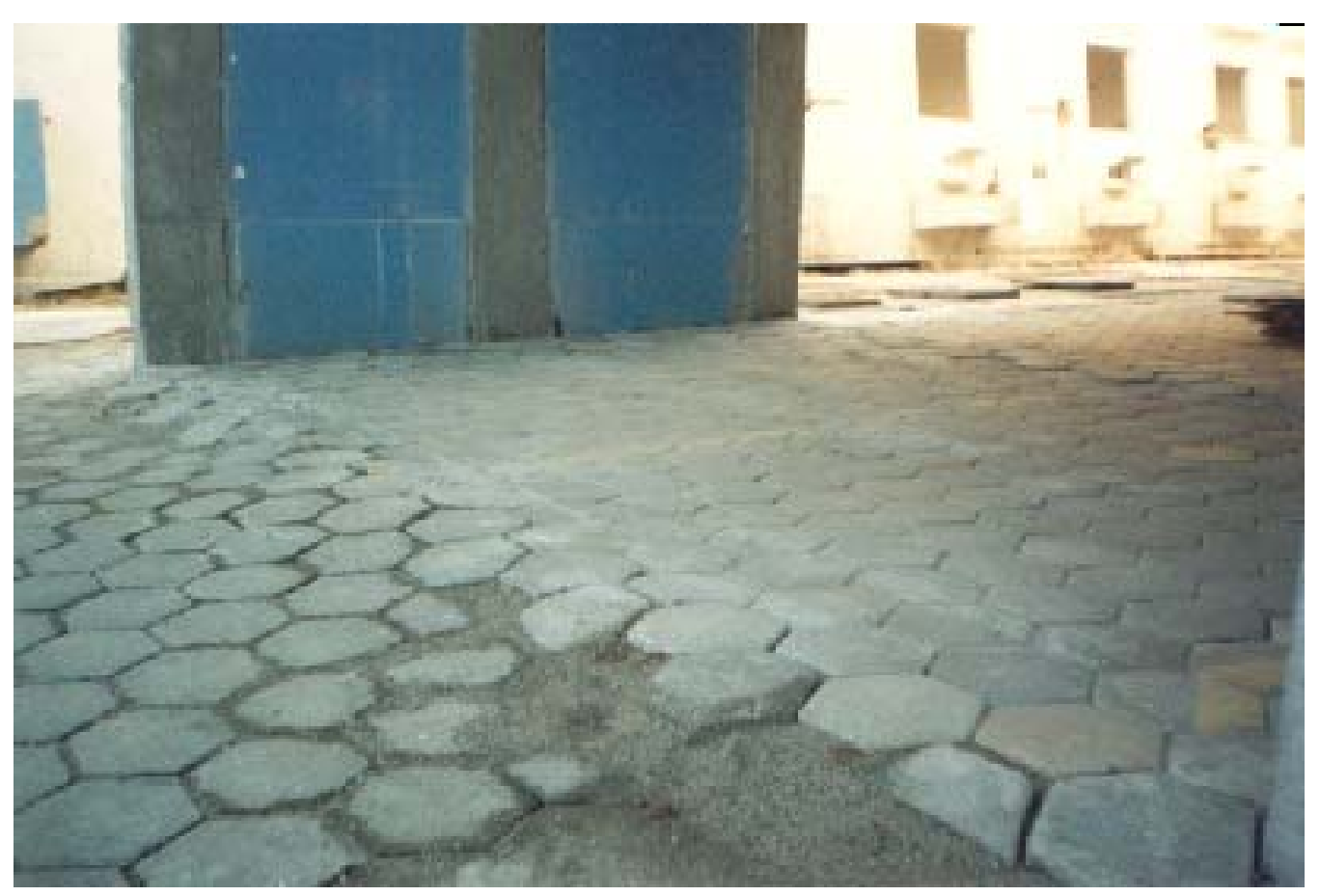

Figura 2.18 - Recalque do piso do estacionamento - Maffei Engenharia. 
A entrega das chaves do residencial ocorreu em março de 2001 e durante o tempo de ocupação, com exceção do piso do estacionamento, os condôminos não observaram quaisquer anomalias estruturais, como trincas em paredes ou lajes, esquadrias de difícil manejo e rupturas anormais de vidraças.

Pela configuração do rompimento da laje de transição, pode-se afirmar que os pilares do térreo localizados próximos ao fundo do terreno, o qual faz divisa com a rua Tainha, cederam sem qualquer restrição ao conjunto do edifício, e não penetraram no interior do primeiro pavimento. Já os pilares da outra face da edificação, por sua vez, não cederam, entretanto puncionaram a laje e penetraram no interior dos apartamentos.

Observa-se na figura 2.19 que o piso do primeiro pavimento está praticamente intacto, inclusive com o acabamento de ardósia, que não sofreu maiores avarias. Já a figura 2.20 mostra o exemplo de um pilar que não cedeu junto com o edifício e acabou penetrando no pavimento superior. Podem ser vistos, na fotografia, os blocos pintados de cor azul, que pertenciam ao pilar parede, e a laje de transição, que está com seus perfis pré-moldados todos retorcidos e à mostra.

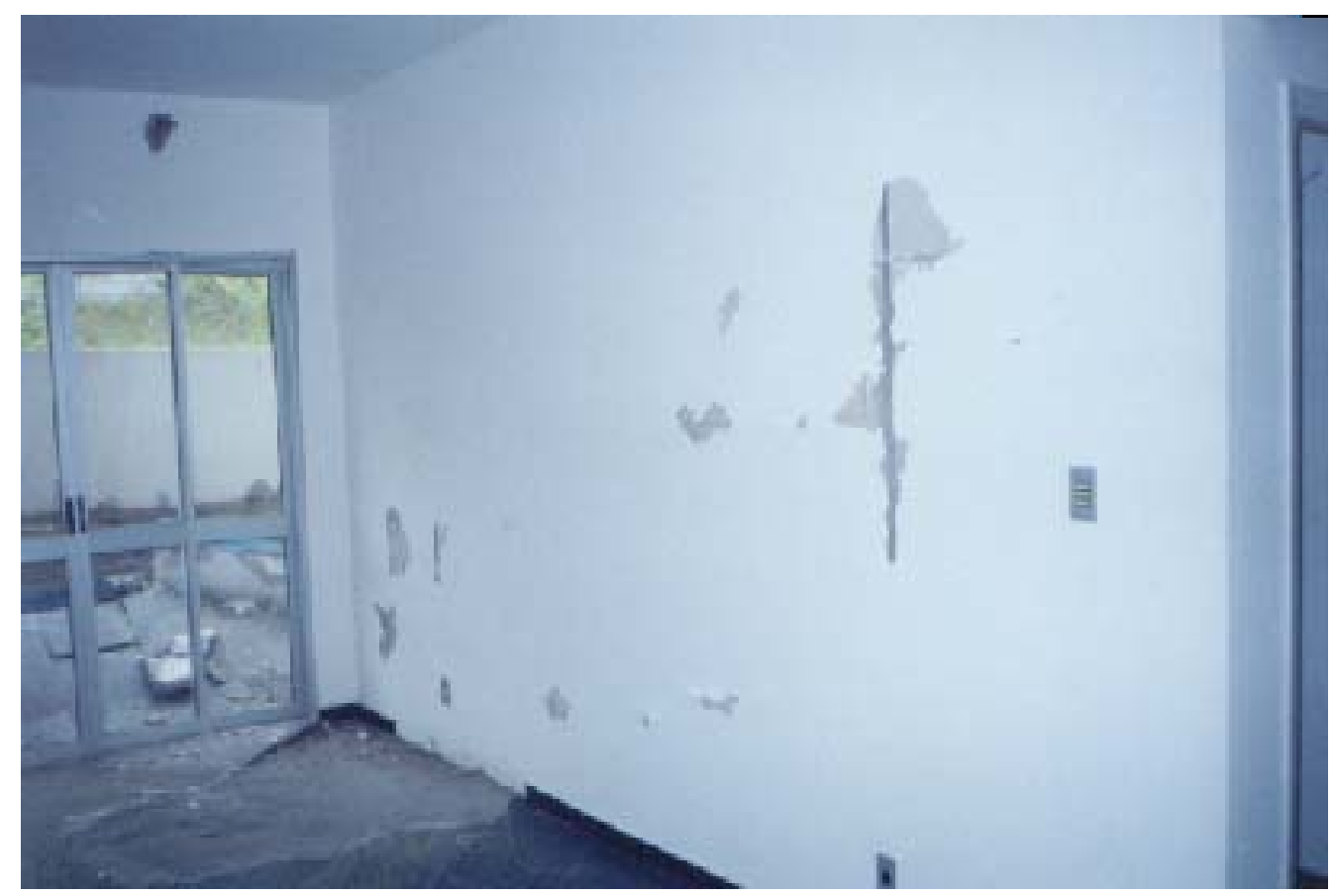

Figura 2.19 - Pilar afundou junto com o edificio - Maffei Engenharia. 


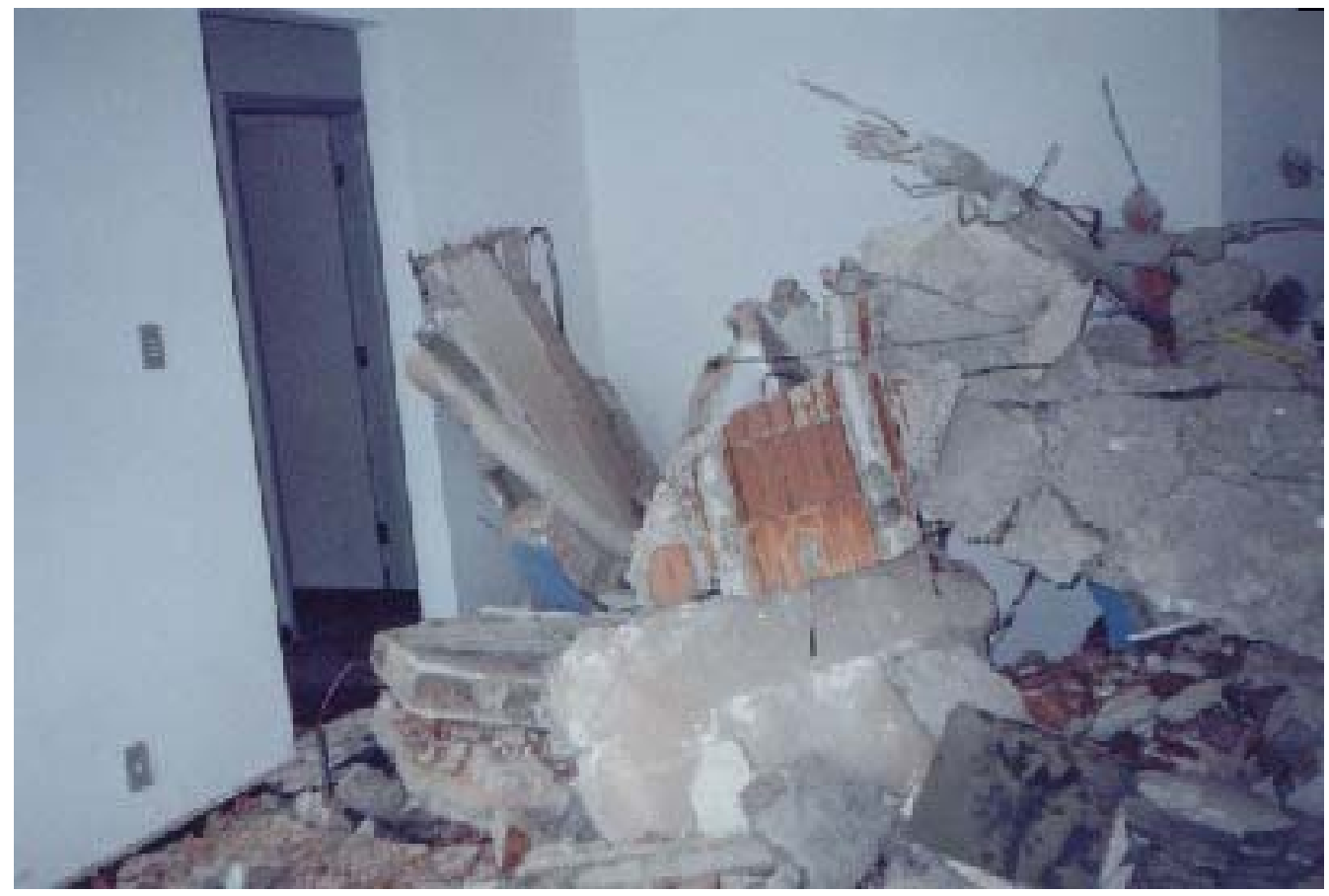

Figura 2.20 - Pilar do térreo no interior do primeiro pavimento.

Ficou bem compreendido, pela configuração dos destroços, que os pilares próximos ao bloco "A" tombaram à medida que o edifício desabou. A figura 2.21 confirma esta constatação e atenta, também, para o grande deslocamento horizontal que o edifício desenvolveu no sentido da rua Tainha (ver também a figura 2.22).

Com o desabamento do edifício, o solo foi demasiadamente comprimido, o que provocou uma expansão lateral de sua massa. Uma prova disso, como mostra a figura 2.23 , foram as rachaduras formadas no muro da divisa do terreno com a rua Tainha.

O solo, após o desabamento, configurou-se de maneira bastante flexível: a forma como ele se acomodou junto à estrutura, em uma primeira análise rudimentar, demonstrou ser um material mole e compressível. 


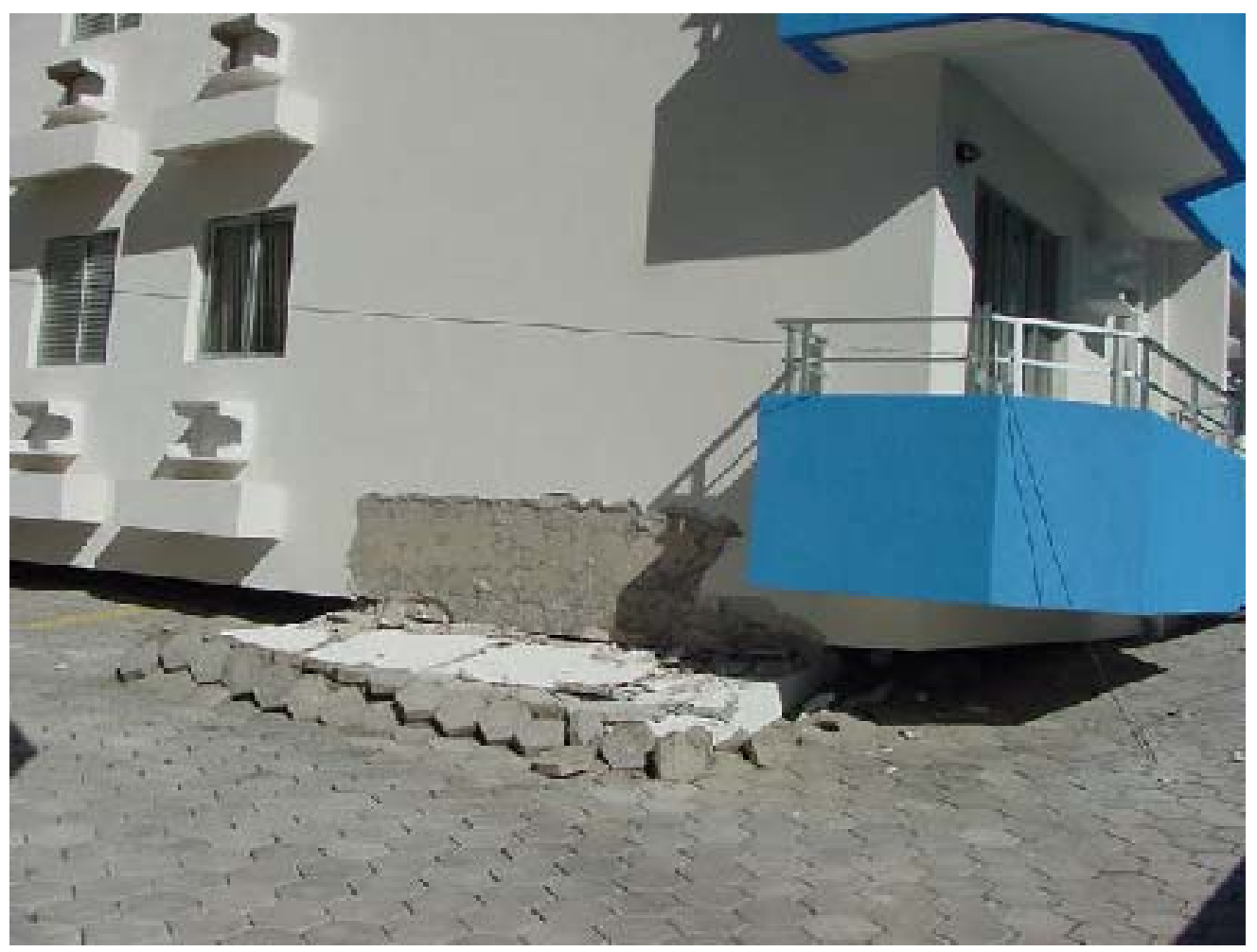

Figura 2.21 - Pilar tombado - Maffei Engenharia.

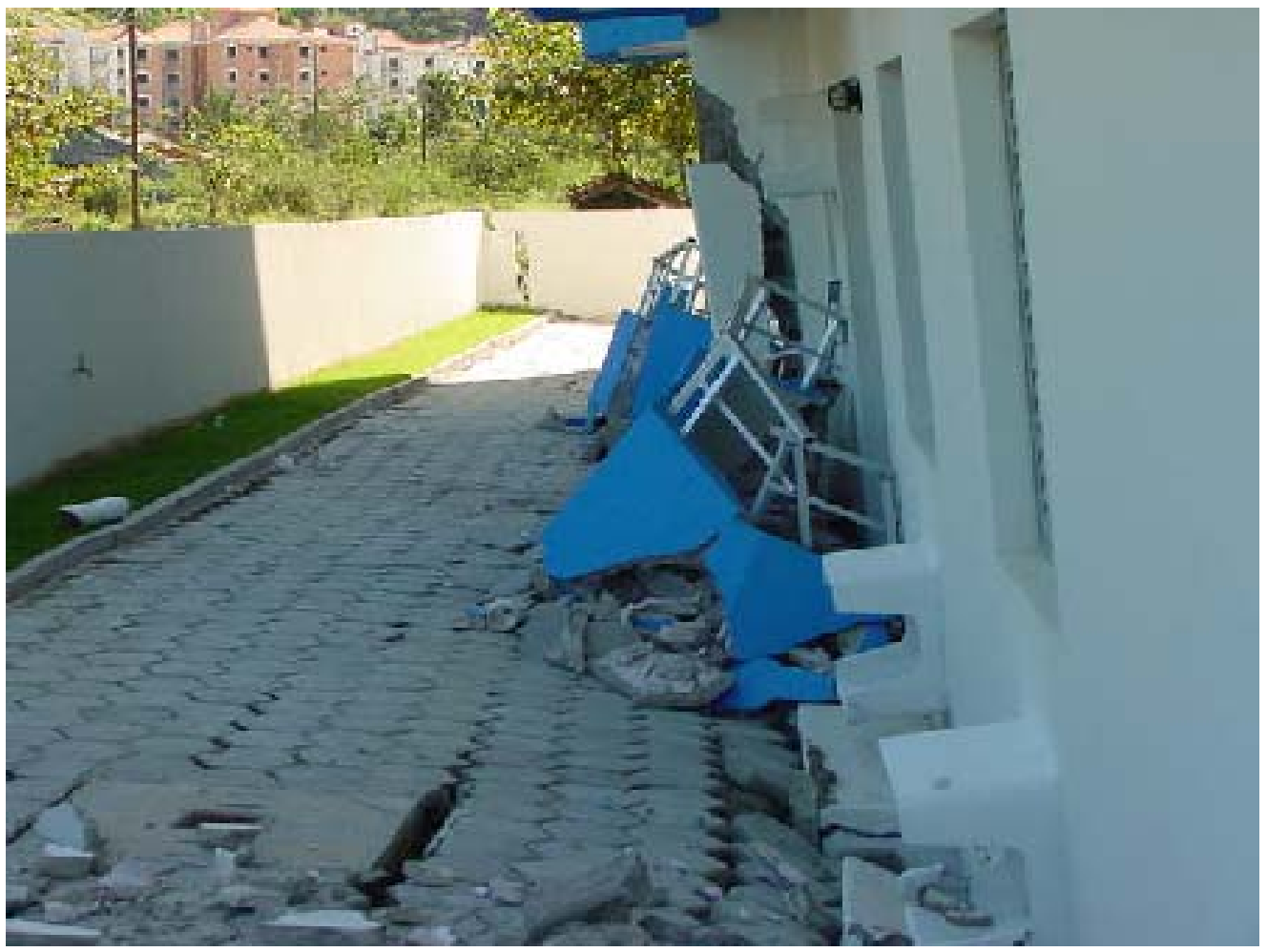

Figura 2.22 - Solo do térreo bastante deformado - Maffei Engenharia. 


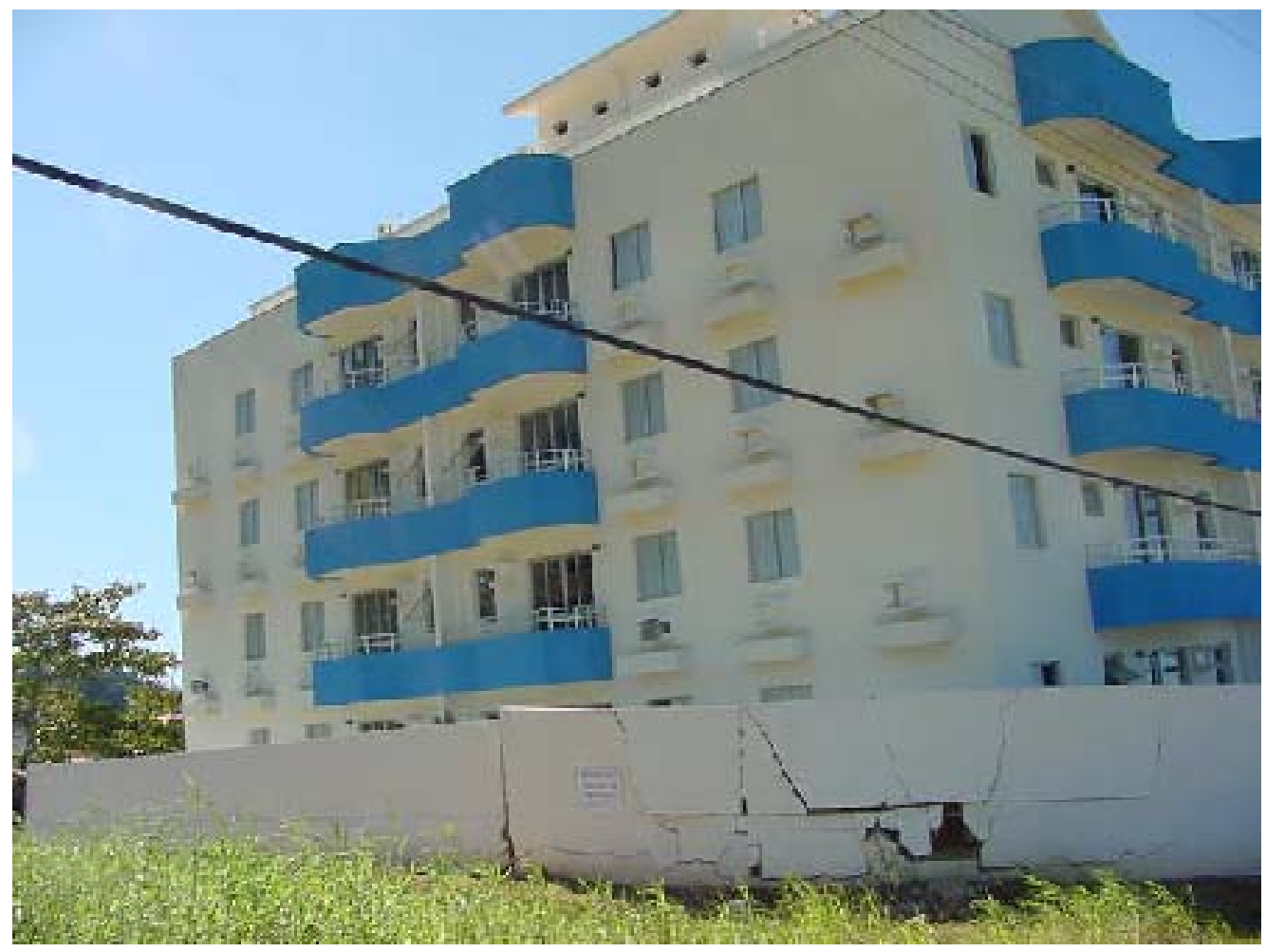

Figura 2.23 - Muro danificado devido à expansão do solo - Maffei Engenharia.

Devido ao perigo iminente de novos desabamentos, a Defesa Civil de Ubatuba, SP, interditou a área dos edifícios, proibiu o acesso do público ao local e um vigia foi contratado pelos condôminos com o intuito de assegurar a integridade patrimonial do condomínio. Tal medida vigorou até a elaboração do laudo técnico oficial, que divulgou as reais condições do edifício desabado, a possibilidade de sua recuperação e os perigos envolvidos nesta operação.

O engenheiro e docente de Estruturas da Escola Politécnica de São Paulo, Dr. Carlos Eduardo Moreira Maffei, realizou, em 19 de maio de 2001, uma vistoria inicial para avaliar as causas do acidente e antever a possibilidade de novas ruínas. A primeira hipótese levantada foi a de que uma suposta ruptura ocorrida nas fundações ocasionou o acidente e, mesmo o bloco "A" estando aparentemente intacto, também poderia estar sujeito ao mesmo tipo de desabamento. 


\section{CAPÍtULO 3}

\section{ESTUDO DAS CAUSAS DO COLAPSO}

\subsection{OBJETIVO DO CAPÍTULO}

O capítulo três tem por objetivo mostrar os agentes responsáveis pelo processo de ruptura da sustentação do bloco "B" do condomínio, que culminou no grande deslocamento observado em sua estrutura.

Para concretizar tal meta, foi desenvolvido um modelo numérico do edifício, com a finalidade de simular a estrutura antes do colapso e determinar as reações de apoio em suas estacas.

É evidente que o assunto abordado está diretamente relacionado com o sistema estrutural da edificação, descrito no capítulo dois, e com as características do solo de fundação, em que ela está apoiada. Portanto, para nortear o atual trabalho com informações pertinentes ao tipo de solo em questão, será feita uma descrição detalhada do material coletado no local do acidente, por meio de sondagens de penetração. Com estas informações, o mecanismo ocorrido na interação soloestrutura pode ser interpretado e, conseqüentemente, identificadas razões pelas quais ocorreu o sinistro. 


\subsection{REVISÃO BIBLIOGRÁFICA}

A revisão bibliográfica apresentada neste item procura, de maneira simplificada, abordar assuntos relevantes ao tema, restringindo-se somente ao comportamento do tipo de solo encontrado no terreno do condomínio.

\subsubsection{ESTUDO DOS SOLOS DA BAIXADA SANTISTA}

Casos de solos similares ao encontrado no terreno do condomínio em estudo, o qual está detalhado no item 3.3.2, já foram amplamente pesquisados na Baixada Santista. Essa região localiza-se sobre um subsolo constituído por sedimentos quaternários, cujo perfil geológico da orla consiste na alternância entre camadas de areia e camadas de argila orgânica. Esse pacote de solos está assentado sobre um maciço cristalino, formado por rochas de gnaisse e de granito (TEIXEIRA, 1994 apud REIS 2000).

Segundo TEIXEIRA (1994) ${ }^{1}$ apud REIS (2000), todas as sondagens e investigações realizadas na cidade de Santos resultaram em argilas classificadas como muito moles, mas que apresentaram resistências à compressão simples entre 60 $\mathrm{kN} / \mathrm{m}^{2}$ a $150 \mathrm{kN} / \mathrm{m}^{2}$, faixa de resistência de argilas médias a rijas. Este fato poderia induzir engenheiros de fundações a, erroneamente, concluir estar lidando com materiais de pouca compressibilidade.

MASSAD (1994) ${ }^{2}$ apud REIS (2000) avalia as propriedades físicas das argilas sedimentares formadas na Baixada Santista. Defende que, devido às oscilações do nível do mar, ocorreram pelo menos duas seqüências de sedimentação, que deram origem a dois tipos de sedimentos argilosos - Holocênicos e Pleistocênicos -, com propriedades geotécnicas distintas.

Os Holocênicos são constituídos de argilas com sedimentos fluviolagunares, formados há 7000 anos, com $\mathrm{N}_{\text {spt }}$ de 0 a 2, levemente sobre-adensado.

\footnotetext{
${ }^{1}$ TEIXEIRA, A. H. (1994). "Fundações rasas na baixada santista”. Solos do Litoral de São Paulo. ABMS/NRSP. Páginas 137-154

2 MASSAD, F. (1994) "Propriedades dos sedimentos marinhos". Solos do Litoral de São Paulo. ABMS/NRSP
} 
Os sedimentos Pleistocênicos ocorrem abaixo dos Holocênicos e são constituídos de camadas de areia com $6 \mathrm{~m}$ a $7 \mathrm{~m}$ de espessura, e camada de argilas média a rija, situadas geralmente a uma profundidade de $20 \mathrm{~m}$ a $25 \mathrm{~m}$.

Apesar da aparente semelhança entre as argilas estudadas na cidade de Santos e as encontradas pelas sondagens realizadas no condomínio "Anêmona", é importante ressaltar que pode existir, entre os dois materiais, muitas variações em suas propriedades.

GONÇALVES (1994) ${ }^{3}$ apud REIS (2000), ao realizar ensaios das argilas da COSIPA, em Cubatão, encontrou valores de índice de compressão, índice de vazios e tensão de pré-adensamento completamente diferentes dos resultados verificados por TEIXEIRA (1994) ${ }^{4}$ apud REIS (2000), na cidade de Santos, muito embora as duas cidades estejam próximas.

\subsubsection{CLASSIFICAÇÃO DOS SOLOS FINOS}

Quando a porcentagem do volume do solo que passa pela peneira № 200 é superior a $50 \%$ (ou $35 \%$ no sistema rodoviário), ele é considerado um solo fino, classificado como argila ou silte.

$\mathrm{Na}$ prática da engenharia de fundações, a distinção entre solos argilosos e siltosos é feita por inspeção táctil-visual. Materiais considerados argilosos comportam-se, quando na presença de água, de maneira bastante plástica, e formam torrões duros ao se secar. Os solos são classificados como siltosos quando são mais suaves para serem manuseados na presença de água e, quando secos, se esfarelam com facilidade.

ATTERBERG (1911) propôs e CASAGRANDE (1932) adaptou, para a mecânica dos solos, procedimentos para definir teores de umidade ocorridos na mudança dos estados físicos do solo. Deste modo, as argilas podem ser classificadas

\footnotetext{
${ }^{3}$ GONÇALVES, H. H. S. (1994) “Análise, através de modelos visco-elástico, dos ensaios de laboratório, para previsão dos recalques de uma argila". Solos e rochas. Vol 17, No. 1. Abril 1994. p. 3-12.

4 TEIXEIRA, A. H. (1994). "Fundações rasas na baixada santista”. Solos do Litoral de São Paulo. ABMS/NRSP. Páginas 137-154
} 
como: líquidas, quando estiverem submetidas a muita umidade; plásticas; semisólidas e sólidas, na medida que o teor de umidade for reduzido. A figura 3.1 mostra esta variação de consistência do solo, em função do teor de umidade.

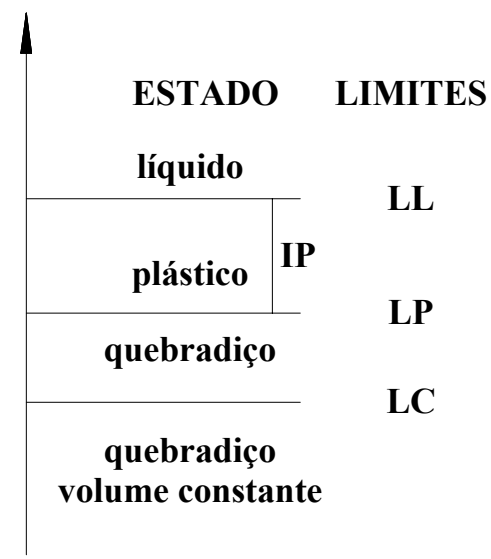

Figura 3.1 - Diferentes estados físicos do solo - Pinto (1998).

$\mathrm{O}$ indice de plasticidade (IP) do solo é determinado observando-se a faixa pelo qual o solo comporta-se plasticamente. Numericamente, o valor do índice de plasticidade é obtido subtraindo-se o limite de liquidez $(L L)$ do limite de plasticidade $(L P)$. Estes limites são muito importantes, pois são usados em vários tipos de solos, para caracterizá-los quanto às suas propriedades de deformabilidade e de resistência (tabela 3.1).

Tabela 3.1 Valores típicos de limites de Atteberg de alguns solos brasileiros - Pinto (1998).

\begin{tabular}{ccc}
\hline Solos & LL & IP \\
\hline Arenoso fino, laterítico (a) & 29 & 11 \\
Arenoso fino, laterítico (b) & 44 & 13 \\
Solos de basalto, laterítico & 43 & 16 \\
Solo saprolítico de gnaisse & 48 & 16 \\
Solo saprolítico de granito & 48 & 16 \\
Argila orgánica de várzeas quaternárias & 70 & 30 \\
Argilas orgânicas de baixadas litorâneas & 120 & 60 \\
\hline
\end{tabular}


Os procedimentos empregados na determinação desses limites fogem do escopo deste trabalho, no entanto, eles podem ser encontrados nas Normas Brasileiras MB-30, MB-31 e MB-55 da ABNT.

A consistência das argilas apresentadas na tabela 3.2 foram definidas por TERZAGHI E PECK (1948), em função da sua resistência à compressão simples.

Tabela 3.2 Consistência das argilas em função da resistência à compressão - Pinto (1998).

\begin{tabular}{cc}
\hline Consistência & Resistencia à compressão simples \\
\hline Muito mole & $<25$ \\
Mole & $25-50$ \\
Consistência média & $50-100$ \\
Rija & $100-200$ \\
Muito rija & $200-400$ \\
Dura & $>400$ \\
\hline
\end{tabular}

\subsubsection{DEFORMAÇÃO AO LONGO DO TEMPO - ADENSAMENTO}

As argilas possuem baixa permeabilidade, se comparadas com as areias. Isto as diferencia, pois aquelas não são capazes de dissipar rapidamente as pressões neutras, oriundas de quaisquer solicitações que ajam sobre elas.

Com o objetivo de simplificar o entendimento das deformações das argilas, costuma-se dividi-las em duas fases: primárias e secundárias.

a) Deformações primárias são as que ocorrem devido à expulsão de água dos espaços vazios do material, e, em virtude de sua baixa permeabilidade, este processo demanda de um tempo mais prolongado se comparado com solos arenosos.

A analogia proposta por TERZAGHI (1923) foi bastante difundida como modelo de previsão do adensamento primário, ocorrido em solos saturados. Neste modelo, o solo assemelha-se a uma mola que suporta um êmbolo com uma válvula. Este êmbolo, por sua vez, localiza-se confinado em um pistão cheio de água (figura 3.2). Ao se aplicar um carregamento no sistema, inicialmente toda a solicitação será suportada pela água. À medida que a vazão pela válvula superior começar a se concretizar, o que caracterizará a expulsão da água do material, as ações serão 
gradativamente transferidas para a mola. No momento final, cessará o fluxo de água na válvula e todo o peso aplicado estará sendo suportado pela mola.
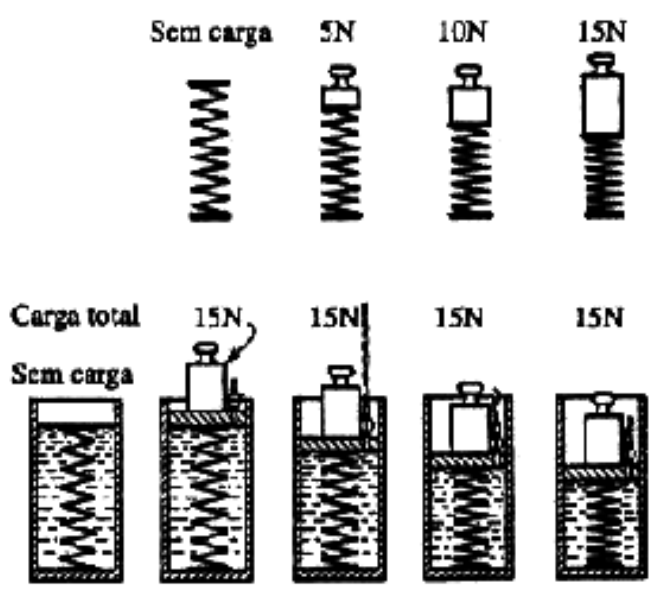

$\begin{array}{lccccc}\begin{array}{l}\text { Carga suporlada } \\ \text { pela igua }\end{array} & 0 & 15 & 10 & 5 & 0 \\ \begin{array}{l}\text { Carga suportada } \\ \text { pela mole }\end{array} & 0 & 0 & 5 & 10 & 15 \\ \begin{array}{l}\text { Porcentagem de } \\ \text { adensamento }\end{array} & & 0 & 33 & 67 & 100\end{array}$

Figura 3.2 - Adensamento do solo análogo a um conjunto de mola e êmbolo carregado - Pinto (1998).

b) Deformações secundárias são as que ocorrem depois de todas as pressões neutras terem sido dissipadas. Elas são observadas em todos os materiais, no entanto são mais perceptíveis nos solos. Sabe-se que a água desempenha papel fundamental na ligação entre os minerais de argila. Na medida que algumas dessas ligações são destruídas por expulsão da água adsorvida no local, as forças são transmitidas para contatos vizinhos e, devido ao acréscimo de carregamento, estes rearranjos são acompanhados de pequenos deslocamentos figura 3.3. 

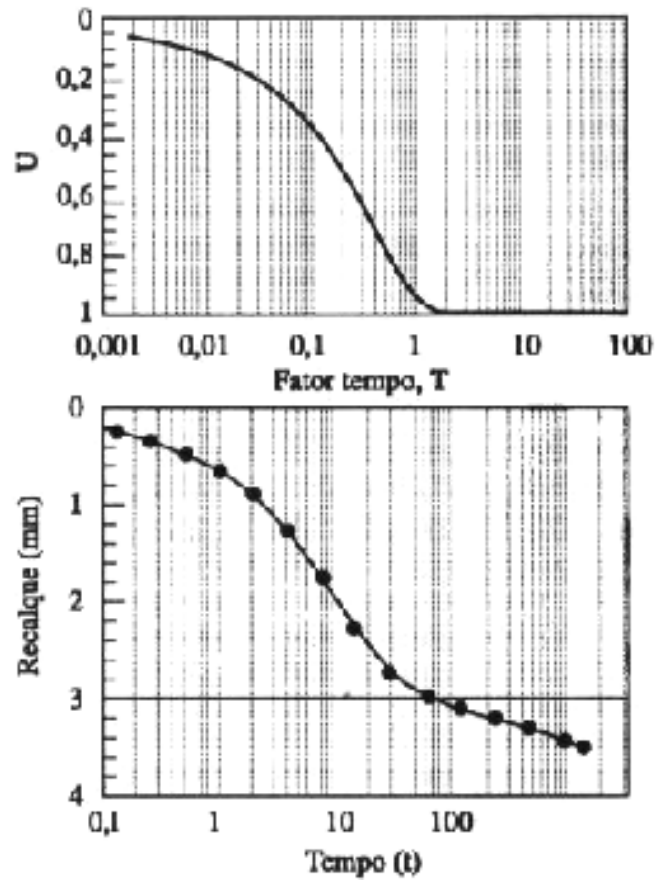

Figura 3.3 - Adensamento ocorrido após dissipação da pressão neutra - Pinto (1998).

\subsubsection{TENSÃO NO SOLO E EMPUXO}

Como indicado na figura 3.4, que quando se aplica um carregamento em um solo saturado, considera-se que a tensão efetiva $\left(\sigma^{\prime}\right)$ nas partículas de sua estrutura é a tensão total $(\sigma)$, a que ele está submetido, subtraída pela pressão neutra (u), devida à compressão da água existente no interior do material. Aplicando-se a analogia de Terzaghi, a tensão efetiva $(\sigma ')$ no solo é análoga à força exercida pela mola para sustentar o êmbolo carregado, como mostrado na figura 3.2.

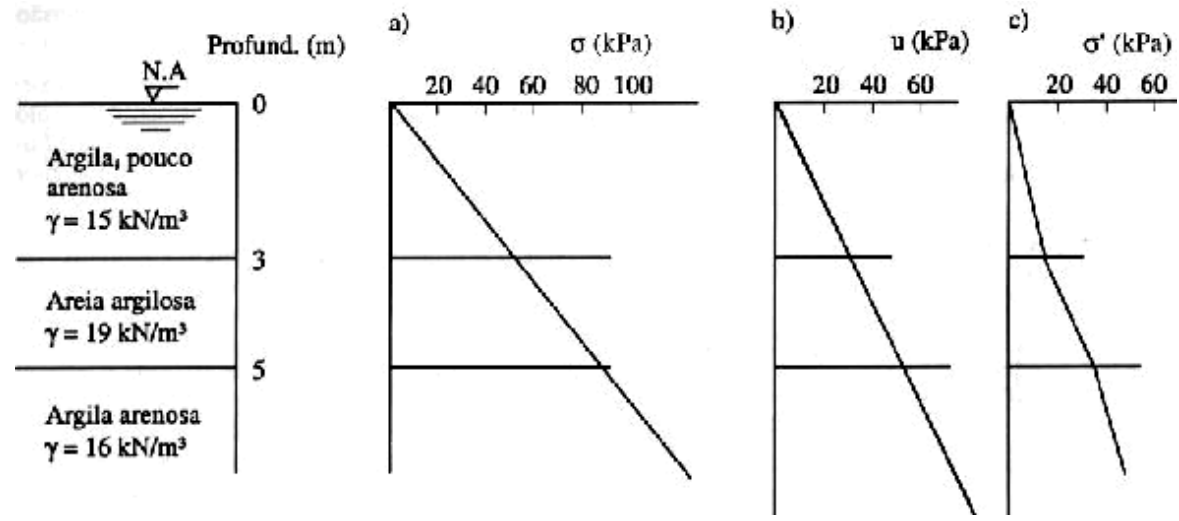

Figura 3.4 - Tensão total, pressão neutra e tensão efetiva ao longo do perfil do solo - Pinto (1998). 
Tomando-se como base um plano horizontal situado no interior de um perfil geológico, deduz-se que, se o terreno não for inclinado, a tensão cisalhante neste plano é nula, porque os efeitos se equilibram nas diversas direções. Pode-se dizer que, por analogia, o mesmo ocorre em planos verticais.

A tensão horizontal gerada em um corte vertical do perfil geológico depende da constituição do solo e do histórico de tensões a que ele esteve submetido anteriormente. Normalmente esta tensão está correlacionada à tensão vertical exercida. A relação entre estes dois valores é denominada coeficiente de empuxo em repouso $\left(K_{0}\right)$.

Ao se acrescentar carregamento no solo, podendo ser ele devido à implantação de um aterro ou descarregamento de um elemento de fundação, a tensão vertical num plano horizontal, situado dentro do solo, aumenta de valor igual ao carregamento. Não se pode inferir o mesmo em relação às tensões horizontais, as quais, devido ao atrito entre as partículas, não possuem um acréscimo tão grande.

O coeficiente de empuxo $\left(K_{0}\right)$, medido em solos arenosos, situa-se entre 0,4 e 0,5 e, em solos argilosos, entre 0,5 e 0,8 . Conclui-se que, exceto em alguns casos, o valor de $\mathrm{K}_{0}$ será sempre menor que a unidade. Para diferentes tipos de solos, a relação entre as tensões horizontais e as verticais pode ser estimada pela plasticidade do material ou por seu ângulo efetivo de atrito interno (figura 3.5).
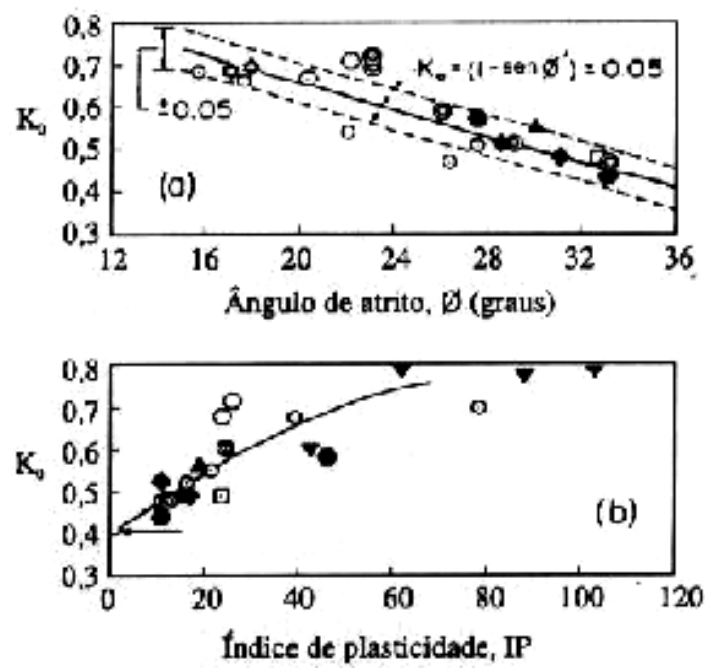

Figura 3.5 - $K_{0}$ em função do ângulo de atrito e IP - Pinto (1998). 
O subsolo de um determinado terreno não está sujeito apenas ao acréscimo de tensões, podendo ser descarregado. Geralmente esse alívio de tensões ocorre por remoção de camadas superficiais do solo e ela pode ser mecânica ou determinada por fatores naturais, tais como a erosão.

À medida que é aliviado o peso atuante no solo, as tensões verticais são reduzidas, na mesma magnitude. Para as tensões horizontais, não se verifica o mesmo comportamento, devido à mobilização do atrito entre as partículas, as quais atuam no sentido contrário ao da formação do solo. Deste modo, o valor de $\mathrm{K}_{0}$ é maior do que nas faixas descritas, podendo, inclusive, ser superior a um.

\subsubsection{INVESTIGAÇÕES GEOTÉCNICAS}

O reconhecimento das condições do subsolo constitui-se em requisito para projetos de fundações seguros e econômicos. No Brasil, o custo envolvido na execução de sondagens de reconhecimento varia, normalmente, entre 0,2 e $0,5 \%$ do custo total da obra.

É importante ter ciência de que cada método de sondagem está associado ao parâmetro que se deseja investigar. A título de exemplo, pode-se citar o SPT, que é particularmente adequado à prospecção de solos granulares e à previsão de valores do ângulo de atrito interno - no entanto, não será utilizado com sucesso na previsão da resistência não-drenada, de depósitos de argilas moles. Ensaios de palheta e de piezocones devem ser adotados para esta finalidade.

A programação de sondagens deve satisfazer a exigências mínimas, que garantam o reconhecimento das condições do subsolo. A Norma Brasileira NBR 8036 regulamenta tais exigências, apresentando recomendações quanto ao número, localização e profundidade de sondagens de simples reconhecimento. A profundidade atingida nas sondagens deve assegurar o reconhecimento das características do solo solicitado pelos elementos de fundações.

Novos equipamentos de investigação foram introduzidos nas últimas décadas, visando ampliar o uso de diferentes tecnologias a diferentes condições de subsolo. Um resumo das técnicas de ensaios de campo e suas aplicações, como as adotadas na prática internacional, é apresentado na Tabela 3.3. 
Tabela 3.3 Aplicabilidade e uso de ensaios “in situ” - Lunne et al. (1997).

\begin{tabular}{|c|c|c|c|c|c|c|c|c|c|c|c|c|c|c|}
\hline & & \multicolumn{13}{|c|}{ Parâmetros } \\
\hline Grupo & Equipamento & Tipo & Perfil & $\mathrm{u}$ & $f^{\prime}$ & $\mathrm{S}_{\mathrm{u}}$ & $\mathrm{D}_{\mathrm{r}}$ & $\mathrm{m}_{\mathrm{v}}$ & $\mathrm{C}_{\mathrm{v}}$ & $\mathrm{K}$ & $\mathrm{G}_{0}$ & $\mathrm{~S}_{\mathrm{h}}$ & OCR & s -e \\
\hline \multirow[t]{8}{*}{ Penetrômetro } & Dinâmicos & $\mathrm{C}$ & B & - & $\mathrm{C}$ & $\mathrm{C}$ & $\mathrm{C}$ & - & - & - & $\mathrm{C}$ & - & $\mathrm{C}$ & - \\
\hline & Mecânicos & B & $\mathrm{A} / \mathrm{B}$ & - & $\mathrm{C}$ & $\mathrm{C}$ & B & $\mathrm{C}$ & - & - & $\mathrm{C}$ & $\mathrm{C}$ & $\mathrm{C}$ & - \\
\hline & Elétricos (CPT) & B & A & - & $\mathrm{C}$ & B & $\mathrm{A} / \mathrm{B}$ & $\mathrm{C}$ & - & - & $\mathrm{B}$ & $\mathrm{B} / \mathrm{C}$ & B & - \\
\hline & Piezocone & A & A & A & $\mathrm{B}$ & B & $\mathrm{A} / \mathrm{B}$ & $\mathrm{B}$ & $\mathrm{A} / \mathrm{B}$ & B & $\mathrm{B}$ & $\mathrm{B} / \mathrm{C}$ & B & $\mathrm{C}$ \\
\hline & Sísmicos & A & A & A & $\mathrm{B}$ & $\mathrm{A} / \mathrm{B}$ & $\mathrm{A} / \mathrm{B}$ & $\mathrm{B}$ & $\mathrm{A} / \mathrm{B}$ & $\mathrm{B}$ & $\mathrm{A}$ & B & $\mathrm{B}$ & $\mathrm{B}$ \\
\hline & Dilatômetro & B & A & $\mathrm{C}$ & $\mathrm{B}$ & B & $\mathrm{C}$ & $\mathrm{B}$ & - & - & $\mathrm{B}$ & B & $\mathrm{B}$ & $\mathrm{C}$ \\
\hline & Standart & A & B & - & $\mathrm{C}$ & $\mathrm{C}$ & B & - & - & - & $\mathrm{C}$ & - & $\mathrm{C}$ & - \\
\hline & Resistividade & B & B & - & $\mathrm{B}$ & $\mathrm{C}$ & A & $\mathrm{C}$ & - & - & - & - & - & - \\
\hline \multirow[t]{3}{*}{ Pressiômetro } & Pré-furo (PBP) & B & $\mathrm{B}$ & - & $\mathrm{C}$ & B & $\mathrm{C}$ & $\mathrm{B}$ & $\mathrm{C}$ & - & $\mathrm{B}$ & $\mathrm{C}$ & $\mathrm{C}$ & $\mathrm{C}$ \\
\hline & Auto-perfurante & $\mathrm{B}$ & B & A & B & B & B & $\mathrm{B}$ & $\mathrm{A}$ & $\mathrm{B}$ & A & $\mathrm{A} / \mathrm{B}$ & B & $\mathrm{A} / \mathrm{B}$ \\
\hline & Cone- & B & $\mathrm{B}$ & - & $\mathrm{C}$ & B & $\mathrm{C}$ & $\mathrm{C}$ & $\mathrm{C}$ & - & $\mathrm{A}$ & $\mathrm{C}$ & $\mathrm{C}$ & $\mathrm{C}$ \\
\hline \multirow[t]{6}{*}{ Outros } & Palheta & B & $\mathrm{C}$ & - & - & A & - & - & - & - & - & - & $\mathrm{B} / \mathrm{C}$ & B \\
\hline & Ensaio de placa & $\mathrm{C}$ & - & - & $\mathrm{C}$ & B & B & $\mathrm{B}$ & $\mathrm{C}$ & $\mathrm{C}$ & A & $\mathrm{C}$ & B & B \\
\hline & Placa heliciodal & $\mathrm{C}$ & $\mathrm{C}$ & - & $\mathrm{C}$ & B & B & B & $\mathrm{C}$ & $\mathrm{C}$ & A & $\mathrm{C}$ & B & - \\
\hline & Permeabilidade & $\mathrm{C}$ & - & A & - & - & - & - & $\mathrm{B}$ & A & - & - & - & - \\
\hline & Ruptura & - & - & $\mathrm{B}$ & - & - & - & - & $\mathrm{C}$ & $\mathrm{C}$ & - & B & - & - \\
\hline & Sísmicos & $\mathrm{C}$ & $\mathrm{C}$ & - & - & - & - & - & - & - & A & - & B & - \\
\hline
\end{tabular}

Aplicabilidade: $\mathbf{A}=$ alta $; \mathbf{B}=$ moderada; $\mathbf{C}=$ baixa $;-=$ inexistente

Definição de parâmetros:

$\mathbf{u}=$ poro pressão in situ;

f' = ângulo efetivo de atrito;

$\mathbf{S}_{\mathbf{u}}=$ resistência não-drenada ao cisalhamento;

$\mathbf{m}_{\mathbf{v}}=$ módulo restritivo;

$\mathbf{c}_{\mathbf{v}}=$ coeficiente de consolidação;

$\mathbf{K}=$ coeficiente de permeabilidade;

$\mathbf{D}_{\mathbf{r}}=$ densidade;

$\mathbf{G}_{\mathbf{0}}=$ módulo cisalhante a pequenas deformações;

$\mathbf{S}_{\mathbf{h}}=$ tensão horizontal;

$\mathbf{O C R}=$ razão de pré-adensamento;

$\mathbf{s}$ - e = relação tensão-deformação.

$\mathrm{O}$ enfoque deste trabalho restringe-se aos procedimentos de investigações geotécnicas, realizados no terreno do condomínio. Por isso será sucintamente 
descrito, neste item, o teste SPT (Standard Penetration Test), realizado para reconhecer o solo de fundação do local.

A sondagem à percussão com penetração dinâmica (SPT) consiste basicamente na cravação de um amostrador padrão no solo, através da queda livre de um peso de $65 \mathrm{~kg}$ (martelo), que cai de uma altura de $75 \mathrm{~cm}$.

Para iniciar a sondagem, monta-se sobre o terreno, na posição de cada perfuração, um cavalete de quatro pernas. Através de um conjunto de roldanas e de cabos, o peso é orientado sobre o amostrador e solto em queda livre, à altura estipulada.

Geralmente, o primeiro metro de perfuração é executado com trado cavadeira e, os metros subseqüentes, da maneira apresentada no parágrafo anterior.

Conta-se o número de quedas do martelo para a cravação de cada segmento de $15 \mathrm{~cm}$, do total de $45 \mathrm{~cm}$. A soma do número de golpes necessário à penetração do amostrador nos últimos $30 \mathrm{~cm}$ é designada por N. Quando o amostrador é retirado do furo, a amostra contida em sua extremidade é então recolhida e acondicionada, para posterior determinação da composição do solo.

Prossegue-se a abertura do furo com trado helicoidal até a cota de $2 \mathrm{~m} \mathrm{ou}$, quando não for possível o uso do trado, a abertura é feita com auxílio de circulação de água.

Da maneira ora descrita, a sondagem avança até a profundidade desejada e obtém-se, a cada metro perfurado, a resistência e a composição do perfil geológico. O amostrador utilizado nesse teste está detalhado pela Norma Brasileira NBR 6484. 


\subsection{SOLO DE FUNDAÇÃO DO TERRENO}

No sentido de diagnosticar o exato motivo que causou a ruptura da base de sustentação do bloco "B", verificou-se a necessidade de se caracterizar, detalhadamente, o solo de fundação, no qual todas as forças envolvidas estavam sendo descarregadas. Para tanto, foram realizados testes do tipo SPT no terreno do condomínio, com o objetivo de avaliar sua capacidade de suporte, tipo de solo perfurado e nível da água.

As sondagens foram efetuadas pela empresa Túzzolo Engenharia de Sondagens Ltda. especializada no assunto, de maneira a assegurar qualidade e representatividade nos resultados obtidos.

Para caracterizar o solo da fundação, a empresa realizou quatro sondagens, sendo três delas próximas à frente do terreno e uma posicionada na Rua Tainha, que faz divisa com o fundo do condomínio. A figura 3.6 mostra os locais onde foram realizadas as investigações.

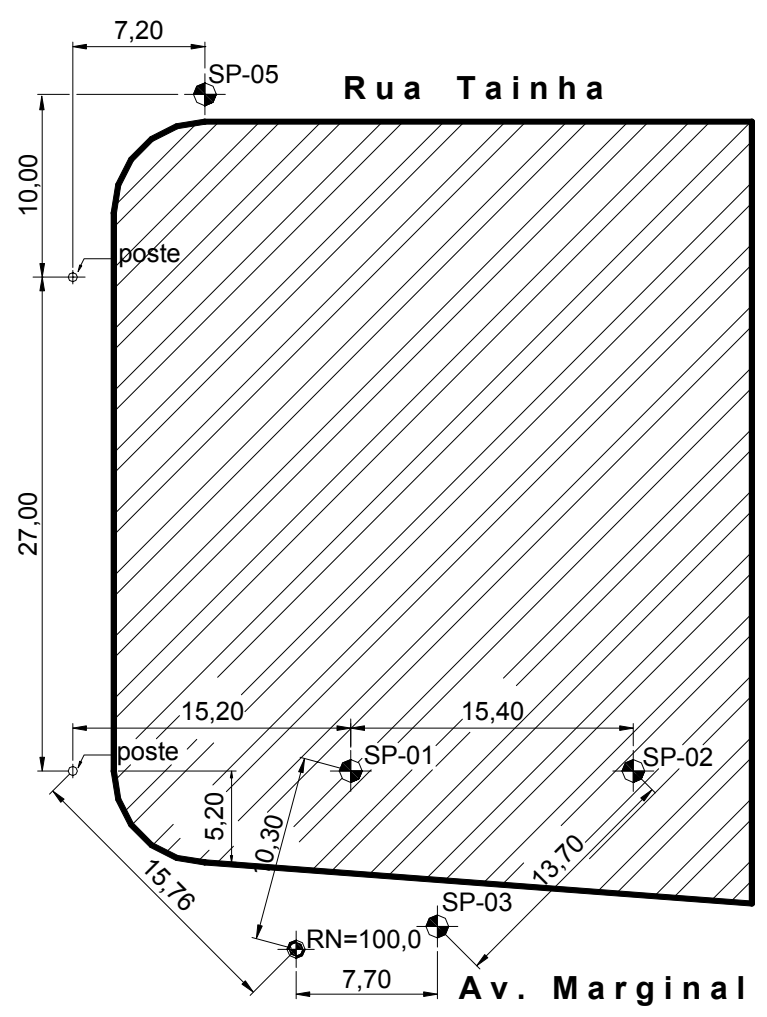

Figura 3.6 - Posições onde foram realizadas as sondagens - Túzzolo Engenharia. 
As figuras $3.7,3.8,3.9$ e 3.10 apresentam os resultados obtidos nas sondagens e a figura 3.11 ilustra o subsolo visto em corte.

Figura 3.7 - Sondagem SP 01 - Túzzolo Engenharia. 


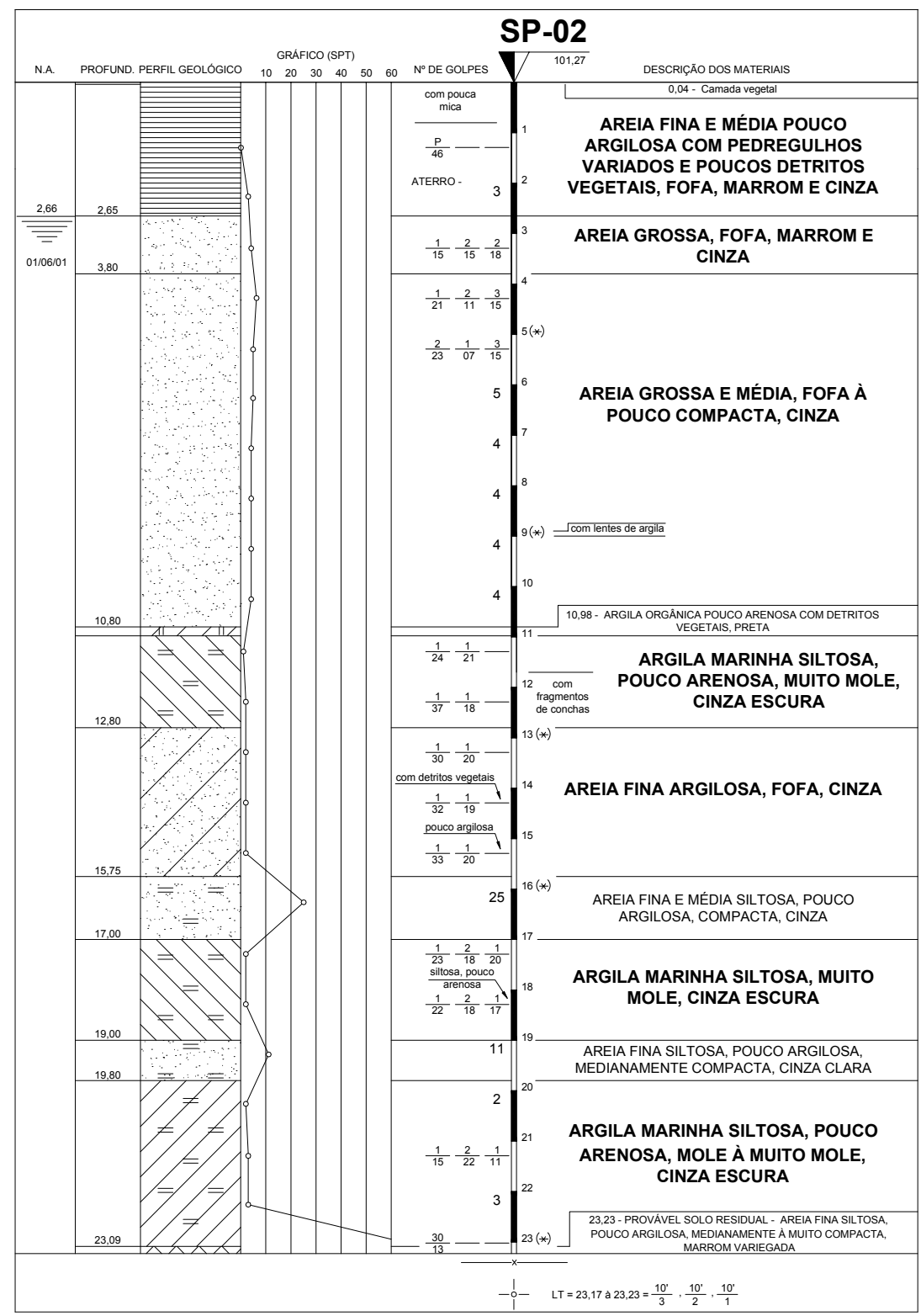

Figura 3.8 - Sondagem SP 02 - Túzzolo Engenharia. 


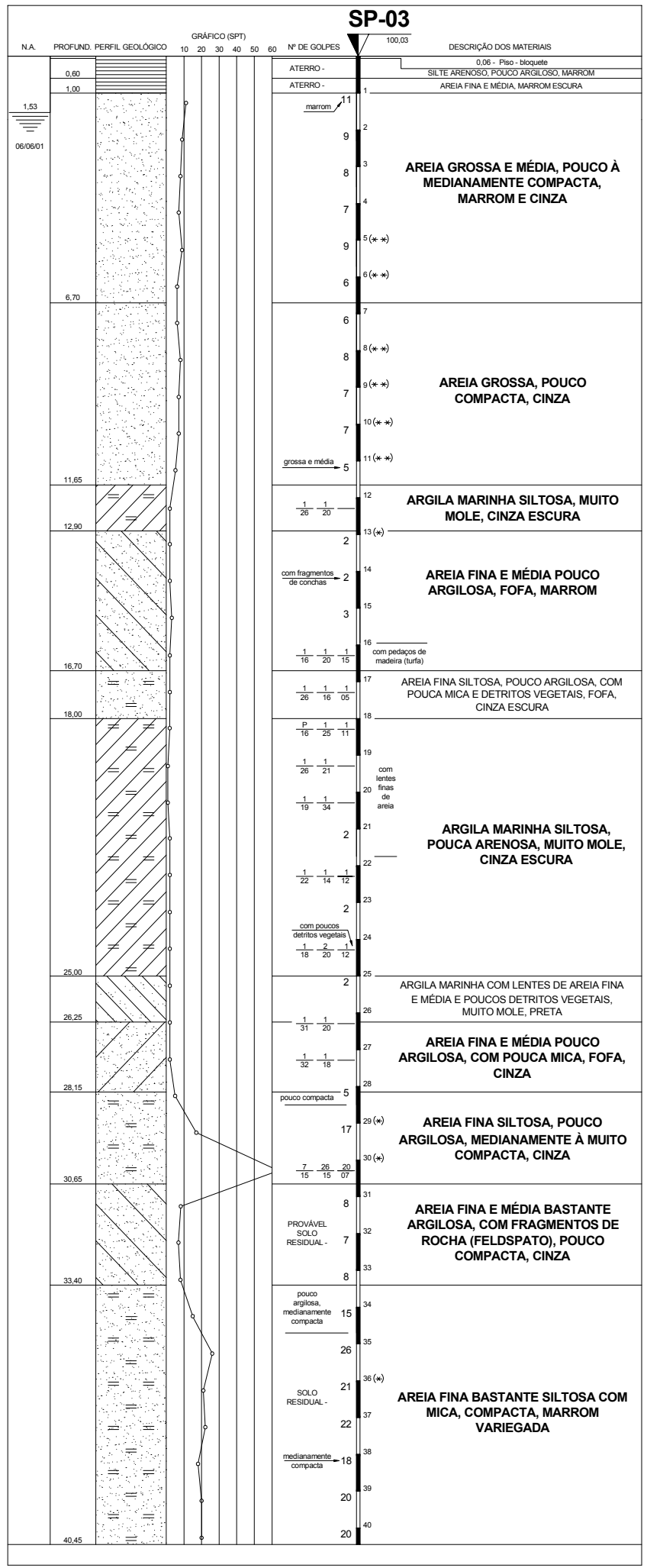

Figura 3.9 - Sondagem SP 03 - Túzzolo Engenharia. 


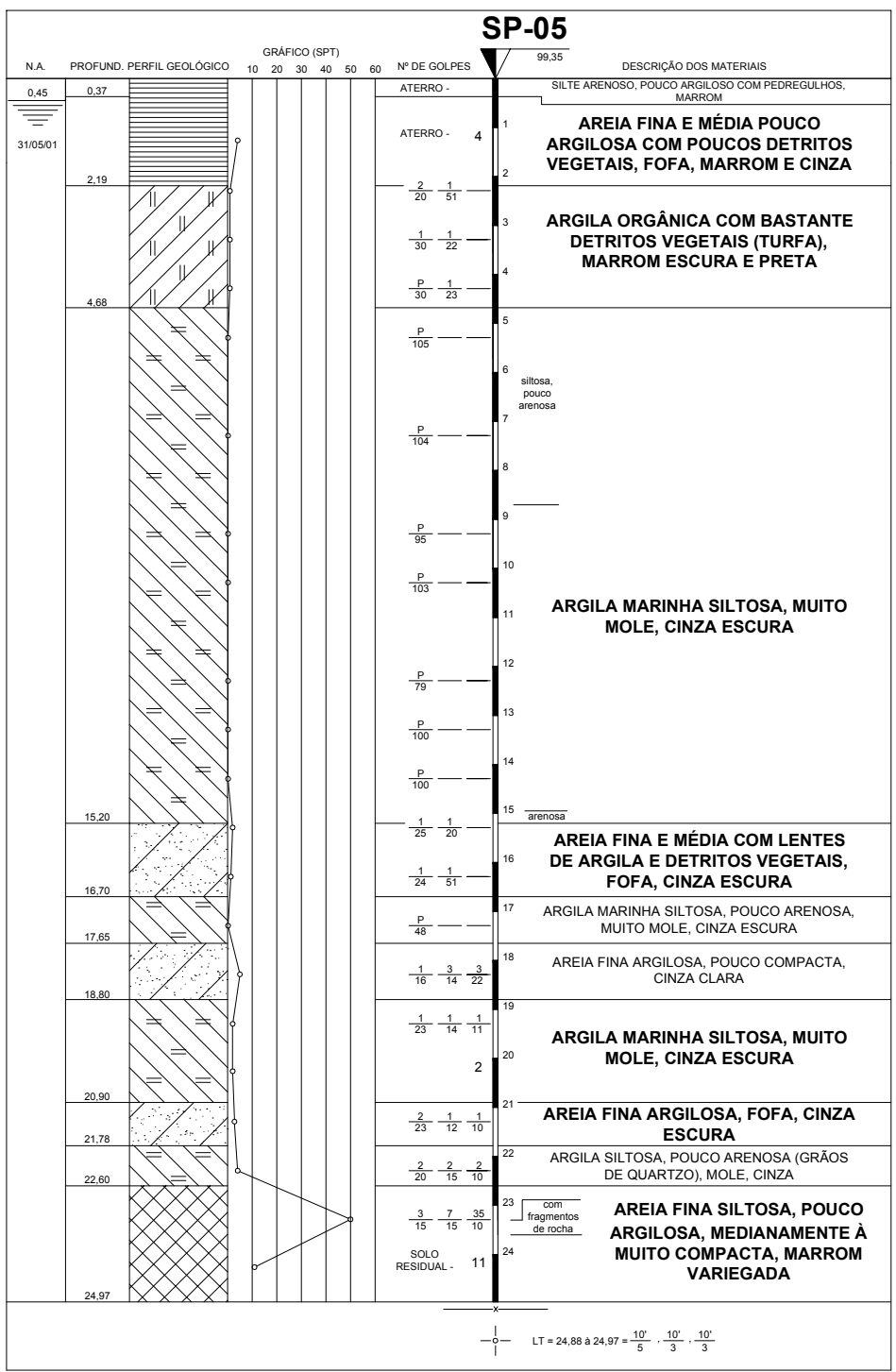

Figura 3.10 - Sondagem SP 05 - Túzzolo Engenharia. 


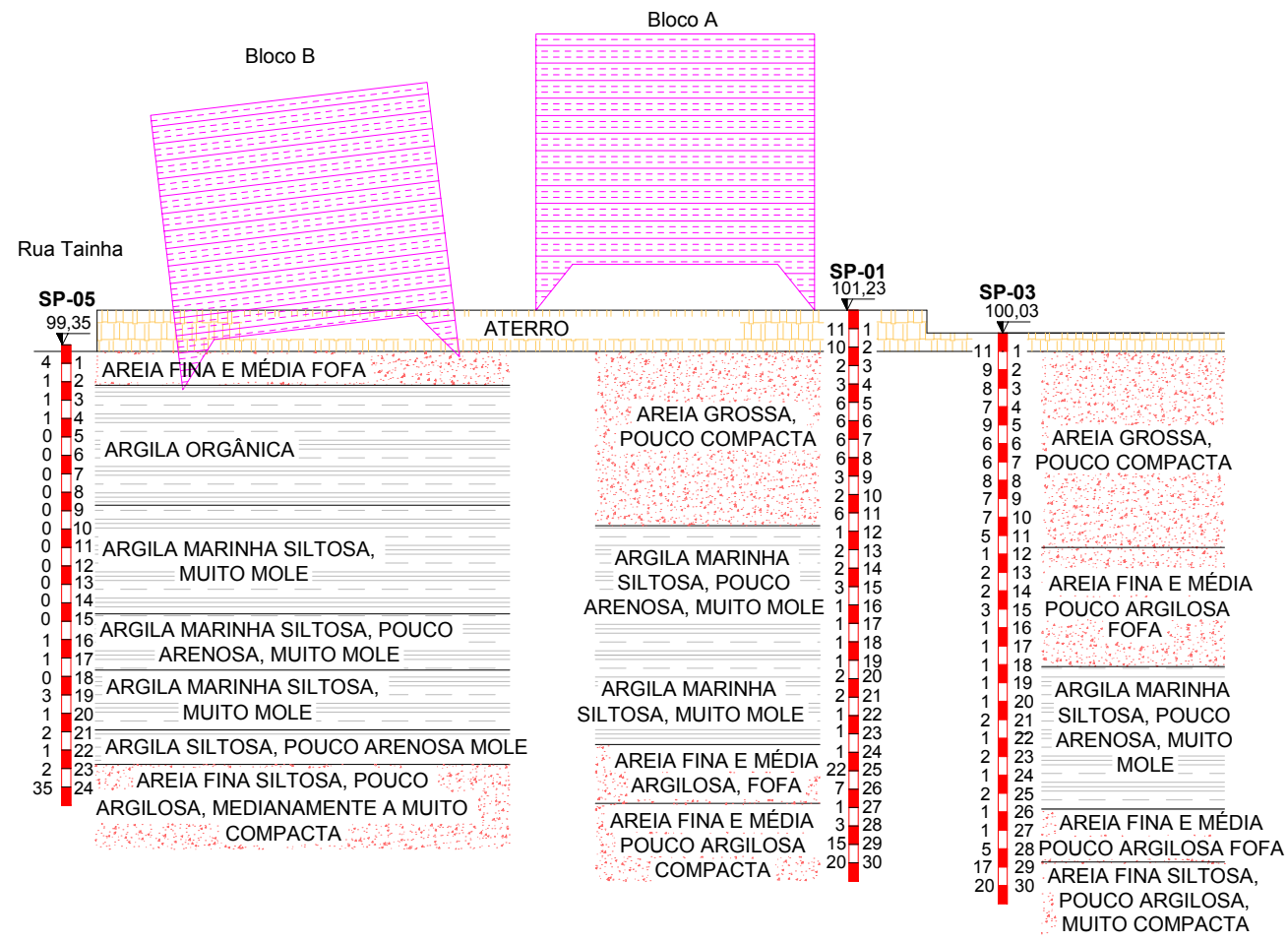

Figura 3.11 - Vista em corte do subsolo.

Os resultados obtidos indicaram que o perfil geológico variou um pouco dentro do terreno. Pode-se dizer que as amostras coletadas próximas à frente do terreno, junto à $A v$ Marginal, indicaram melhores propriedades se comparadas às coletadas no fundo, junto à Rua Tainha. Isso vem confirmar, ainda mais, o motivo pelo qual apenas o bloco "B" do condomínio desabou: sua base de sustentação localizava-se inteiramente sobre o solo de pior qualidade.

Basicamente, os resultados evidenciaram uma primeira camada de solo arenoso, pouco compacto, com espessura variando de $10 \mathrm{~m}$ na frente do terreno a $2 \mathrm{~m}$ no fundo. Abaixo dessas cotas, o material predominante encontrado foi a argila marinha siltosa, muito mole e de cor escura. Aos $25 \mathrm{~m}$ de profundidade, aproximadamente, o material sondado caracterizou-se como areia fina siltosa, pouco argilosa, medianamente a muito compacta, e impenetrável à ferramenta de percussão. 


\subsection{CAUSA DA RUPTURA DAS ESTACAS}

Como se pode inferir dos resultados das sondagens, foram encontradas espessas camadas de solos com mínima capacidade de suporte e extrema compressibilidade. Conceitualmente, sabe-se que solos com essas características dificultam a execução de fundações e atuam em sentido desfavorável para uma boa interação solo-estrutura.

Meses antes de se efetivar o colapso, os condôminos observaram um grande deslocamento, de aproximadamente $30 \mathrm{~cm}$, no piso do estacionamento sob o bloco “B”. Tal ocorrência levou à constatação da exposição da porção superior das vigasbaldrame, causando transtornos na utilização do estacionamento.

Para solucionar o problema o piso foi novamente nivelado, com o acréscimo de mais aterro. A figura 3.12 mostra um corte esquemático do subsolo, verificado sob o bloco "B".

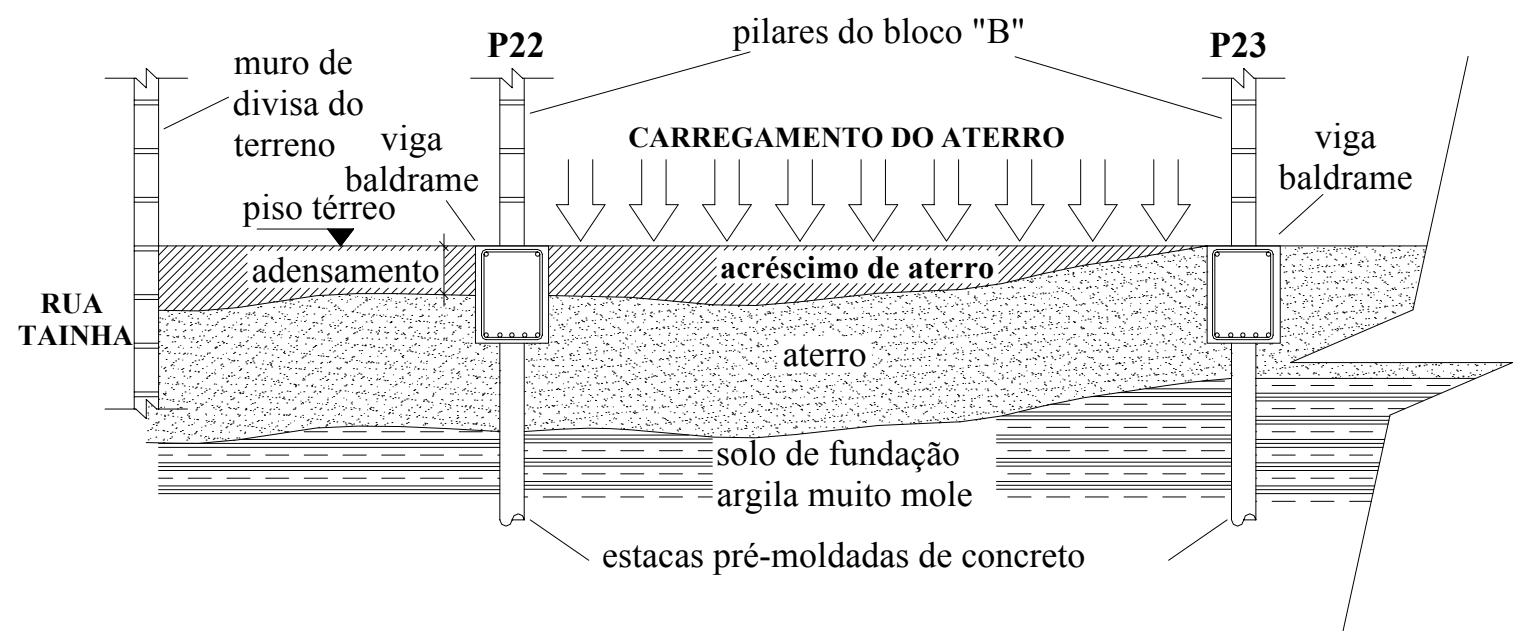

Figura 3.12 - Perfil do solo sob o bloco " $B$ "

Apesar da aparente solução, a medida de caráter imediato contribuiu para agravar a situação, visto que, com o aumento do carregamento, acelerou-se o processo de adensamento que o solo de fundação já vinha sofrendo.

O item 3.2.3 faz menção ao processo de adensamento ocorrido em solos finos. Pode-se dizer que quanto maior for o índice de plasticidade (IP) do solo em questão, maior será sua compressibilidade. Como o perfil geológico do terreno é 
composto por uma grande porcentagem de argila marinha siltosa muito mole, ele possui alto índice de plasticidade. Isso explica o deslocamento excessivo verificado no piso do estacionamento.

Com o aumento do carregamento do solo, também ocorreram grandes tensões horizontais, que também atuaram ao longo dos fustes das estacas. Esse empuxo lateral é conhecido como "Efeito Tschebotarioff". O item 3.2.4 mostra que, quanto maior for a plasticidade do solo submetido a um carregamento, maior será a relação entre as tensões horizontais e verticais, denominada coeficiente de empuxo em repouso $\left(K_{0}\right)$. Isso significa que, no caso do terreno investigado, grande parcela da tensão vertical originada pelo aterro também atuou no sentido horizontal, o que contribuiu para fletir as estacas de fundação. A figura 3.13 esquematiza o empuxo horizontal devido ao efeito da sobrecarga vertical unilateral - "Efeito Tschebotarioff".

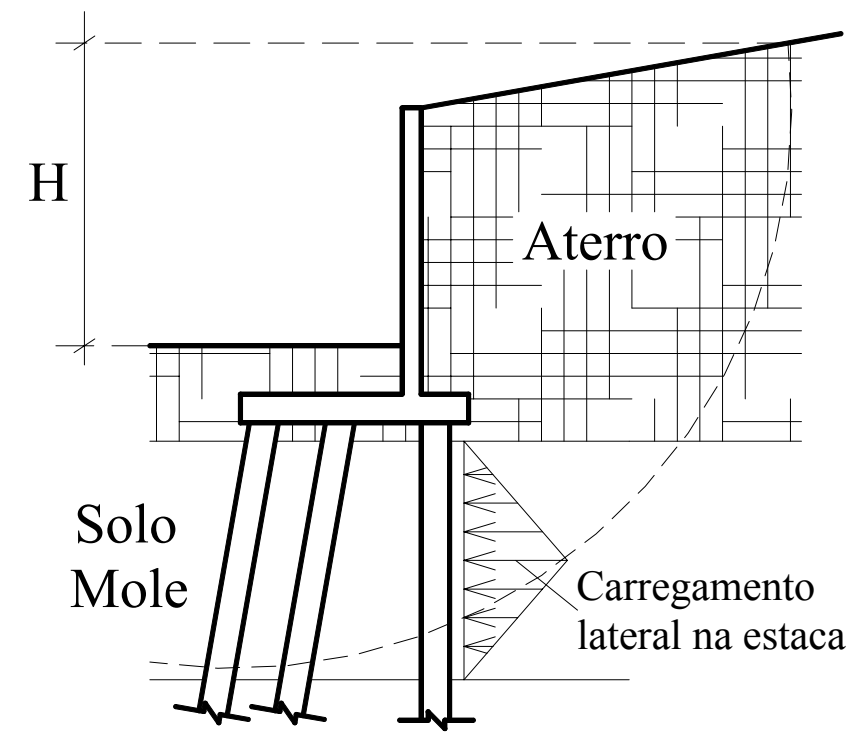

Figura 3.13 - Empuxo lateral devido ao adensamento do solo mole - Ratton (1983).

A pouca rigidez da estrutura de transição, localizada no pavimento térreo, também contribuiu para a efetivação do colapso. O sistema foi incapaz de redistribuir os esforços provenientes da ruptura das estacas e atuou como um mecanismo, depois do ocorrido. Devido a isso, não se evitou que todo o edifício cedesse e danificasse completamente o pavimento térreo. 
A figura 3.14 mostra a baixa inércia da maioria dos pilares do térreo, na direção em que houve o deslocamento horizontal do edifício. Pode-se verificar que, com a ruptura das estacas, muitos dos pilares localizados no térreo tombaram e outros penetraram no interior do pavimento superior.

Ficou evidente que o solo de fundação foi o principal responsável pela ocorrência do sinistro. Por ser muito mole, não proporcionou resistência lateral às fundações nem restringiu seus deslocamentos horizontais, permitindo que elas perdessem a estabilidade e rompessem por flexo-compressão.

O empuxo lateral no solo de fundação, devido ao peso excessivo do aterro, solicitou lateralmente os elementos de fundação. Estes, por sua vez, não foram dimensionados para suportar tal esforço. O resultado foi a ruptura de todas as estacas próximas ao fundo do terreno, região em que houve maior adensamento e, por conseguinte, maior carregamento horizontal. A figura 3.15 ilustra o mecanismo ora mencionado.

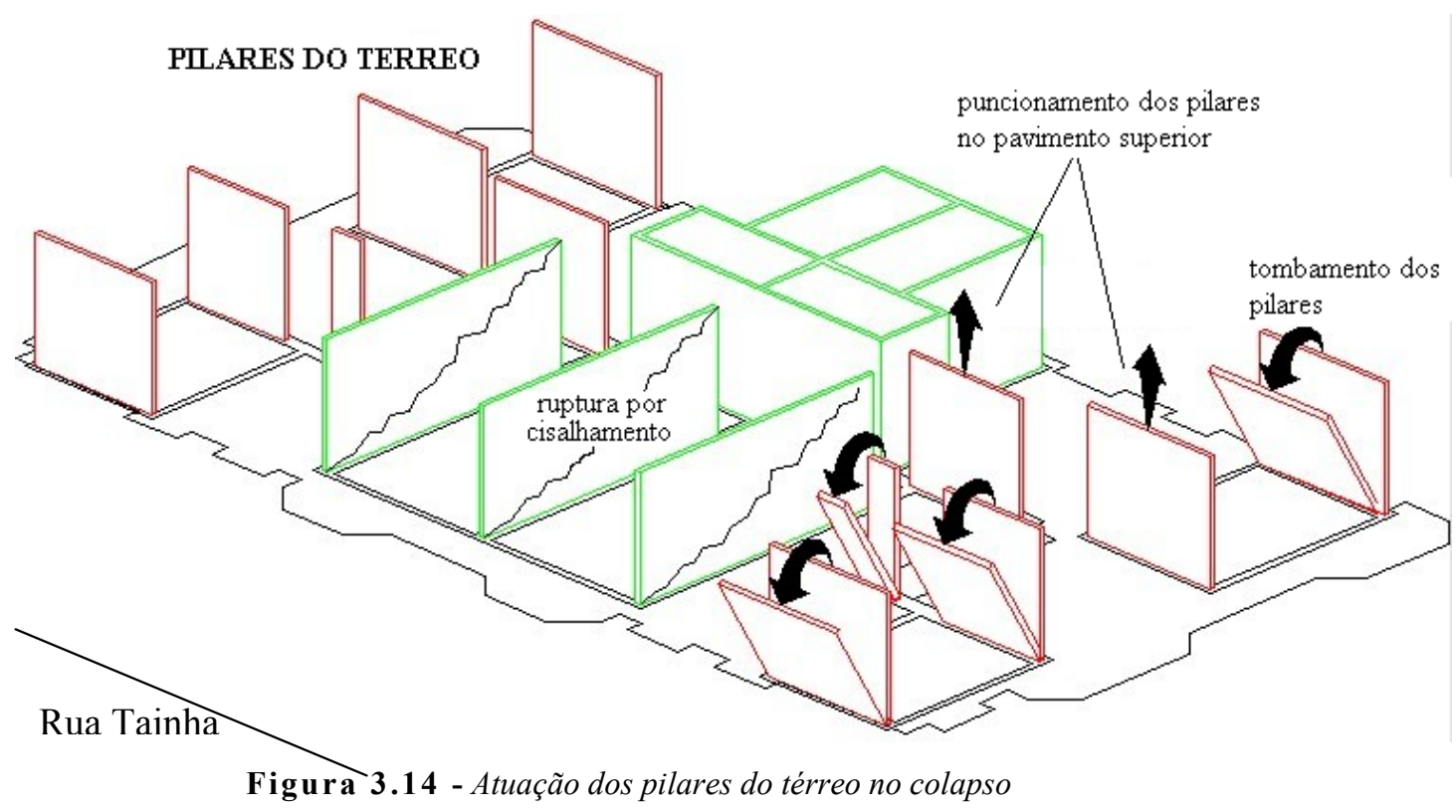




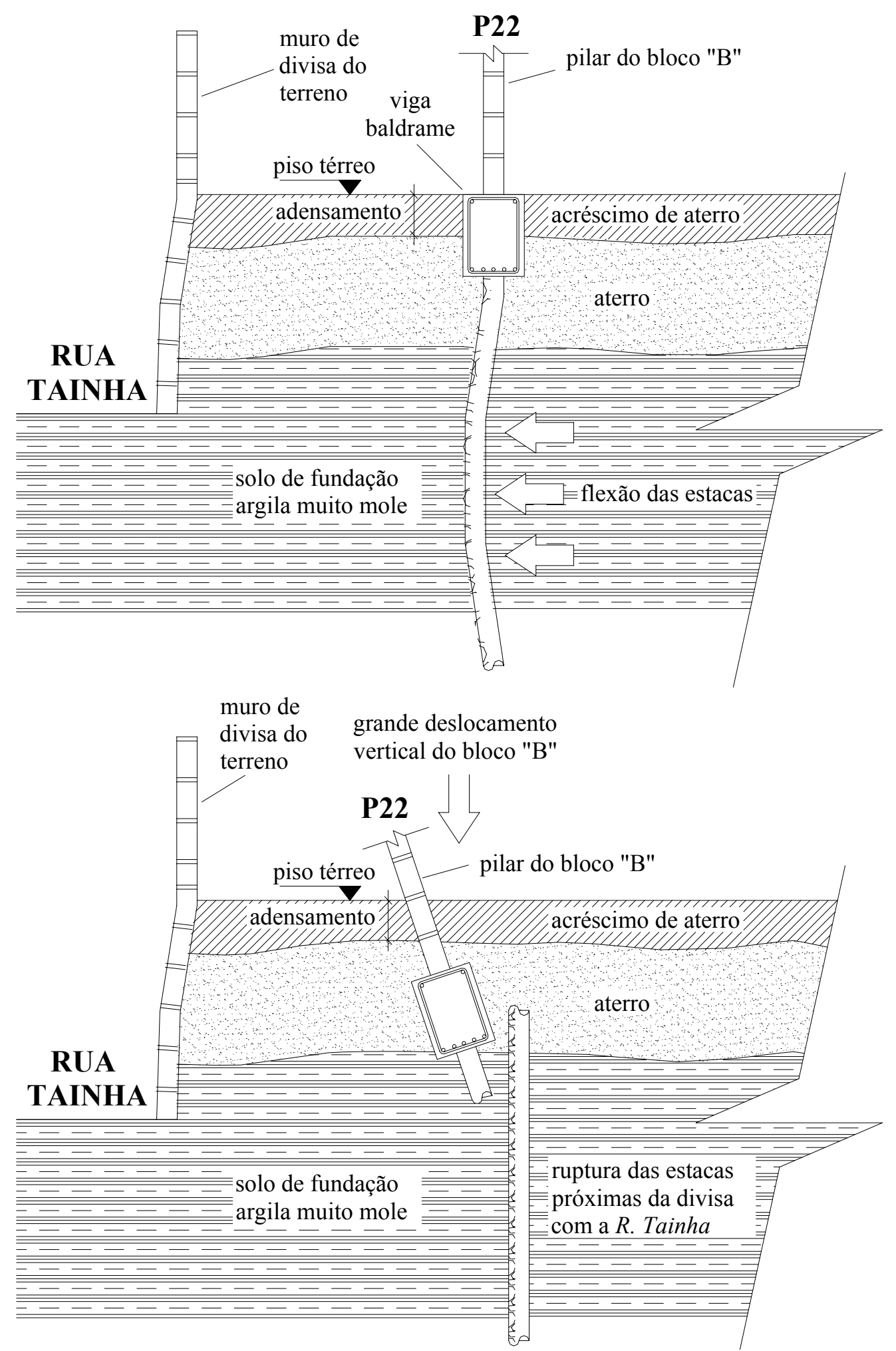

Figura 3.15 - Ruptura das estacas próximas à Rua Tainha 


\subsection{AÇÕES NAS ESTACAS DEVIDAS À SUPERESTRUTURA}

Para quantificar as forças atuantes nas fundações do edifício, elaborou-se um modelo numérico capaz de representar fisicamente o comportamento da estrutura. O programa STRAP 9.0 foi utilizado como ferramenta de cálculo na obtenção dos resultados.

\subsubsection{MODELAGEM}

Pode-se observar na figura 3.16 que, para modelar a estrutura do edifício, algumas considerações foram adotadas:

- Tendo em conta os objetivos deste trabalho, considerou-se adequado modelar apenas do nível da primeira laje para baixo e, desta forma, todo carregamento proveniente do peso do edifício foi admitido aplicado nas vigas de transição;

- Por se tratar de um edifício com um eixo de simetria, o cálculo restringiu-se à metade da estrutura;

- Para simular a continuidade, foram impedidos os deslocamentos dos nós situados no eixo de simetria, nas orientações X1, X5 e X6;

- Os elementos como pilares e paredes situados no eixo de simetria foram considerados com a metade da largura;

- Os resultados foram obtidos admitindo-se linearidades física e geométrica;

- $\quad$ A laje de transição foi simulada como sendo um diafragma rígido;

- As vigas foram simuladas por elementos finitos lineares;

- $\quad$ Adotou-se a inércia dos elementos lineares como sendo a da seção bruta;

- Os pilares de alvenaria estrutural foram analisados como elementos finitos retangulares de chapa; 
- Nos pontos onde havia estacas, foram adotados apoios elásticos nas direções $\mathrm{X} 1, \mathrm{X} 2, \mathrm{X} 3$, e as rotações não foram impedidas. A tabela 3.5 apresenta os valores das constantes elásticas.
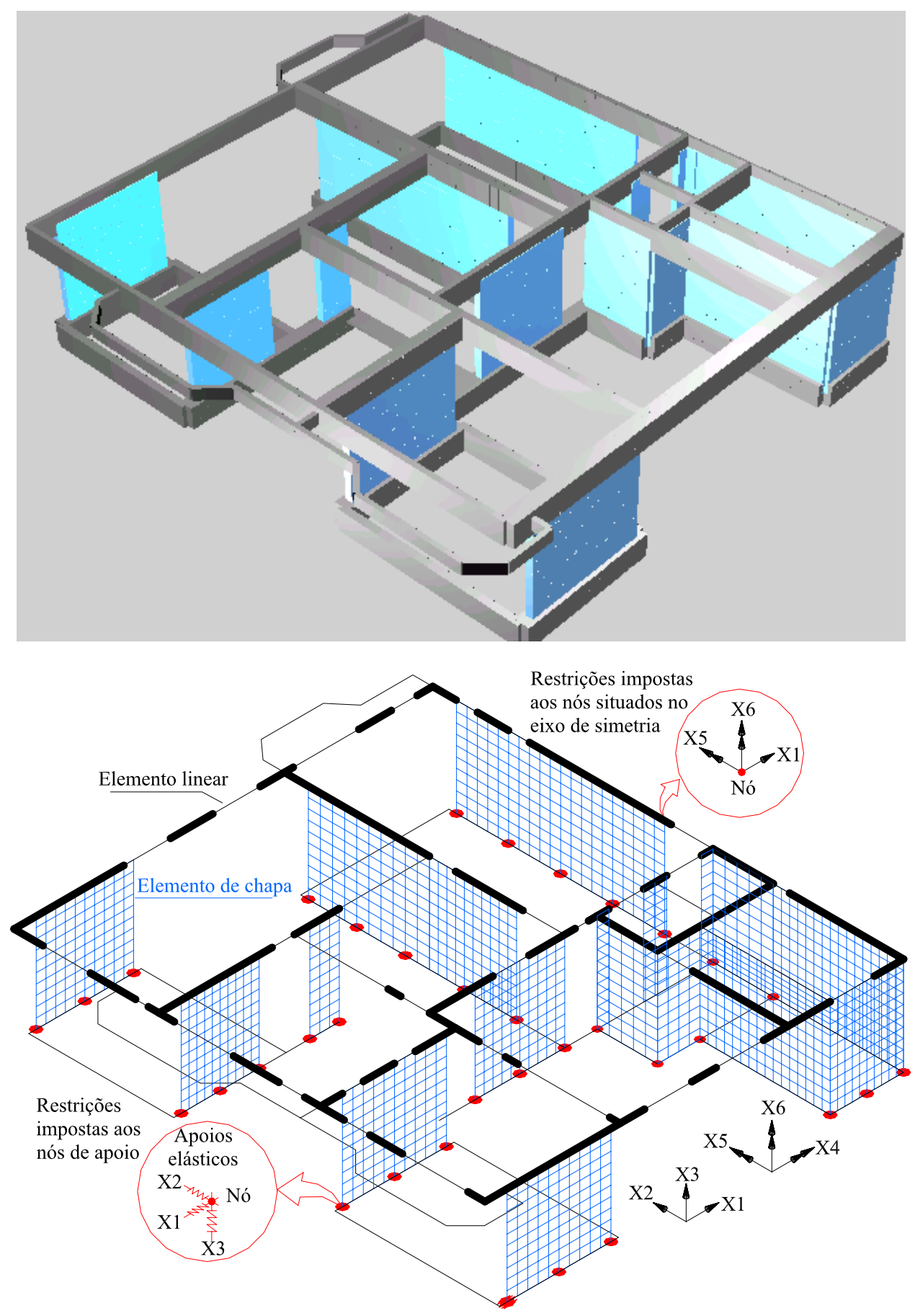

Figura 3.16 - Arquitetura do modelo criado para determinar as reações nas estacas. 
Os valores das características físicas utilizadas na modelagem estão apresentados na tabela 3.4 e a figura 3.17 mostra os elementos do modelo associados com seus respectivos números de propriedades.

Tabela 3.4 Propriedades físicas dos materiais utilizados na estrutura do modelo.

\begin{tabular}{ccccc}
\hline \multicolumn{5}{c}{ Tabela de Materiais } \\
\hline No & Nome & $\begin{array}{c}\text { Módulo de } \\
\text { Elasticidade }-\mathbf{E} \\
\left(\mathbf{k N} / \mathbf{m}^{\mathbf{2}}\right)\end{array}$ & $\begin{array}{c}\text { Coeficiente de } \\
\text { Poisson }-v\end{array}$ & $\begin{array}{c}\text { Módulo } \\
\text { Transversal - G } \\
\left(\mathbf{k N} / \mathbf{m}^{\mathbf{2}}\right)\end{array}$ \\
\hline 1 & C_20 & $0,288 \cdot 10^{8}$ & 0,2 & $0,120.10^{8}$ \\
2 & Bloc & $0,336 \cdot 10^{7}$ & 0,2 & $0,140.10^{7}$ \\
\hline
\end{tabular}

\begin{tabular}{|c|c|}
\hline \multicolumn{2}{|c|}{ Propriedade № 1 (unid. cm) } \\
\hline \multirow{3}{*}{$\mathrm{X} 3$} & $\mathrm{~A}=0,12 \cdot 10^{4}$ \\
\hline & $\mathrm{I}_{2}=0,36 \cdot 10^{6}$ \\
\hline & $\mathrm{I}_{3}=0,40 \cdot 10^{5}$ \\
\hline & $\mathrm{J}=0,1264.10^{6}$ \\
\hline & $\mathrm{X} 2 \mathrm{Mat}=1-\mathrm{C} \_20$ \\
\hline & Perímetro $=160$ \\
\hline & $\mathrm{H}_{2}=20$ \\
\hline & $\mathrm{H}_{3}=60$ \\
\hline
\end{tabular}

Propriedade № 3 (unid. cm)

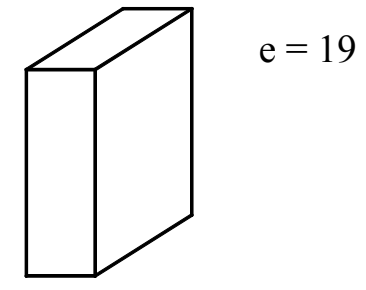

Mat $=2-$ Bloc

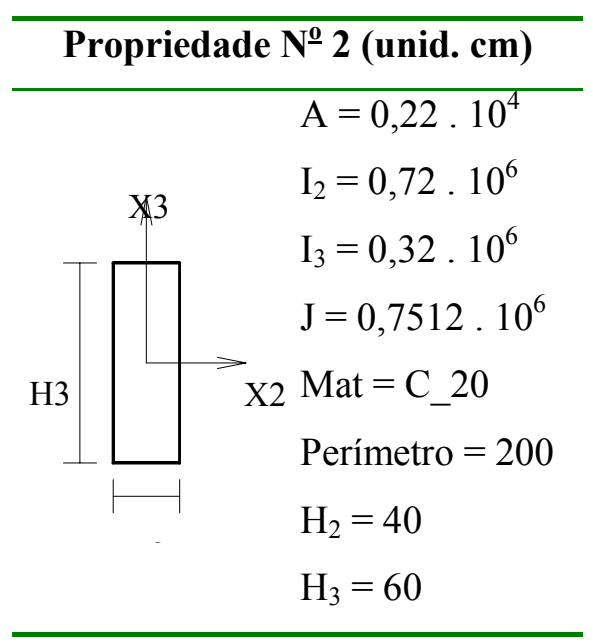

Propriedade No $\mathbf{4}$ (unid. cm)
$\mathrm{A}=0,36 \cdot 10^{3}$
$\mathrm{I}_{2}=0,27 \cdot 10^{5}$
$\mathrm{I}_{3}=0,432 \cdot 10^{4}$
$\mathrm{~J}=0,1293.10^{5}$
$\mathrm{X} 32 \mathrm{Mat}=1-\mathrm{C}_{2} 20$
$\mathrm{Herímetro}=84$
$\mathrm{H}_{2}=12$
$\mathrm{H}_{3}=30$




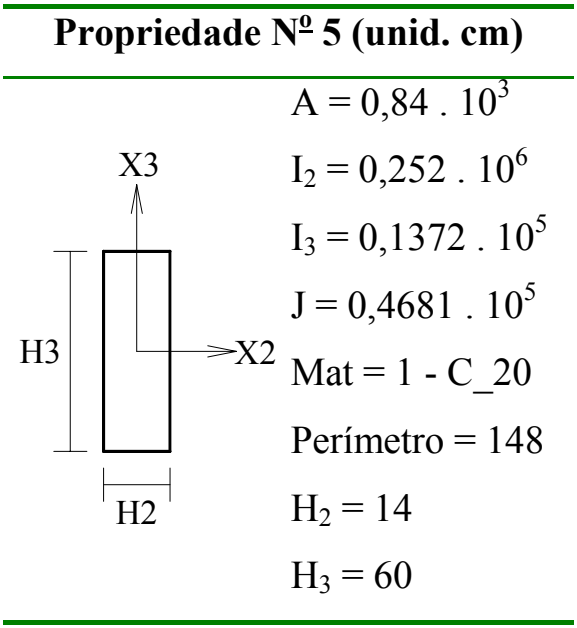

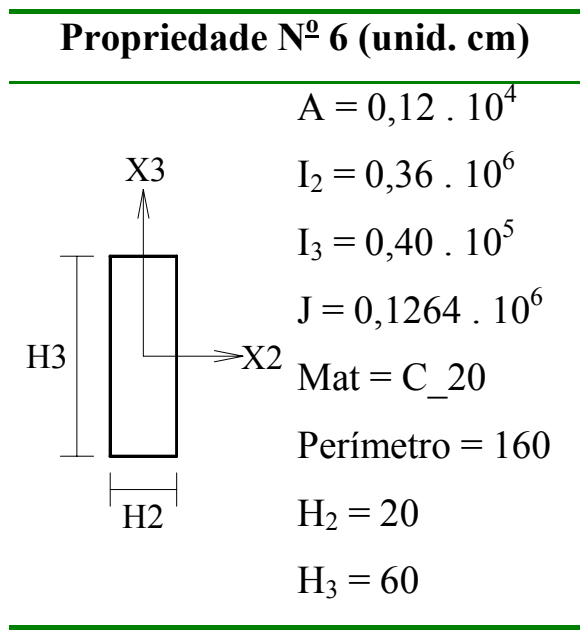

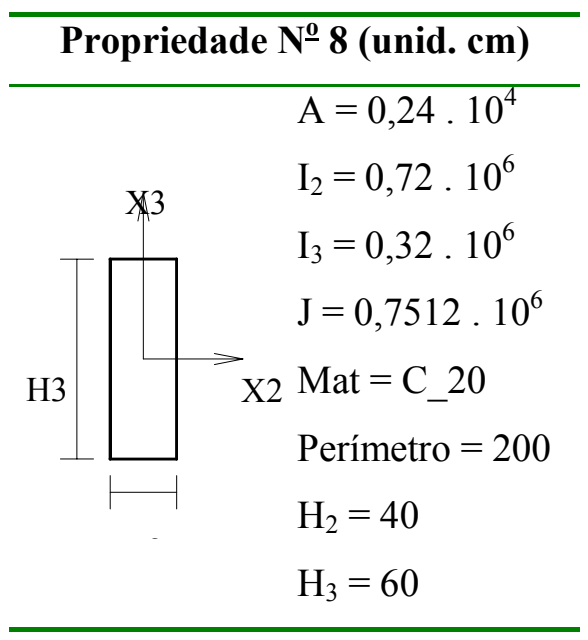

\section{Propriedade № 10 (unid. cm)}

$\mathrm{A}=0,12 \cdot 10^{4}$

$\mathrm{I}_{2}=0,36 \cdot 10^{6}$

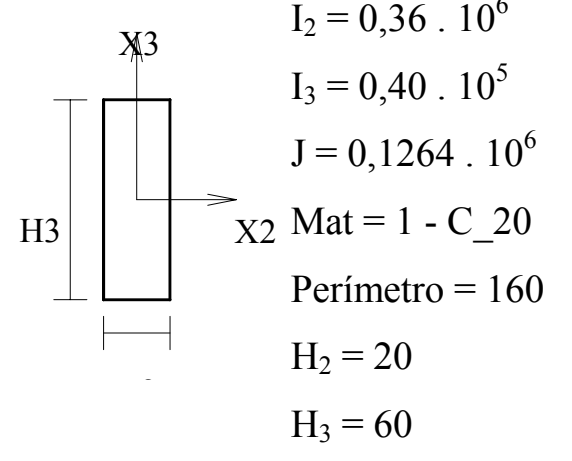




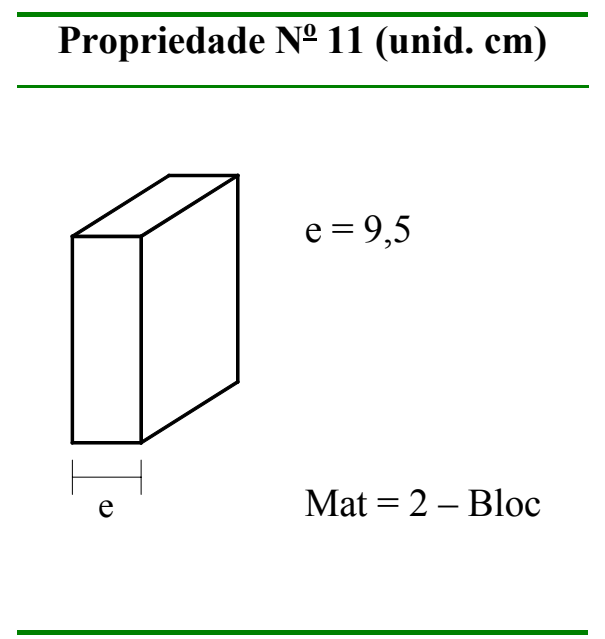

\begin{tabular}{|c|c|c|}
\hline \multicolumn{3}{|c|}{ Propriedade № 12 (unid. cm) } \\
\hline \multirow{3}{*}{\multicolumn{2}{|c|}{$\mathrm{X} 3$}} & $\mathrm{~A}=0,42 \cdot 10^{3}$ \\
\hline & & $I_{2}=0,126 \cdot 10^{6}$ \\
\hline & & $I_{3}=0,1715 \cdot 10^{4}$ \\
\hline \multirow{5}{*}{$\mathrm{H} 3$} & & $\mathrm{~J}=0,6356.10^{4}$ \\
\hline & & $\mathrm{X} 2 \mathrm{Mat}=1-\mathrm{C} \_20$ \\
\hline & & Perímetro $=134$ \\
\hline & $\mathrm{H} 2$ & $\mathrm{H}_{2}=7$ \\
\hline & & $\mathrm{H}_{3}=60$ \\
\hline
\end{tabular}

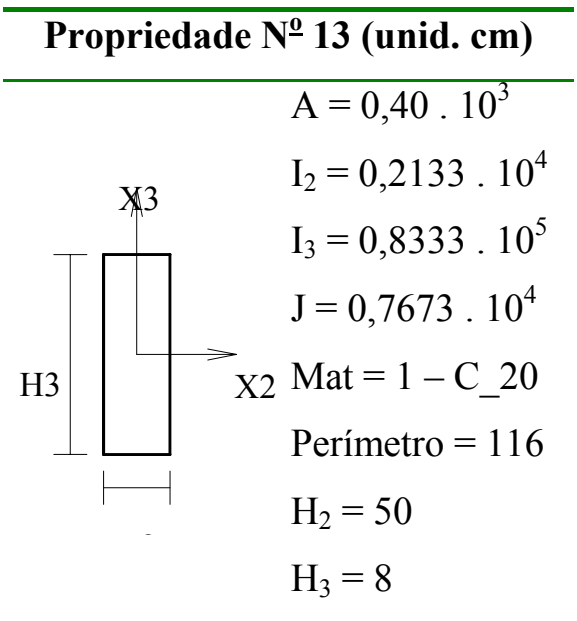

Tabela 3.5 Constante elástica dos apoios.

Constante elástica dos apoios $(\mathrm{kN} / \mathrm{m})$

\begin{tabular}{ccccccc}
\hline & $\mathbf{X 1}$ & $\mathbf{X 2}$ & $\mathbf{X 3}$ & $\mathbf{X 4}$ & $\mathbf{X 5}$ & $\mathbf{X 6}$ \\
Fora do eixo de simetria & 3000 & 3000 & 30000 & 0 & 0 & 0 \\
No eixo de simetria & 1500 & 1500 & 15000 & 0 & 0 & 0 \\
\hline
\end{tabular}

- Determinação da constante elástica:

$$
\left\{\begin{array}{c}
\text { carregamento usual } \Rightarrow 300 \mathrm{kN} \\
\text { recalque admissível } \Rightarrow 1 \quad \mathrm{~cm}
\end{array}\right\} \Rightarrow 30000 \frac{\mathrm{kN}}{\mathrm{m}}
$$




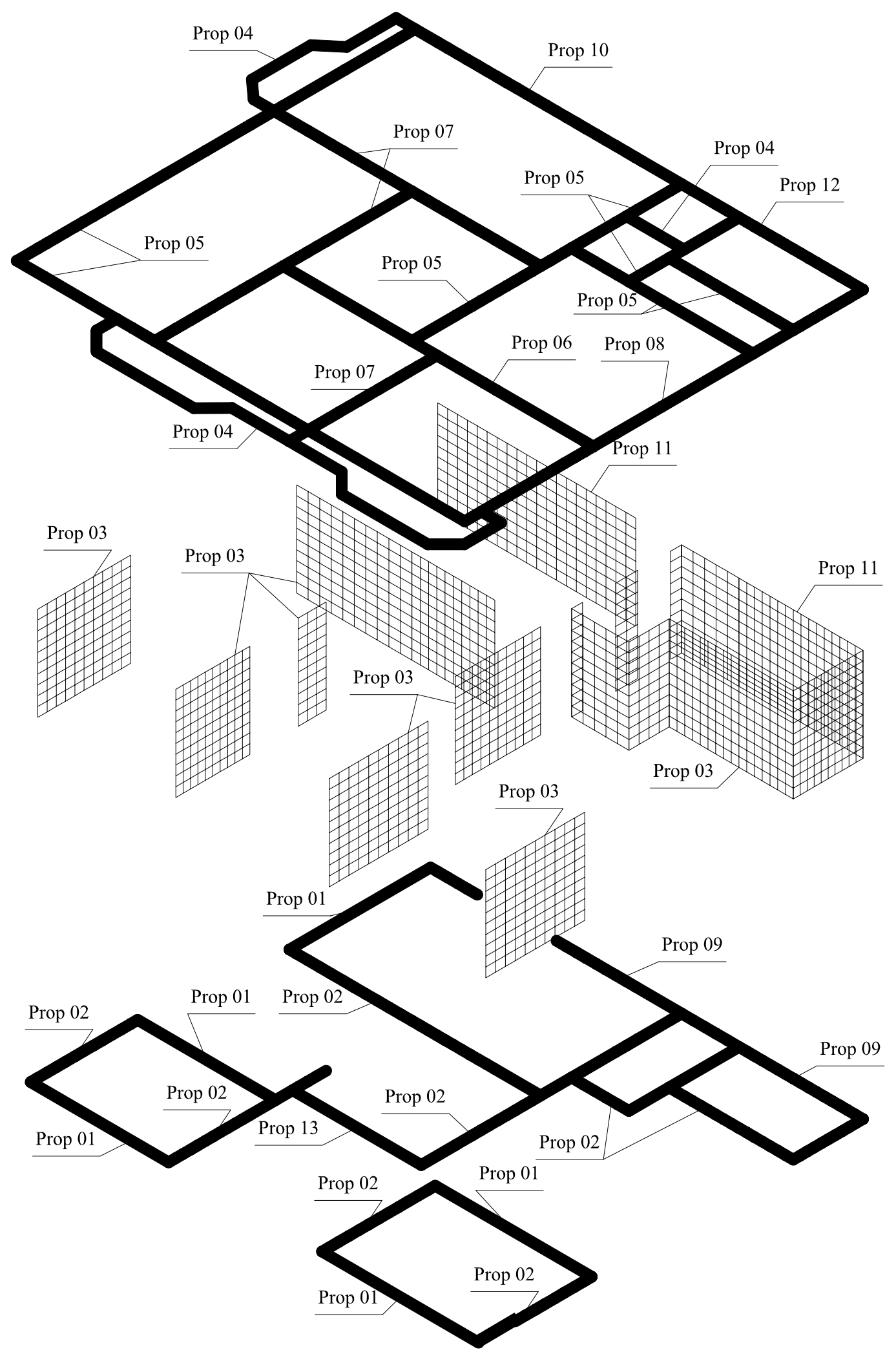

Figura 3.17 - Propriedades dos elementos do modelo. 


\subsubsection{CARREGAMENTO NAS VIGAS DE TRANSIÇÃO}

Os carregamentos das lajes foram distribuídos nas vigas por meio de áreas de influência. Essas áreas, para as vigas de apoio das vigotas, são bem maiores do que para as das vigas do contorno, por se tratarem de lajes pré-moldadas apoiadas em uma só direção. A figura 3.18 mostra que o ângulo de $22,5^{\circ}$, adotado para delimitar as áreas de influência, transferiu maior parcela dos carregamentos aos apoios das vigotas. A tabela 3.6 indica as dimensões das lajes, sua área total e as áreas de influência.

As paredes internas, que não possuem função estrutural, foram adotadas como sendo elementos de carregamento superficial. Assim, todo peso proveniente dessas paredes foi distribuído pela superfície da laje de apoio.

Para determinar o carregamento total na estrutura de transição, as paredes estruturais foram divididas em 25 grupos (figura 3.19). Esses grupos são formados por parte das paredes estruturais que não possuem aberturas, em toda a elevação do edifício, tais como: janelas, portas e vãos livres. Os grupos, por serem porções desprovidas de aberturas, são responsáveis pela transmissão dos esforços de todo o edifício às vigas de transição. Os outros trechos da alvenaria, que possuem aberturas, necessitam encaminhar seus carregamentos aos grupos adjacentes. A figura 3.20 ilustra a transmissão dos esforços ao longo do edifício.

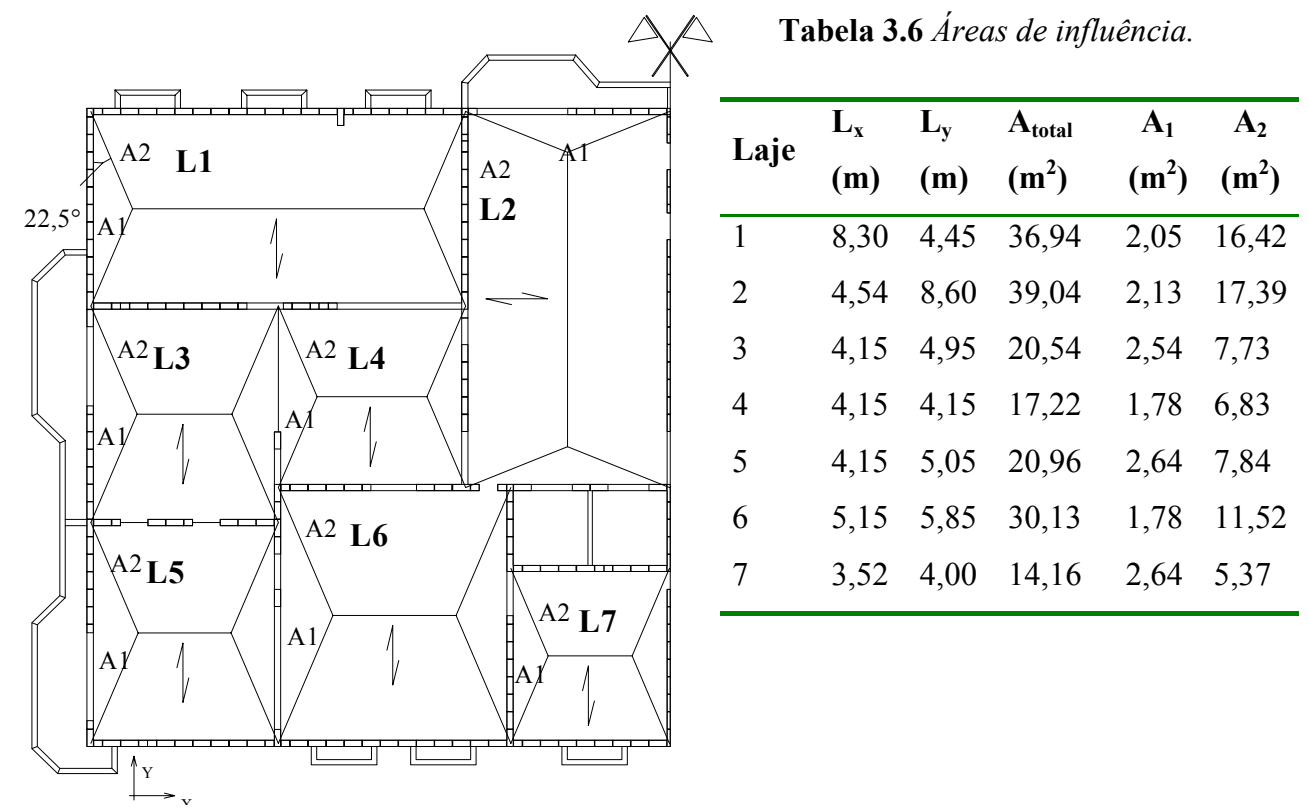

Figura 3.18 - Áreas de influência das lajes. 


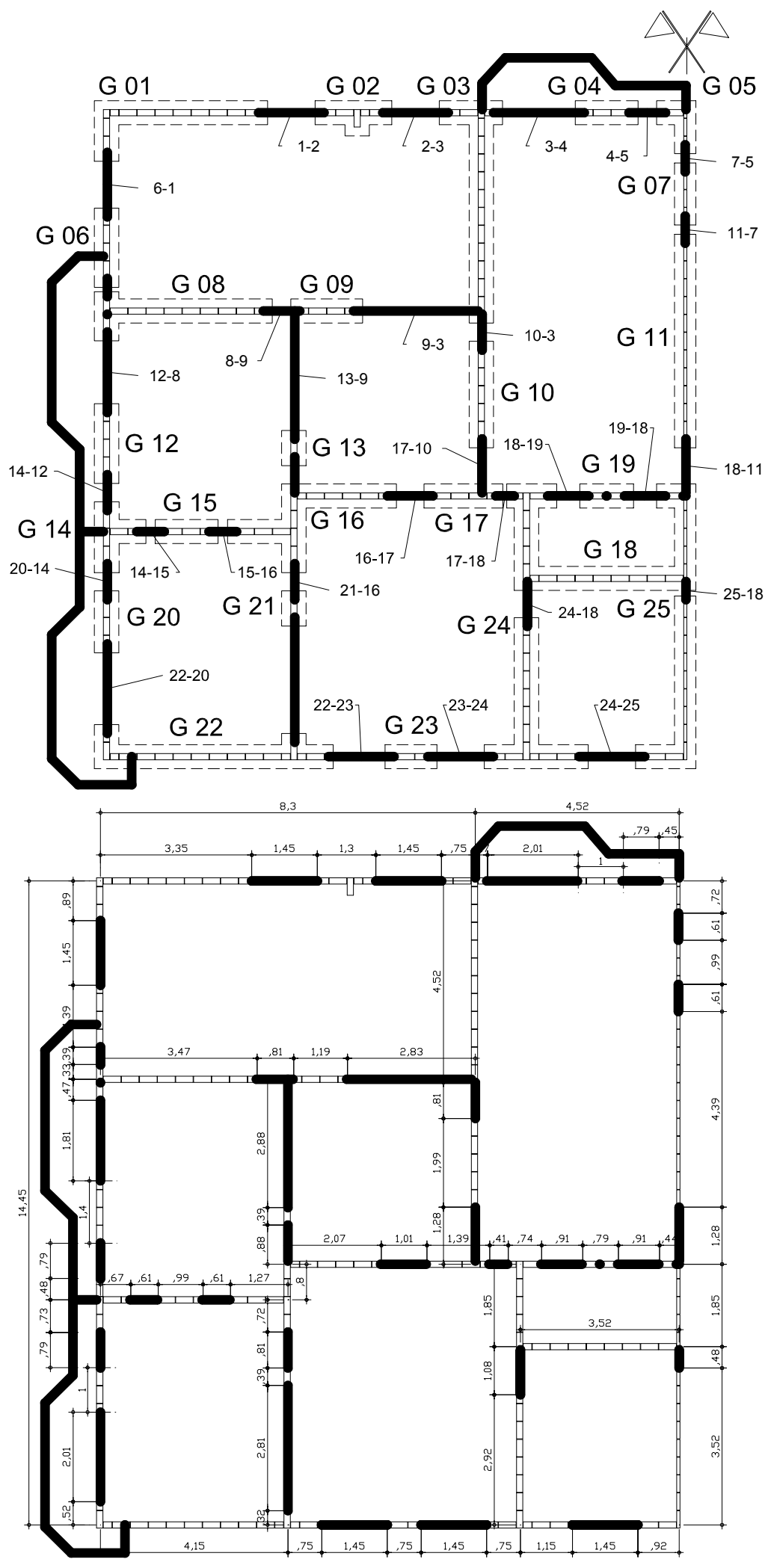

Figura 3.19 - Divisão das paredes estruturais em grupos. 


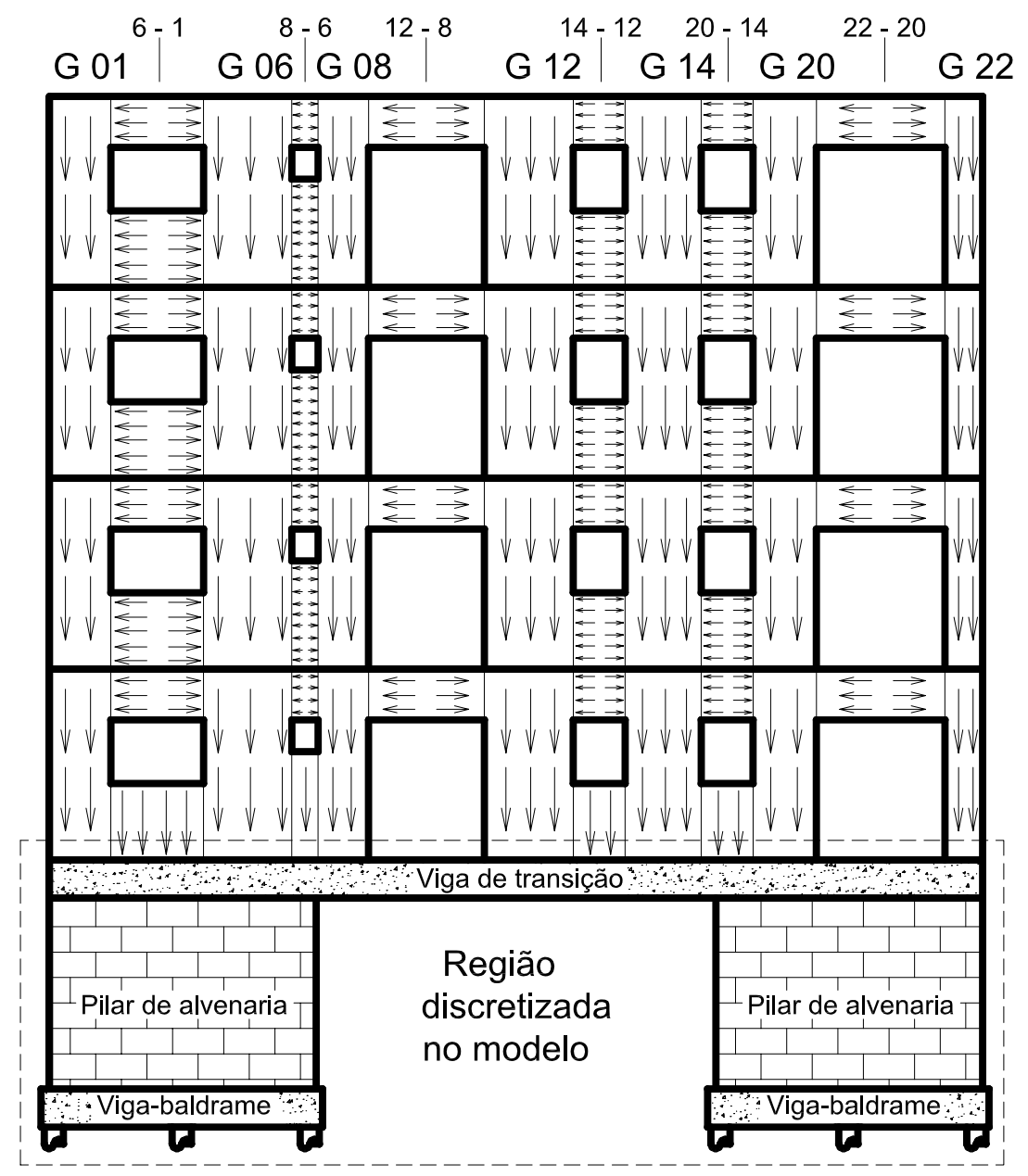

Figura 3.20 - Transmissão do carregamento ao longo do edifício.

As tabelas 3.7 e 3.8 mostram, respectivamente, os valores dos carregamentos lineares e superficiais atuantes nos pavimentos-tipo. A tabela 3.9 apresenta a porcentagem do peso que atua em cada elemento de apoio e de contorno das lajes; já as figuras 3.21 e 3.22 representam a reação de apoio das lajes e o carregamento total atuante nas vigas de transição, respectivamente. 
Tabela 3.7 Carregamentos lineares.

\begin{tabular}{ccccc}
\hline Elemento & $\boldsymbol{\gamma}\left(\mathbf{k N} / \mathbf{m}^{3}\right)$ & Base (cm) & Altura $(\mathbf{c m})$ & Peso $(\mathbf{k N} / \mathbf{m})$ \\
\hline V (14/60) & 25,0 & 14 & 60 & 2,1 \\
V (14/52) & 25,0 & 14 & 52 & 1,8 \\
V (14/40) & 25,0 & 14 & 40 & 1,4 \\
V (20/60) & 25,0 & 20 & 60 & 3,0 \\
V (30/60) & 25,0 & 30 & 60 & 4,5 \\
V (40/60) & 25,0 & 40 & 60 & 6,0 \\
Par int. & 14,0 & 15 & 280 & 5,9 \\
Par ext. & 14,0 & 20 & 280 & 7,8 \\
Janela & 14,0 & 20 & 180 & 5,0 \\
Porta & 14,0 & 20 & 60 & 1,7 \\
Parapeito & 14,0 & 20 & 100 & 2,8 \\
1/2 par ext. & 14,0 & 10 & 280 & 3,9 \\
1/2 V (14/40) & 25,0 & 7 & 40 & 0,7 \\
$1 / 2$ V (30/60) & 25,0 & 15 & 60 & 2,3 \\
\hline
\end{tabular}

Tabela 3.8 Carregamentos superficiais.

\begin{tabular}{|c|c|c|c|c|c|c|c|c|c|c|}
\hline \multirow[b]{2}{*}{ Laje } & \multicolumn{3}{|c|}{$\begin{array}{c}\text { Carregamento peso } \\
\text { laje }\end{array}$} & \multicolumn{3}{|c|}{$\begin{array}{c}\text { Carregamento peso } \\
\text { revestimento }\end{array}$} & \multicolumn{3}{|c|}{$\begin{array}{c}\text { Carregamento peso } \\
\text { paredes internas }\end{array}$} & \multirow{2}{*}{$\begin{array}{c}\text { Carreg. } \\
\text { Total } \\
\left(\mathrm{kN} / \mathrm{m}^{2}\right)\end{array}$} \\
\hline & $\begin{array}{l}\text { Esp. } \\
(\mathrm{cm})\end{array}$ & $\begin{array}{c}\gamma \\
\left(\mathrm{kN} / \mathrm{m}^{3}\right)\end{array}$ & $\begin{array}{c}\text { Peso } \\
\left(\mathrm{kN} / \mathrm{m}^{2}\right)\end{array}$ & $\begin{array}{l}\text { Esp. } \\
\text { (cm) }\end{array}$ & $\begin{array}{c}\gamma \\
\left(\mathrm{kN} / \mathrm{m}^{3}\right)\end{array}$ & $\begin{array}{c}\text { Peso } \\
\left(\mathbf{k N} / \mathbf{m}^{2}\right)\end{array}$ & $\begin{array}{c}\text { Comp. } \\
\text { Par. } \\
\text { int. (m) }\end{array}$ & $\begin{array}{l}\text { Peso } \\
\text { total } \\
(\mathrm{kN})\end{array}$ & $\begin{array}{c}\text { Carreg. } \\
\text { Superfície } \\
\left(\mathbf{k N} / \mathbf{m}^{2}\right)\end{array}$ & \\
\hline 1 & 12 & 24 & 2,88 & 5 & 19 & 0,95 & 14,5 & 85,3 & 2,31 & 6,14 \\
\hline 2 & 12 & 24 & 2,88 & 5 & 19 & 0,95 & 5,5 & 32,3 & 0,83 & 4,66 \\
\hline 3 & 12 & 24 & 2,88 & 5 & 19 & 0,95 & 2,4 & 14,1 & 0,69 & 4,52 \\
\hline 4 & 12 & 24 & 2,88 & 5 & 19 & 0,95 & 8,5 & 50,0 & 2,90 & 6,73 \\
\hline 5 & 12 & 24 & 2,88 & 5 & 19 & 0,95 & 2,4 & 14,1 & 0,67 & 4,50 \\
\hline 6 & 12 & 24 & 2,88 & 5 & 19 & 0,95 & 8,5 & 50,0 & 1,66 & 5,49 \\
\hline 7 & 12 & 24 & 2,88 & 5 & 19 & 0,95 & 3,3 & 19,4 & 1,37 & 5,20 \\
\hline
\end{tabular}

Tabela 3.9 Carregamentos nas vigas de apoio e contorno.

\begin{tabular}{|c|c|c|c|c|c|}
\hline Laje & $\begin{array}{c}\text { Apoio } \\
(\%)\end{array}$ & $\begin{array}{c}\text { Contorno } \\
(\%)\end{array}$ & $\begin{array}{c}\text { Carregamento } \\
\text { Total } \\
(\mathbf{k N})\end{array}$ & $\begin{array}{c}\text { Carregamento } \\
\text { Viga apoio } \\
(\mathbf{k N} / \mathbf{m})\end{array}$ & $\begin{array}{c}\text { Carregamento } \\
\text { Viga contorno } \\
(\mathrm{kN} / \mathrm{m})\end{array}$ \\
\hline 1 & 89 & 11 & 226,7 & 12,14 & 2,83 \\
\hline 2 & 89 & 11 & 181,9 & 9,42 & 2,19 \\
\hline 3 & 75 & 25 & 92,8 & 8,42 & 2,32 \\
\hline 4 & 79 & 21 & 115,9 & 11,08 & 2,89 \\
\hline 5 & 75 & 25 & 94,4 & 8,51 & 2,35 \\
\hline 6 & 76 & 24 & 165,4 & 12,28 & 3,33 \\
\hline 7 & 77 & 23 & 73,6 & 7,97 & 2,15 \\
\hline
\end{tabular}



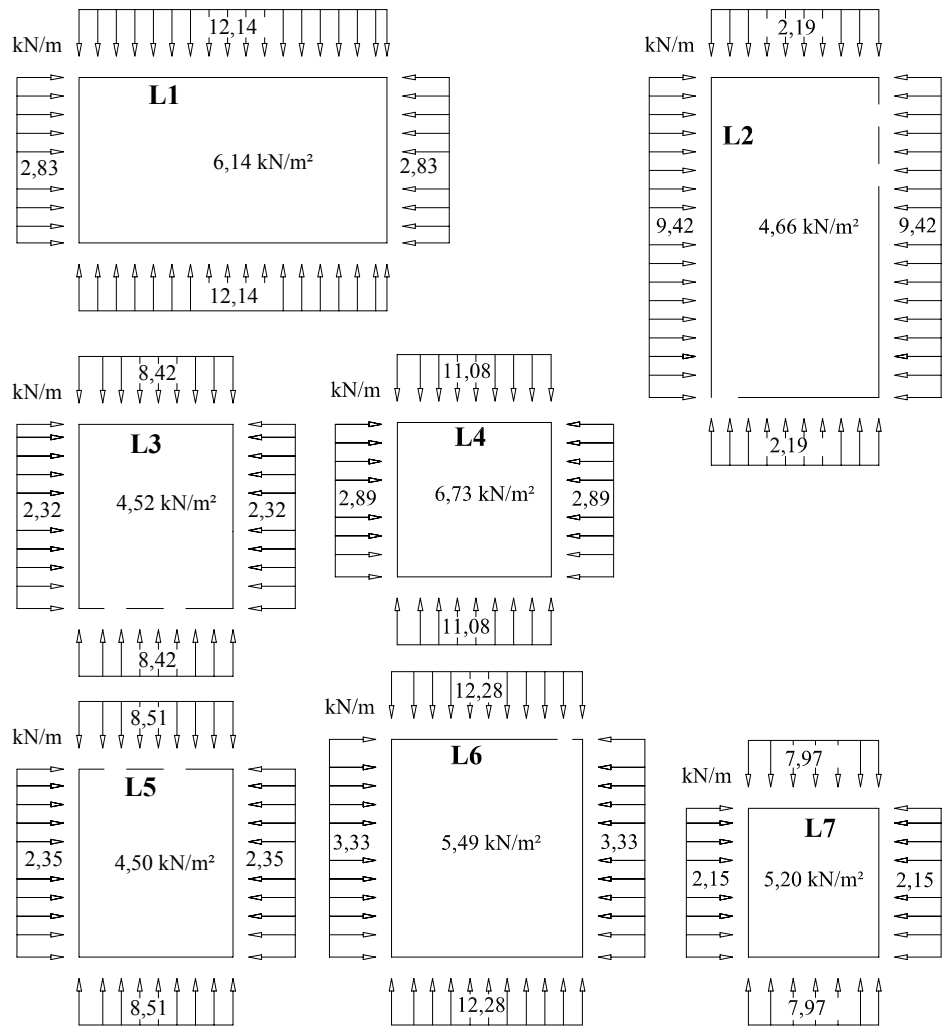

Figura 3.21 - Reações de apoio das lajes $(\mathrm{kN} / \mathrm{m})$.

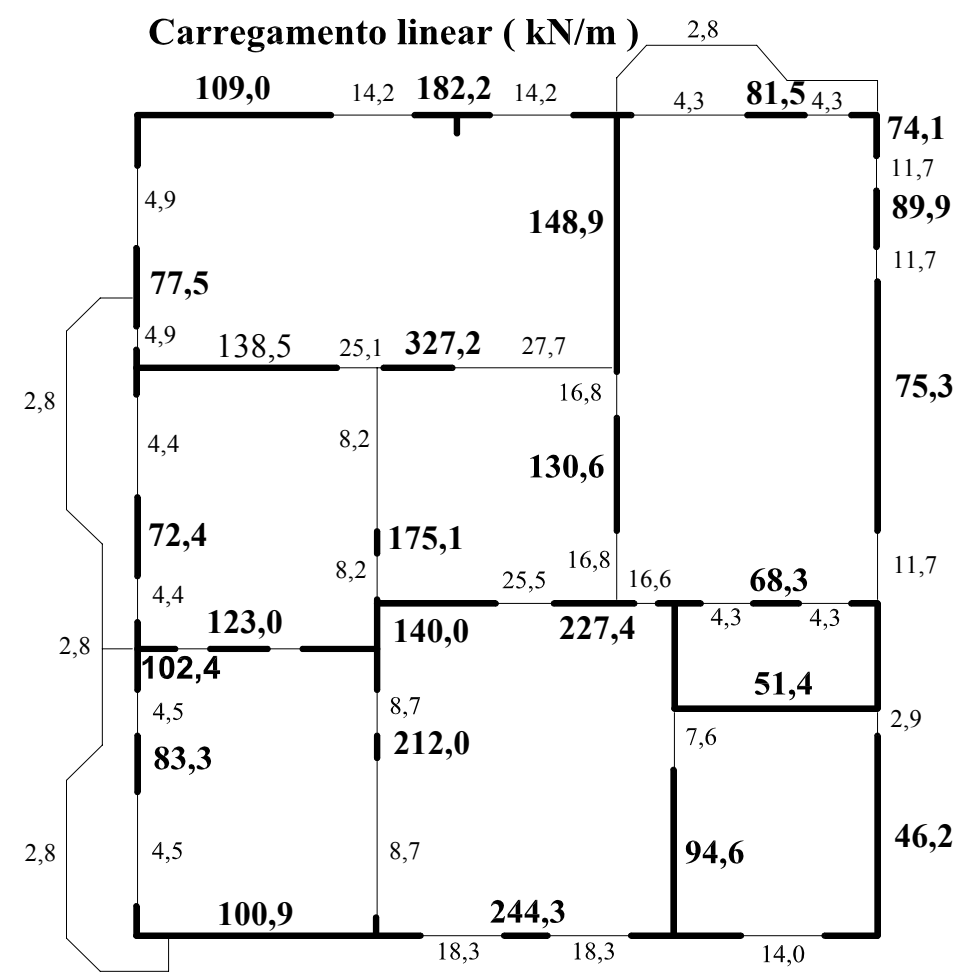

Figura 3.22 - Carregamento aplicado nas vigas de transição (kN/m). 


\subsubsection{VALORES DAS REAÇÕES NAS ESTACAS}

A figura 3.23 apresenta os resultados da análise no modelo considerado: as forças transversais e as normais atuantes nos elementos de fundação da estrutura.

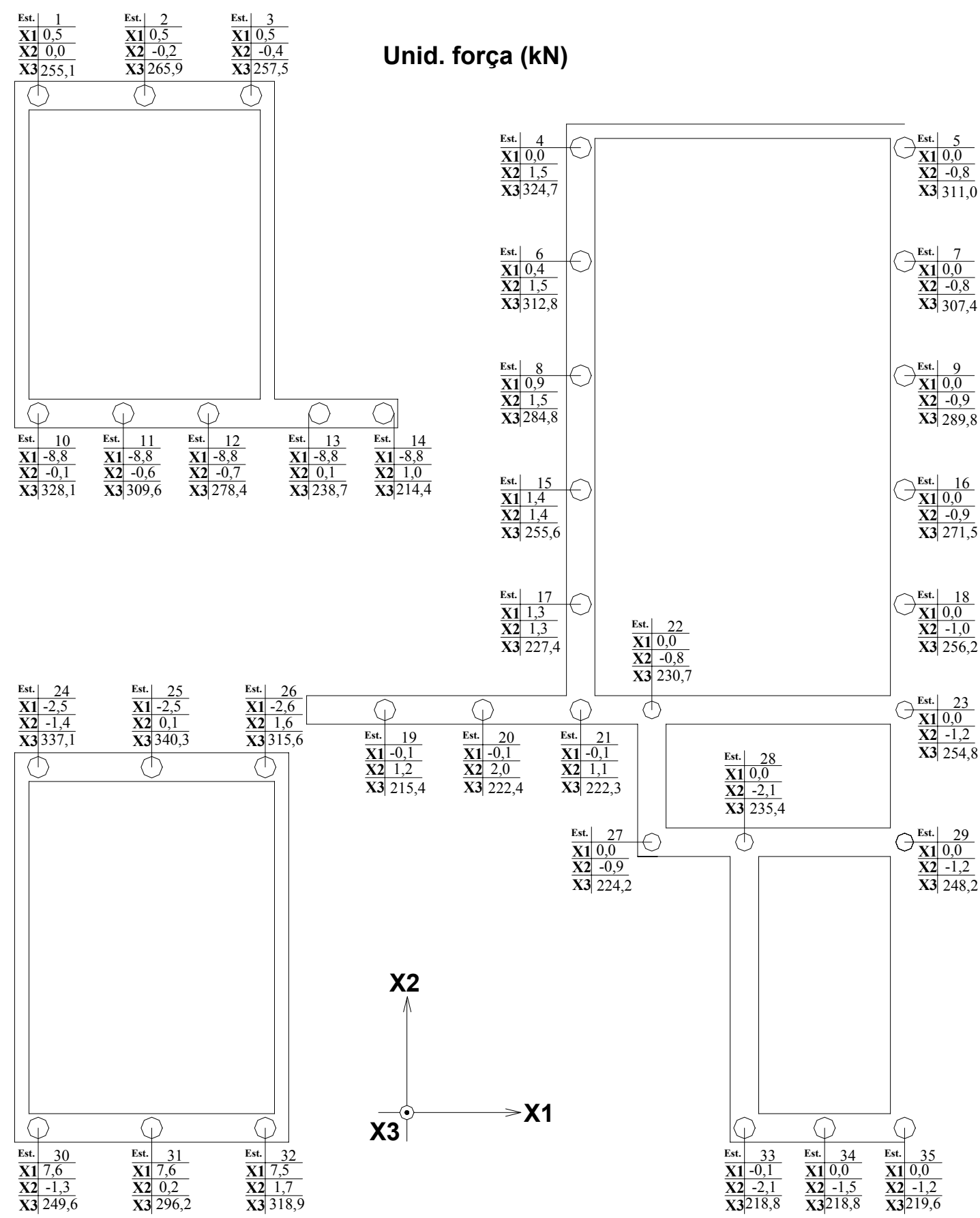

Figura 3.23 - Carregamento nas estacas $(k N)$. 


\subsection{EFEITO DO EMPUXO LATERAL NAS ESTACAS}

O presente item tem por objetivo apresentar quantitativamente que um grave erro de dimensionamento das estacas é cometido quando se desconsidera a atuação das forças horizontais exercidas pelo solo. A análise dos esforços ocorridos nas estacas, desconsiderando e considerando este carregamento, estão apresentados nos itens 3.6.1 e 3.6.2 respectivamente.

\subsubsection{VERIFICAÇÃO SEM CONSIDERAR O EMPUXO LATERAL}

Analisando as reações de apoio determinadas através do cálculo do modelo, foi selecionada a estaca $\mathrm{N}^{\mathrm{o}} 10$, por ser a mais carregada, para que seus esforços solicitantes fossem avaliados. Utilizou-se para essa verificação, o Processo de Riese e Matlock (1956), com as adaptações de Pfeil (1979).

Os esforços atuantes ao longo do fuste do elemento dependem da ligação com a estrutura e da reação lateral do solo. Foi adotado para a estaca em questão, como sendo livre no topo e não apoiada em rocha. A tabela 3.10 apresenta os carregamentos atuantes no elemento, de acordo com o ilustrado na figura 3.24.

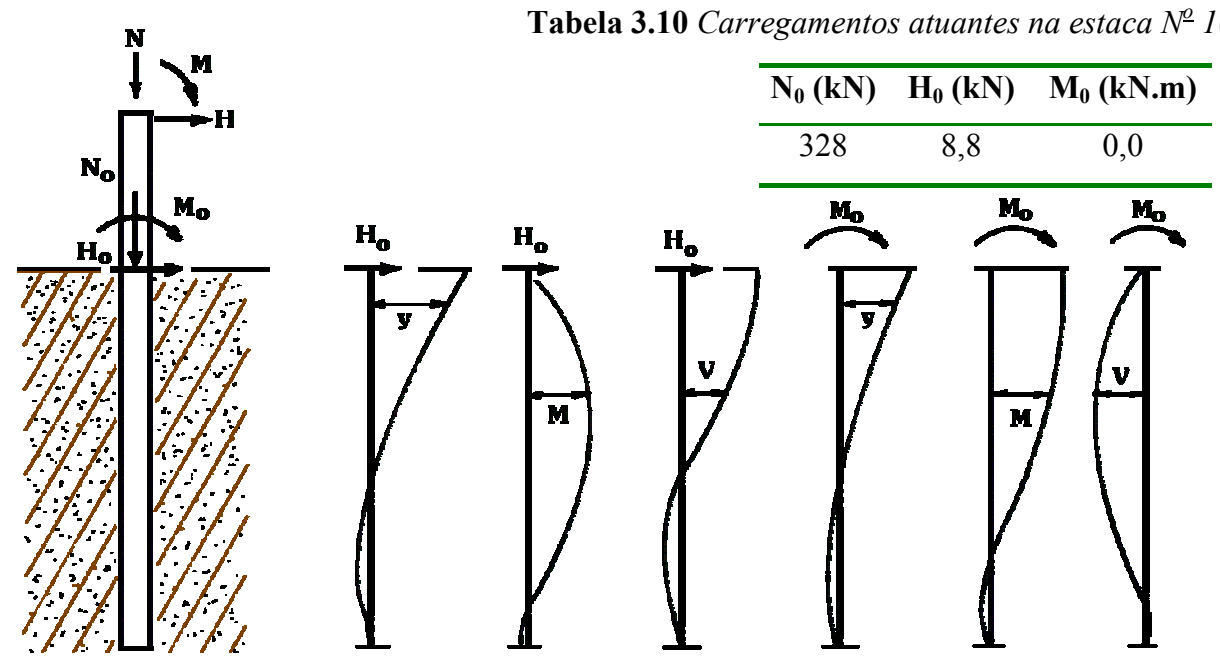

Figura 3.24 - Diagramas de deslocamentos, momentos fletores e cortantes atuantes na estaca. 


\section{a. Cálculo das características geométricas da estaca $\mathbf{n} \underline{\mathbf{O}} \mathbf{1 0}$}

Para os cálculos das características geométricas do elemento, foi adotada estaca executada com concreto de $20 \mathrm{MPa}$ de resistência à compressão e seção transversal circular com diâmetro de $30 \mathrm{~cm}$. Os valores apresentados na tabela 3.11 foram determinados através das equações 1, 2, 3 e 4 .

$$
\begin{aligned}
& \mathrm{A}_{\mathrm{c}}=\frac{\pi \cdot \mathrm{D}^{2}}{4} \\
& \mathrm{I}=\frac{\pi \cdot \mathrm{D}^{4}}{64} \\
& \mathrm{E}=0,85.5600 \sqrt{\mathrm{f}_{\mathrm{ck}}} \\
& \ell_{\mathrm{O}}=\sqrt[5]{\frac{\mathrm{El}}{\mathrm{C}_{\mathrm{y}}}} \\
& \mathrm{A}_{\mathrm{c}}-\text { área da seção transversal; } \\
& \mathrm{D}-\text { diâmetro da estaca (30 cm); } \\
& \mathrm{I}-\text { inércia da seção transversal; } \\
& \mathrm{E}-\text { módulo de elasticidade; } \\
& \mathrm{f}_{\mathrm{ck}}-\text { resistência característica do concreto à compressão (MPa) } \\
& \mathrm{L}-\text { comprimento da estaca; } \\
& \mathrm{l}_{0}-\text { comprimento elástico; } \\
& \mathrm{C}_{\mathrm{y}}-\text { coeficiente de reação horizontal do solo extraído da tabela } 3.12 .
\end{aligned}
$$

Tabela 3.11 Características geométricas da estaca $N^{\circ} 10$.

\begin{tabular}{ccccc}
\hline $\mathbf{A}_{\mathbf{c}}\left(\mathbf{m}^{\mathbf{2}}\right)$ & $\mathbf{L} \mathbf{( m )}$ & $\mathbf{I}\left(\mathbf{m}^{\mathbf{4}}\right)$ & $\mathbf{E}\left(\mathbf{k N} / \mathbf{m}^{2}\right)$ & $\mathbf{I}_{\mathbf{0}}(\mathbf{m})$ \\
\hline $7,07.10^{-2}$ & 25 & $3,976.10^{-4}$ & $21,287.10^{6}$ & 1,76 \\
\hline
\end{tabular}

Tabela 3.12 Coeficiente $C_{y}$ de reação horizontal do solo - Pfeil (1979).

\begin{tabular}{cccc}
\hline Tipo de solo & $\begin{array}{c}\mathbf{N}^{\mathbf{0}} \text { golpes do } \\
\text { amostrador padrão }\end{array}$ & $\mathbf{C}_{\mathbf{y}}\left(\mathbf{k N} / \mathbf{m}^{\mathbf{3}}\right)$ \\
\hline Areia média & $5-10$ & Solo seco ou úmido & Solo submerso \\
Areia compacta & $10-25$ & 2500 & 1500 \\
Areia muito compacta & $>25$ & 7000 & 5000 \\
Areia fofa, carga estática & 5 & 20000 & 12500 \\
Areia fofa, carga cíclica & $<5$ & & 1000 \\
Argila muito mole, carga estática & $<\mathbf{2}$ & $\mathbf{5 0 0}$ & 400 \\
Argila muito mole, carga cíclica & $<2$ & 300 & \\
Silte orgânico fofo & $<3$ & 300 & \\
Argila mole & $2-4$ & 1000 & \\
Argila média & $4-10$ & 2500 & \\
\hline
\end{tabular}




\section{b. Determinação dos esforços solicitantes}

Para determinar o momento fletor, a força cortante e os deslocamentos transversais, em uma determinada profundidade $z$, foram utilizadas as equações $5,6 \mathrm{e}$ 7 respectivamente.

$$
\begin{aligned}
& \mathrm{M}=\mathrm{C}_{\mathrm{H}} \cdot \mathrm{H}_{\mathrm{o}} \cdot l_{\mathrm{o}}+\mathrm{C}_{\mathrm{M}} \cdot \mathrm{M}_{\mathrm{o}} \\
& \mathrm{V}=\mathrm{C}_{\mathrm{H}}^{\prime} \cdot \mathrm{H}_{\mathrm{o}}+\mathrm{C}_{\mathrm{M}}^{\prime} \cdot \frac{\mathrm{M}_{\mathrm{o}}}{l_{\mathrm{o}}} \\
& \mathrm{y}=\mathrm{C}_{\mathrm{H}}^{\prime \prime} \cdot \frac{\mathrm{H}_{\mathrm{o}} \cdot \ell_{\mathrm{o}}^{3}}{\mathrm{EI}}+\mathrm{C}_{\mathrm{M}}^{\prime \prime} \cdot \frac{\mathrm{M}_{\mathrm{o}} \cdot \ell_{\mathrm{o}}^{2}}{\mathrm{EI}} \\
& \mathrm{C}_{\mathrm{H}}, \mathrm{C}_{\mathrm{M}}, \mathrm{C}_{\mathrm{H}}^{\prime}, \mathrm{C}_{\mathrm{M}}^{\prime}, \mathrm{C}_{\mathrm{H}}^{\prime \prime} \text { e } \mathrm{C}_{\mathrm{M}}^{\prime \prime} \text { são dados nas tabelas } 3.13,3.14 \text { e } 3.15 .
\end{aligned}
$$

\begin{tabular}{|c|c|c|c|c|c|c|c|c|c|c|}
\hline \multirow{3}{*}{$\mathbf{z} / \ell_{0}$} & \multicolumn{5}{|c|}{$\mathrm{C}_{\mathrm{H}}$} & & \multicolumn{4}{|c|}{$\mathrm{C}_{\mathrm{M}}$} \\
\hline & \multicolumn{5}{|c|}{$\ell / \ell_{0}$} & & \multicolumn{4}{|c|}{$\ell / \ell_{0}$} \\
\hline & 2 & 3 & 4 & 5 & 10 & 2 & 3 & 4 & 5 & 10 \\
\hline 0 & 0,0 & 0,0 & 0,0 & 0,0 & $\mathbf{0 , 0}$ & 1,0 & 1,0 & 1,0 & 1,0 & 1,0 \\
\hline 0,1 & 0,09 & 0,09 & 0,09 & 0,09 & 0,09 & 1,0 & 1,0 & 1,0 & 1,0 & 1,0 \\
\hline 0,2 & 0,20 & 0,20 & 0,20 & 0,20 & 0,20 & 1,0 & 1,0 & 1,0 & 1,0 & 1,0 \\
\hline 0,3 & 0,29 & 0,29 & 0,29 & 0,29 & 0,29 & 0,99 & 0,99 & 0,99 & 0,99 & 0,99 \\
\hline 0,4 & 0,38 & 0,38 & 0,38 & 0,38 & $\mathbf{0 , 3 8}$ & 0,97 & 0,98 & 0,99 & 0,99 & 0,99 \\
\hline 0,5 & 0,43 & 0,45 & 0,45 & 0,45 & 0,45 & 0,95 & 0,97 & 0,98 & 0,98 & 0,98 \\
\hline 0,6 & 0,47 & 0,53 & 0,53 & 0,53 & $\mathbf{0 , 5 3}$ & 0,91 & 0,95 & 0,96 & 0,96 & 0,96 \\
\hline 0,7 & 0,50 & 0,59 & 0,60 & 0,60 & 0,60 & 0,87 & 0,93 & 0,94 & 0,94 & 0,94 \\
\hline 0,8 & 0,52 & 0,63 & 0,65 & 0,65 & 0,65 & 0,81 & 0,91 & 0,92 & 0,91 & 0,91 \\
\hline 0,9 & 0,51 & 0,66 & 0,69 & 0,69 & 0,69 & 0,75 & 0,87 & 0,89 & 0,88 & 0,88 \\
\hline 1,0 & 0,49 & 0,69 & 0,73 & 0,72 & 0,72 & 0,68 & 0,84 & 0,86 & 0,85 & 0,85 \\
\hline 1,1 & 0,46 & 0,70 & 0,76 & 0,75 & 0,75 & 0,60 & 0,79 & 0,83 & 0,81 & 0,81 \\
\hline 1,2 & 0,41 & 0,71 & 0,78 & 0,76 & 0,76 & 0,51 & 0,74 & 0,78 & 0,77 & 0,77 \\
\hline 1,3 & 0,36 & 0,70 & 0,78 & 0,77 & 0,77 & 0,42 & 0,70 & 0,74 & 0,73 & 0,73 \\
\hline 1,4 & 0,29 & 0,63 & 0,78 & 0,77 & 0,77 & 0,33 & 0,65 & 0,70 & 0,69 & 0,69 \\
\hline 1,5 & 0,22 & 0,65 & 0,77 & 0,76 & 0,76 & 0,25 & 0,60 & 0,66 & 0,64 & 0,64 \\
\hline 1,6 & 0,16 & 0,62 & 0,75 & 0,74 & 0,74 & 0,17 & 0,54 & 0,60 & 0,59 & 0,59 \\
\hline
\end{tabular}

Pode-se observar nos gráficos das figuras $3.25,3.26$ e 3.27 os diagramas calculados ao longo do fuste da estaca.

Tabela 3.13 Elementos livres no topo e não apoiados em rocha: valores de $C_{H}$ e $C_{M}$ - Pfeil (1979). 
Tabela 3.14 Elementos livres no topo e não apoiados em rocha: valores de $C^{\prime}{ }_{\mathrm{H}}$ e $C^{\prime}{ }_{\mathrm{M}}$ - Pfeil (1979).

\begin{tabular}{|c|c|c|c|c|c|c|c|c|c|c|}
\hline \multirow{3}{*}{$\mathbf{z} / \ell_{0}$} & \multicolumn{5}{|c|}{$\mathrm{C}_{\mathrm{H}}^{\prime}$} & \multicolumn{5}{|c|}{$C^{\prime}{ }_{M}$} \\
\hline & \multicolumn{5}{|c|}{$\ell / \ell_{0}$} & \multicolumn{5}{|c|}{$\ell / \ell_{0}$} \\
\hline & 2 & 3 & 4 & 5 & 10 & 2 & 3 & 4 & 5 & 10 \\
\hline 0 & 1,0 & 1,0 & 1,0 & 1,0 & 1,0 & 0,0 & 0,0 & 0,0 & 0,0 & 0,0 \\
\hline 0,1 & 0,98 & 0,98 & 0,98 & 0,98 & $\mathbf{0 , 9 8}$ & $-0,02$ & $-0,02$ & $-0,02$ & $-0,02$ & $-0,02$ \\
\hline 0,2 & 0,92 & 0,95 & 0,96 & 0,96 & 0,96 & $-0,06$ & $-0,03$ & $-0,02$ & $-0,03$ & $-0,03$ \\
\hline 0,3 & 0,82 & 0,90 & 0,90 & 0,90 & $\mathbf{0 , 9 0}$ & $-0,13$ & $-0,07$ & $-0,06$ & $-0,05$ & $-0,05$ \\
\hline 0,4 & 0,70 & 0,82 & 0,84 & 0,84 & 0,84 & $-0,20$ & $-0,11$ & $-0,09$ & $-0,09$ & $-0,09$ \\
\hline 0,5 & 0,56 & 0,74 & 0,76 & 0,78 & 0,78 & $-0,30$ & $-0,15$ & $-0,12$ & $-0,13$ & $-0,13$ \\
\hline 0,6 & 0,40 & 0,64 & 0,68 & 0,68 & 0,68 & $-0,40$ & $-0,20$ & $-0,17$ & $-0,18$ & $-0,18$ \\
\hline 0,7 & 0,22 & 0,52 & 0,59 & 0,59 & $\mathbf{0 , 5 9}$ & $-0,50$ & $-0,25$ & $-0,22$ & $-0,23$ & $-0,23$ \\
\hline 0,8 & 0,06 & 0,42 & 0,50 & 0,50 & $\mathbf{0 , 5 0}$ & $-0,60$ & $-0,30$ & $-0,26$ & $-0,27$ & $-0,27$ \\
\hline 0,9 & $-0,1$ & 0,30 & 0,39 & 0,39 & $\mathbf{0 , 3 9}$ & $-0,68$ & $-0,35$ & $-0,31$ & $-0,32$ & $-0,32$ \\
\hline 1,0 & $-0,24$ & 0,20 & 0,30 & 0,30 & $\mathbf{0 , 3 0}$ & $-0,76$ & $-0,40$ & $-0,35$ & $-0,35$ & $-0,35$ \\
\hline 1,1 & $-0,40$ & 0,08 & 0,19 & 0,19 & $\mathbf{0 , 1 9}$ & $-0,81$ & $-0,44$ & $-0,38$ & $-0,38$ & $-0,38$ \\
\hline 1,2 & $-0,50$ & $-0,01$ & 0,10 & 0,10 & $\mathbf{0 , 1 0}$ & $-0,86$ & $-0,47$ & $-0,41$ & $-0,41$ & $-0,41$ \\
\hline 1,3 & $-0,60$ & $-0,12$ & 0,01 & 0,01 & $\mathbf{0 , 0 1}$ & $-0,88$ & $-0,50$ & $-0,44$ & $-0,44$ & $-0,44$ \\
\hline 1,4 & $-0,66$ & $-0,22$ & $-0,06$ & $-0,06$ & $-0,06$ & $-0,86$ & $-0,53$ & $-0,46$ & $-0,46$ & $-0,46$ \\
\hline 1,5 & $-0,67$ & $-0,30$ & $-0,14$ & $-0,12$ & $-0,12$ & $-0,82$ & $-0,54$ & $-0,47$ & $-0,47$ & $-0,47$ \\
\hline 1,6 & $-0,64$ & $-0,38$ & $-0,22$ & $-0,20$ & $-0,20$ & $-0,74$ & $-0,56$ & $-0,48$ & $-0,48$ & $-0,48$ \\
\hline
\end{tabular}

Tabela 3.15 Elementos livres no topo e não apoiados em rocha: valores de $C{ }_{H}$ e $C{ }_{M}$ - Pfeil (1979).

\begin{tabular}{|c|c|c|c|c|c|c|c|c|c|c|}
\hline \multirow{3}{*}{$\mathbf{z} / \ell_{0}$} & \multicolumn{5}{|c|}{ C" ${ }_{H}$} & \multicolumn{5}{|c|}{$C{ }_{M}$} \\
\hline & \multicolumn{5}{|c|}{$\ell / \ell_{0}$} & \multicolumn{5}{|c|}{$\ell / \ell_{0}$} \\
\hline & 2 & 3 & 4 & 5 & 10 & 2 & 3 & 4 & 5 & 10 \\
\hline 0 & 4,75 & 2,70 & 2,45 & 2,40 & 2,40 & 3,4 & 1,75 & 1,62 & 1,62 & 1,62 \\
\hline 0,1 & 4,40 & 2,50 & 2,33 & 2,23 & 2,23 & 3,1 & 1,60 & 1,45 & 1,45 & 1,45 \\
\hline 0,2 & 4,05 & 2,35 & 2,15 & 2,07 & 2,07 & 2,77 & 1,43 & 1,30 & 1,30 & 1,30 \\
\hline 0,3 & 3,70 & 2,17 & 1,95 & 1,92 & 1,92 & 2,50 & 1,27 & 1,14 & 1,14 & 1,14 \\
\hline 0,4 & 3,40 & 2,0 & 1,83 & 1,75 & 1,75 & 2,20 & 1,13 & 1,0 & 1,0 & 1,0 \\
\hline 0,5 & 3,05 & 1,95 & 1,67 & 1,63 & 1,63 & 1,95 & 0,97 & 0,87 & 0,87 & 0,87 \\
\hline 0,6 & 2,70 & 1,67 & 1,53 & 1,47 & 1,47 & 1,67 & 0,85 & 0,75 & 0,75 & 0,75 \\
\hline 0,7 & 2,35 & 1,57 & 1,37 & 1,33 & 1,33 & 1,40 & 0,73 & 0,64 & 0,64 & 0,64 \\
\hline 0,8 & 2,05 & 1,37 & 1,25 & 1,20 & 1,20 & 1,15 & 0,63 & 0,54 & 0,54 & 0,54 \\
\hline 0,9 & 1,75 & 1,23 & 1,10 & 1,07 & 1,07 & 0,90 & 0,53 & 0,45 & 0,45 & 0,45 \\
\hline 1,0 & 1,45 & 1,10 & 1,0 & 0,95 & 0,95 & 0,70 & 0,43 & 0,36 & 0,36 & 0,36 \\
\hline 1,1 & 1,15 & 0,95 & 0,87 & 0,83 & $\mathbf{0 , 8 3}$ & 0,45 & 0,35 & 0,28 & 0,28 & 0,28 \\
\hline 1,2 & 0,85 & 0,85 & 0,75 & 0,70 & 0,70 & 0,20 & 0,28 & 0,22 & 0,22 & 0,22 \\
\hline 1,3 & 0,55 & 0,73 & 0,65 & 0,61 & 0,61 & 0,0 & 0,20 & 0,15 & 0,15 & 0,15 \\
\hline 1,4 & 0,25 & 0,67 & 0,55 & 0,51 & 0,51 & $-0,20$ & 0,15 & 0,11 & 0,11 & 0,11 \\
\hline 1,5 & 0,0 & 0,50 & 0,45 & 0,43 & 0,43 & $-0,40$ & 0,10 & 0,07 & 0,07 & 0,07 \\
\hline 1,6 & $-0,3$ & 0,40 & 0,38 & 0,30 & $\mathbf{0 , 3 0}$ & $-0,60$ & 0,05 & 0,03 & 0,03 & 0,03 \\
\hline
\end{tabular}




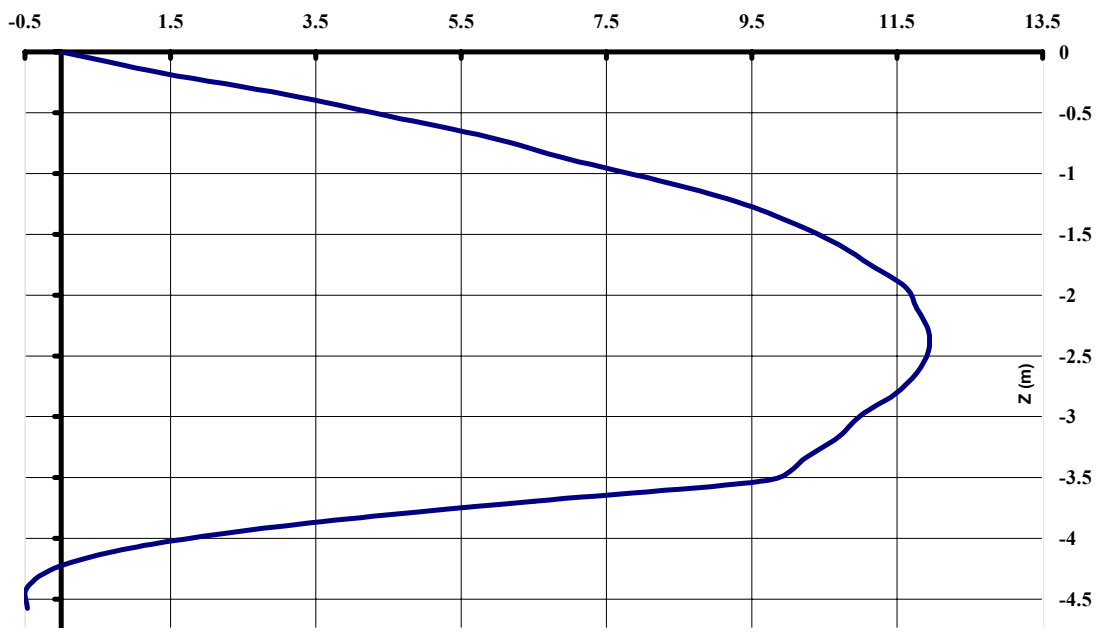

Figura 3.25 - Diagramas de momento fletor da estaca $n^{\circ} 10(\mathrm{kN} . \mathrm{m})$.

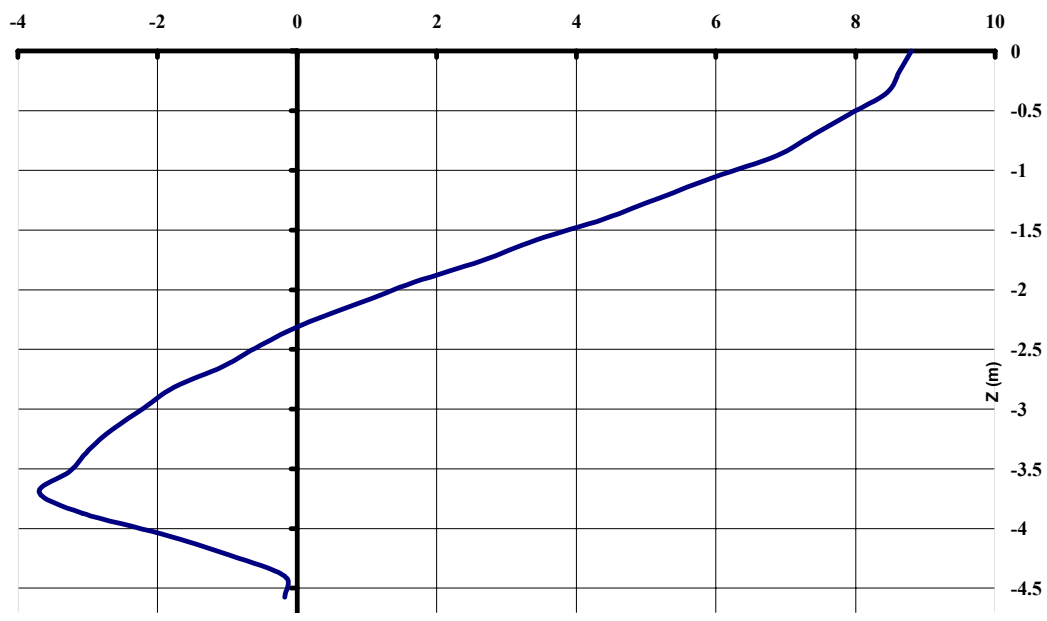

Figura 3.26 - Diagramas de força cortante da estaca $n^{-} 10(\mathrm{kN})$.

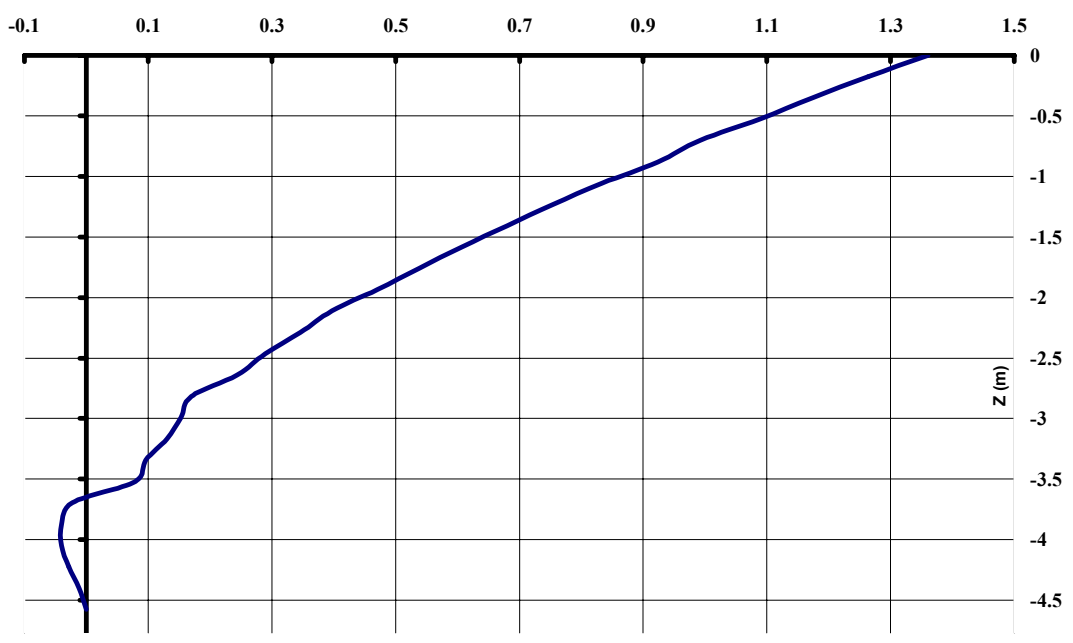

Figura 3.27 - Deslocamento horizontal da estaca $n^{\circ} 10(\mathrm{~cm})$. 


\section{c. Verificação do cisalhamento}

Para a verificação do cisalhamento foi adotado o procedimento do ACI343R (1981), onde a tensão de cisalhamento de cálculo $\tau_{\mathrm{d}}$ (Equação 8) é comparada com a tensão última $\tau_{u}$ dada pela Equação 9.

$$
\begin{aligned}
\tau_{d} & =\frac{V_{d}}{A_{c}} \\
\tau_{u} & =0,85 \cdot 2 \cdot \sqrt{0,007 \cdot f_{c k}} \\
\mathrm{~V}_{\mathrm{d}} & - \text { máxima força cortante de cálculo; } \\
\mathrm{f}_{\mathrm{ck}} & - \text { resistência característica do concreto à compressão }(\mathrm{MPa})
\end{aligned}
$$

$$
\left\{\begin{array}{c}
\tau_{d}=\frac{8,8 \cdot 1,4}{7,07 \cdot 10^{-2}}=0,174 \mathrm{MPa} \\
\tau_{u}=0,85 \cdot 2 \cdot \sqrt{0,007 \cdot 20}=0,636 \mathrm{MPa}
\end{array}\right\} \therefore \tau_{d}<\tau_{u}
$$

Substituindo os valores nas equações 8 e 9 foi concluído que a estaca suporta os esforços cisalhantes atuantes nela.

\section{d. Dimensionamento da armadura longitudinal}

Para o dimensionamento da armadura longitudinal da estaca, foi adotado um cobrimento de 4,5 cm, por ela estar imersa em ambiente considerado agressivo. Essa armadura foi dimensionada através das equações 10 e 11, no qual os valores de $\omega$ estão apresentados na figura 3.28 extraída de Montoya (2000).

$$
\begin{aligned}
& \omega=\frac{A_{s} \cdot f_{y d}}{A_{c} \cdot f_{c d}} \\
& f_{c d}=\frac{f_{c k}}{\gamma_{c}}
\end{aligned}
$$

- $\mathrm{A}_{\mathrm{s}}$ área da armadura longitudinal;

- $\mathrm{A}_{\mathrm{c}}$ área da seção do fuste;

- $f_{y d}$ resistência de cálculo de escoamento do aço;

- $\mathrm{f}_{\mathrm{cd}}$ resistência de cálculo do concreto;

$-\gamma_{\mathrm{c}}=1,6$ coeficiente de segurança para concretagem de estacas 


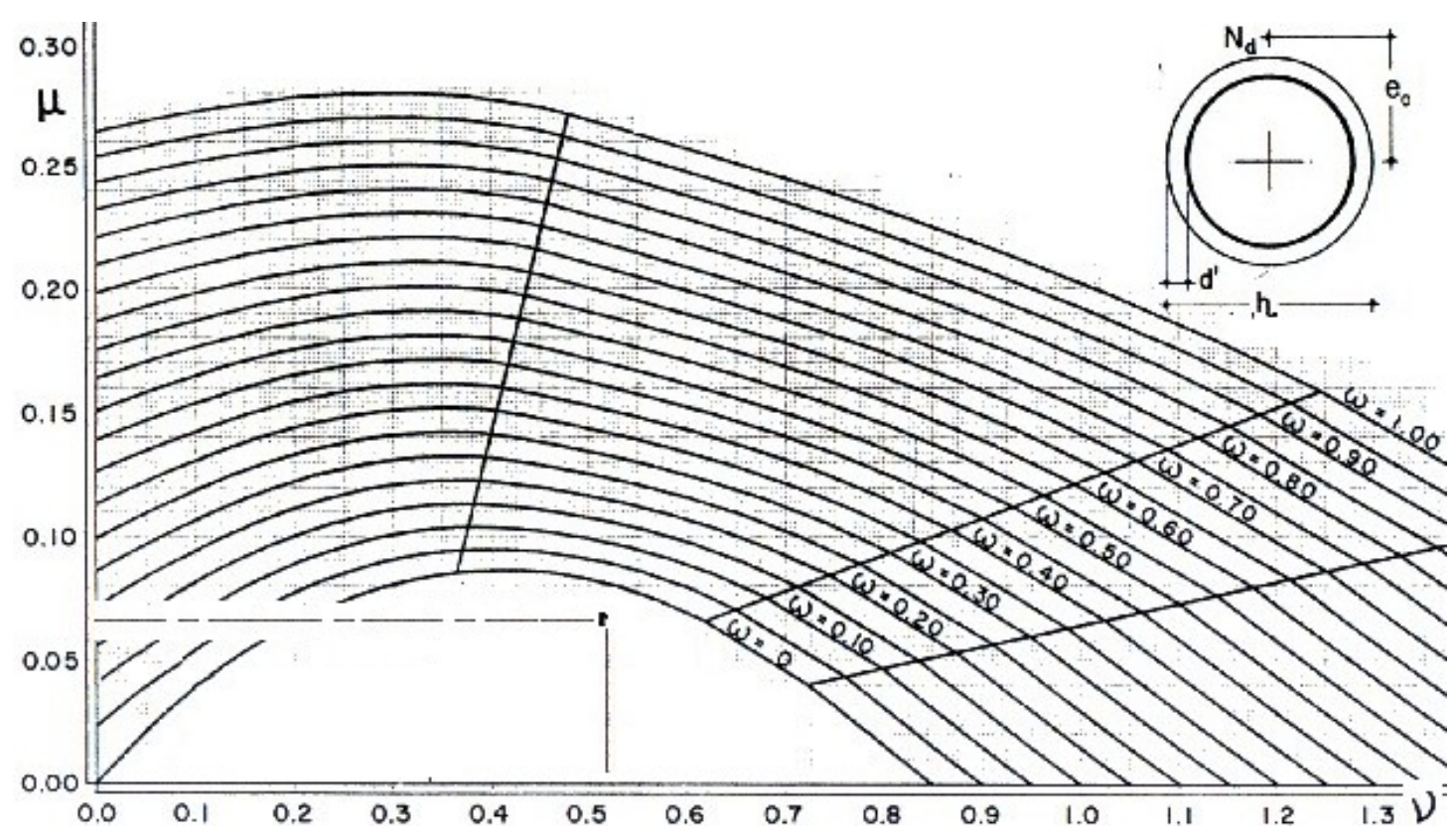

Figura 3.28 - Valores de $\omega$ para d' $=0,15$ - Montoya (2000).

$$
\begin{aligned}
& u=\frac{N_{d}}{A_{c} \cdot f_{c d}} \\
& \mu=\frac{M_{d}}{A_{c} \cdot h \cdot f_{c d}}
\end{aligned}
$$

$$
\left\{\begin{array}{c}
v=\frac{1,4 \cdot 328}{0,0707 \cdot \frac{20 \cdot 10^{3}}{1,6}}=0,52 \\
\mu=\frac{1,4 \cdot 11,8}{0,0707 \cdot 0,3 \cdot \frac{20 \cdot 10^{3}}{1,6}}=0,062
\end{array}\right\} \Rightarrow \omega=0,0 \therefore \mathrm{A}_{\mathrm{s}} \text { mínimo }
$$

Substituindo os valores nas equações 12 e 13 foi concluído que $\omega=0$ e, conseqüentemente, a armadura mínima é suficiente para suportar os esforços de flexo-compressão na estaca. 


\subsubsection{VERIFICAÇÃO CONSIDERANDO O EMPUXO LATERAL}

A estaca $n^{0} 2$ foi selecionada para verificar os efeitos do carregamento lateral. Ela foi escolhida por estar mais próxima ao pé do aterro e, conseqüentemente, sobre maior efeito do empuxo lateral. As medidas do perfil do solo, onde está situado essa estaca, foram estabelecidas levando-se em consideração os resultados da sondagem SP-05. A figura 3.29 ilustra a situação da estaca.

Neste item serão abordados dois métodos distintos para avaliar a magnitude da pressão horizontal - Tschebotarioff e método de Beer e Wallays.

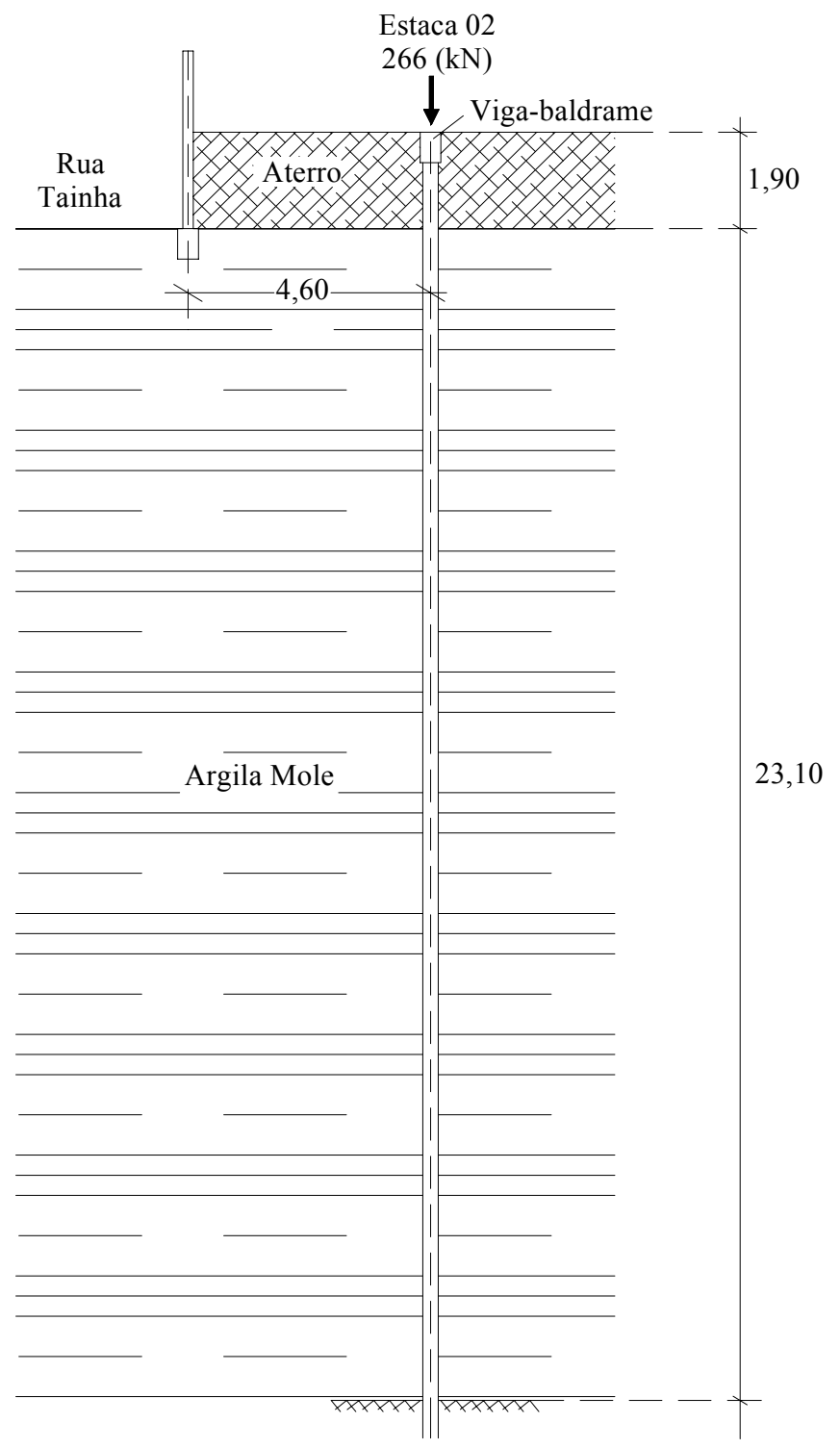

Figura 3.29 - Vista em corte da estaca $n^{-} 02$. 


\section{a. Método de Tschebotarioff}

Segundo Tschebotarioff, a distribuição das pressões laterais que atuam sobre as estacas é função dos seguintes parâmetros:

- $\quad$ Altura do aterro sobre a camada de solo mole;

- $\quad$ Peso específico do material de aterro;

- Características da argila;

- $\quad$ Rigidez das estacas;

- $\quad$ Geometria do estaqueamento;

- $\quad$ Distância das estacas ao pé do aterro;

- Interação das sucessivas linhas de estacas e o terreno.

$\mathrm{Na}$ falta de dados experimentais o autor recomenda que se considere um diagrama de pressões triangular com valor máximo à meia altura da camada de solo mole (figura 3.13), sendo este valor máximo determinado segundo a equação 14 .

$\mathrm{P}_{\mathrm{h}}=0,4 \cdot \gamma_{\mathrm{k}} \cdot \mathrm{H}$

- $\mathrm{P}_{\mathrm{h}}$ valor máximo de pressão horizontal exercida na estaca;

- $\gamma_{\mathrm{k}}$ peso específico do material de aterro (adotado $18 \mathrm{kN} / \mathrm{m}^{3}$ );

- $\mathrm{H}$ altura do aterro.

Para determinar o carregamento por unidade de comprimento, basta multiplicar o resultado da equação 14 pelo diâmetro da estaca.

$$
\mathrm{P}_{\mathrm{h}}=0,4 \cdot 18 \cdot 1,9 \Rightarrow \mathrm{P}_{\mathrm{h}}=13,68 \frac{\mathrm{kN}}{\mathrm{m}^{2}} \quad \mathrm{p}_{\mathrm{h}}=13,68 \cdot 0,30 \Rightarrow \mathrm{p}_{\mathrm{h}}=4,11 \frac{\mathrm{kN}}{\mathrm{m}}
$$

O modelo adotado para o cálculo foi: estaca engastada na base e apoiada em base elástica $(\mathrm{k}=3000 \mathrm{kN} / \mathrm{m})$ à meia altura do aterro, como mostra a figura 3.30 .

Os resultados dos esforços atuantes e deslocamentos horizontais, segundo o método proposto por Tschebotarioff, estão apresentados nas figuras 3.31, 3.32 e 3.33 respectivamente. 


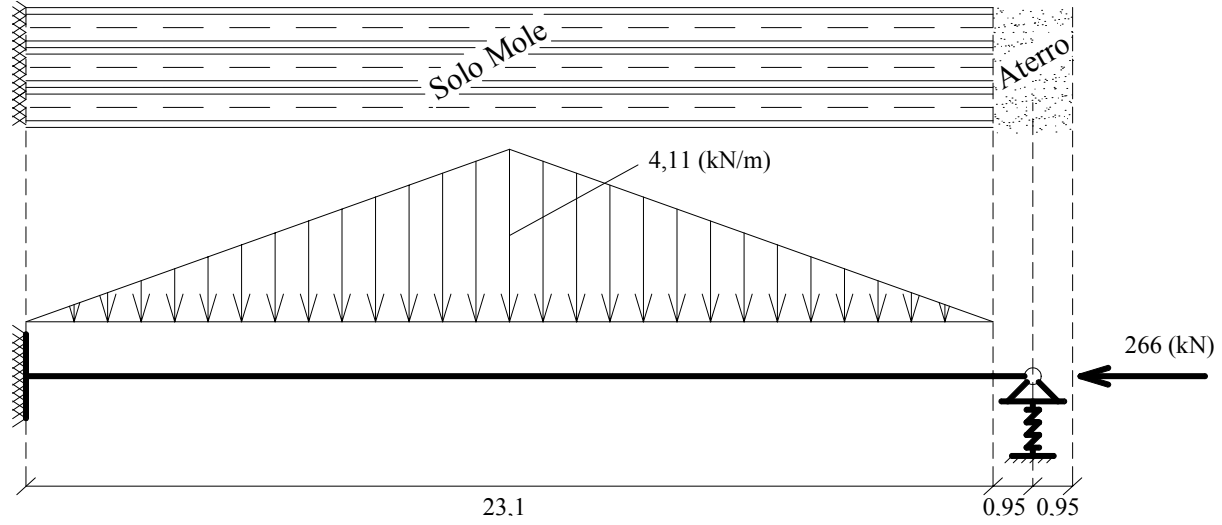

Figura 3.30 - Modelo de cálculo segundo Tschebotarioff.

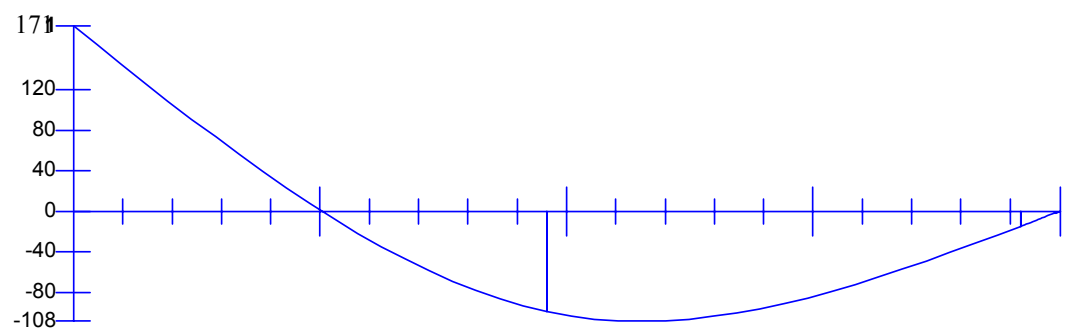

Figura 3.31 - Diagrama de momento fletor ( $k N$. $m$ ).

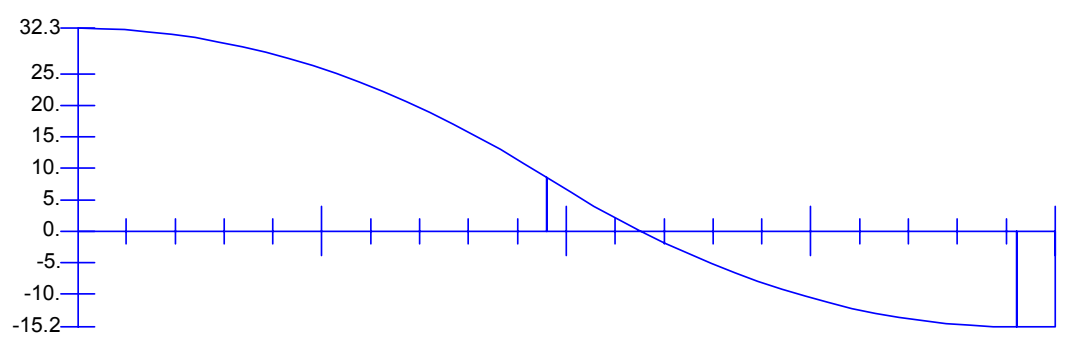

Figura 3.32 - Diagrama da força cortante $(k N)$.

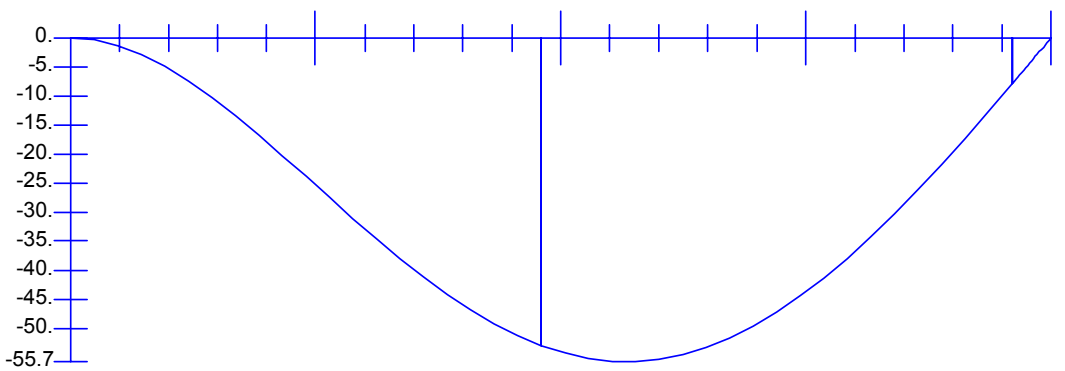

Figura 3.33 - Deslocamento horizontal (cm). 
- $\quad$ Verificação do cisalhamento:

Máxima cortante $-\mathrm{V}_{\max }=32,2 \mathrm{kN}$

$$
\left\{\begin{array}{c}
\tau_{d}=\frac{32,2 \cdot 1,4}{7,07 \cdot 10^{-2}}=0,63 \mathrm{MPa} \\
\tau_{u}=0,85 \cdot 2 \cdot \sqrt{0,007 \cdot 20}=0,636 \mathrm{MPa}
\end{array}\right\} \therefore \tau_{d}>\tau_{u}
$$

Levando-se em conta os cálculos segundo as equações 8 e 9, a tensão cisalhante atuante na seção está no limite de sua capacidade.

- $\quad$ Cálculo da armadura longitudinal:

Máximo momento fletor $-\mathrm{M}_{\max }=108 \mathrm{kN} . \mathrm{m}$

Força normal de compressão na estaca $-\mathrm{N}=266 \mathrm{kN}$

$$
\left.\begin{array}{c}
v=\frac{1,4 \cdot 266}{0,0707 \cdot \frac{20 \cdot 10^{3}}{1,6}}=0,42 \\
\mu=\frac{1,4 \cdot 108}{0,0707 \cdot 0,3 \cdot \frac{20 \cdot 10^{3}}{1,6}}=0,57
\end{array}\right\} \Rightarrow \omega \cong 2,8
$$

Para o caso analisado, $57 \mathrm{~cm}^{2}$ é a área da armadura longitudinal necessária para resistir o esforço de flexão atuante na estaca. 


\section{b. Método de Beer e Wallays}

O posicionamento da estaca em relação ao aterro tem grande influência no valor da pressão horizontal. O método proposto por Tschebotarioff, abordado no item 3.6.2-a, é aplicado para estacas localizadas no pé do talude e, portanto, desconsidera o alívio das pressões horizontais quando a fundação está localizada no interior do aterro ou fora dele.

O método proposto por Beer e Wallays considera o posicionamento da estaca em relação ao aterro e apresenta valores para o empuxo horizontal em diversas situações de carregamento vertical. O diagrama sugerido pelos autores desse empuxo é uniforme e com valor determinado através da equação 15.

$$
\mathrm{P}_{\mathrm{h}}=\left(\frac{\alpha-\frac{\phi}{2}}{\frac{\pi}{2}-\frac{\phi}{2}}\right) \cdot \mathrm{P}_{\mathrm{v}}
$$

- $\mathrm{P}_{\mathrm{h}}$ pressão horizontal exercida na estaca;

- $\propto$ ângulo indicado na figura 3.34;

- $\phi$ ângulo de atrito interno do aterro (adotado $20^{\circ}$ );

- $\mathrm{P}_{\mathrm{v}}$ pressão vertical determinada através da equação 16.

$$
\begin{aligned}
& P_{v}=\gamma_{k} \cdot H \\
& H_{f}=H \cdot \frac{\gamma_{k}}{\gamma_{s}}
\end{aligned}
$$

- $\gamma_{\mathrm{k}}$ peso específico do aterro utilizado pelos autores do método, na formulação das equações $\left(18 \mathrm{kN} / \mathrm{m}^{3}\right)$;

- $\gamma_{\mathrm{s}}$ peso específico real do aterro analisado (adotado $15 \mathrm{kN} / \mathrm{m}^{3}$ );

- H altura do aterro;

- $\mathrm{H}_{\mathrm{f}}$ altura fictícia do aterro indicada na figura 3.34. 


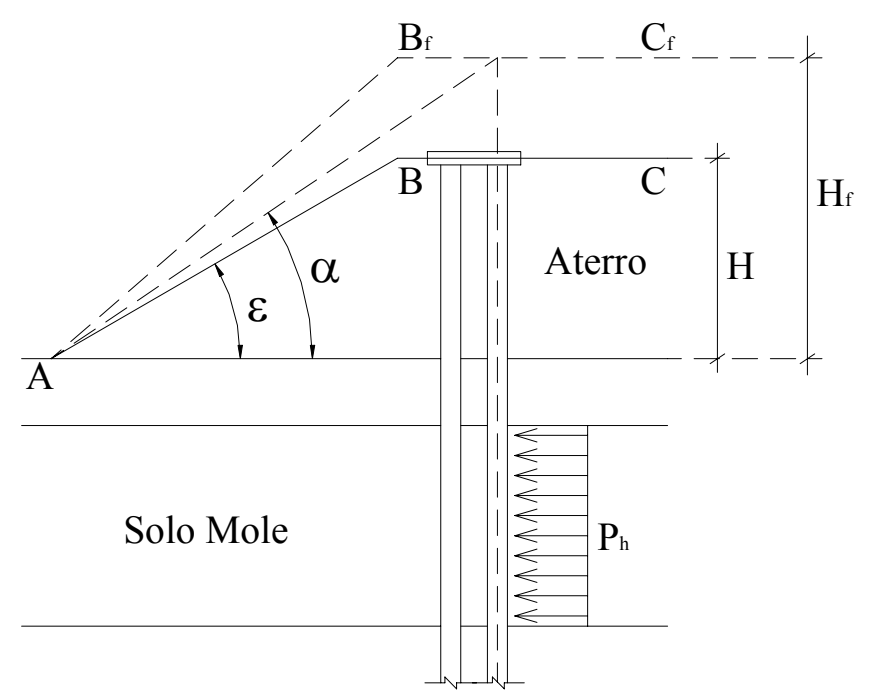

Figura 3.34 - Pressão lateral em estacas posicionadas no interior do aterro - Beer e Wallays (1972).

Adaptando o método proposto para o caso da estaca analisada, foram determinados:

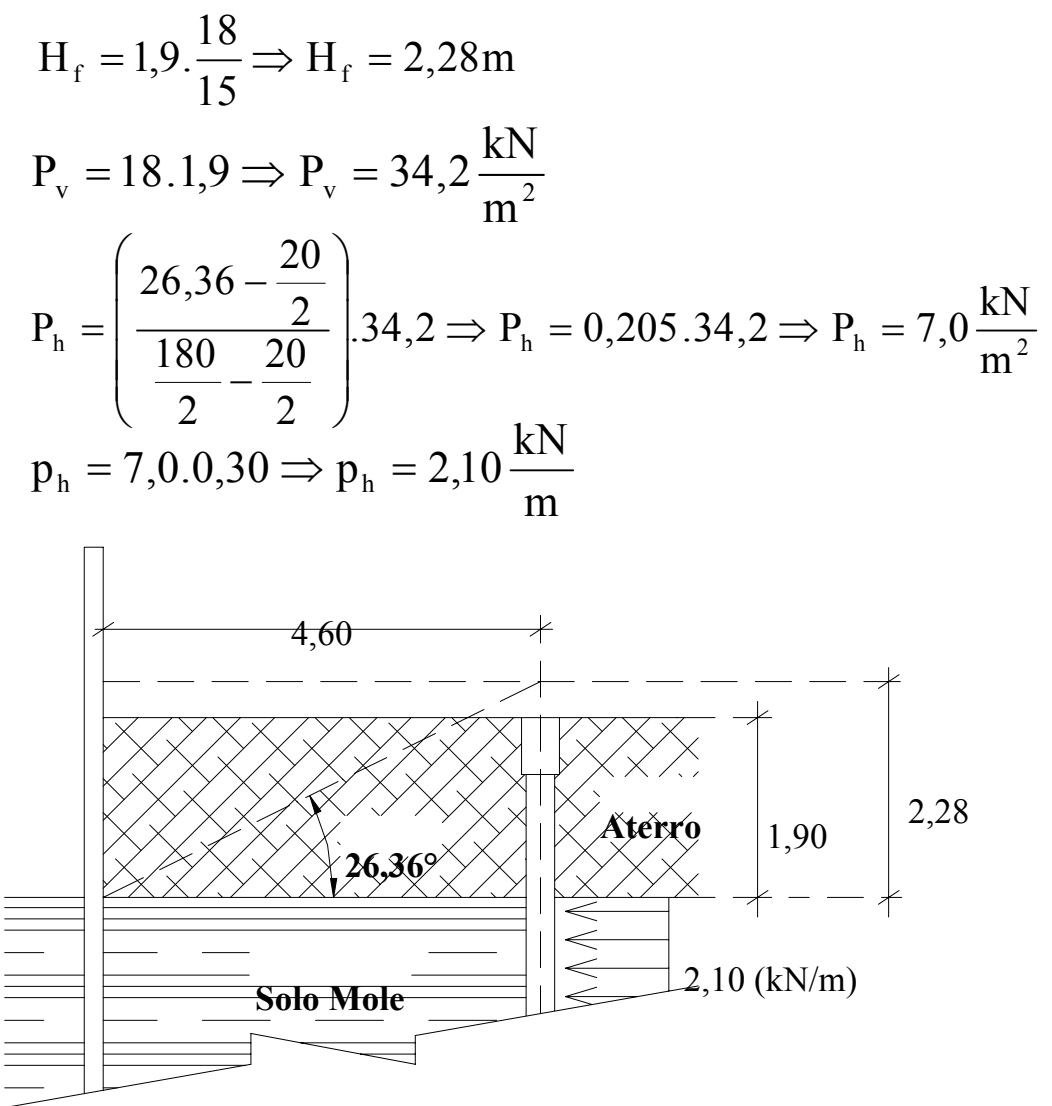

Figura 3.35 - Geometria do caso analisado. 
Os resultados dos esforços atuantes e deslocamentos horizontais ocorridos na estaca, segundo o método proposto, estão apresentados nas figuras 3.37, 3.38 e 3.39 respectivamente.

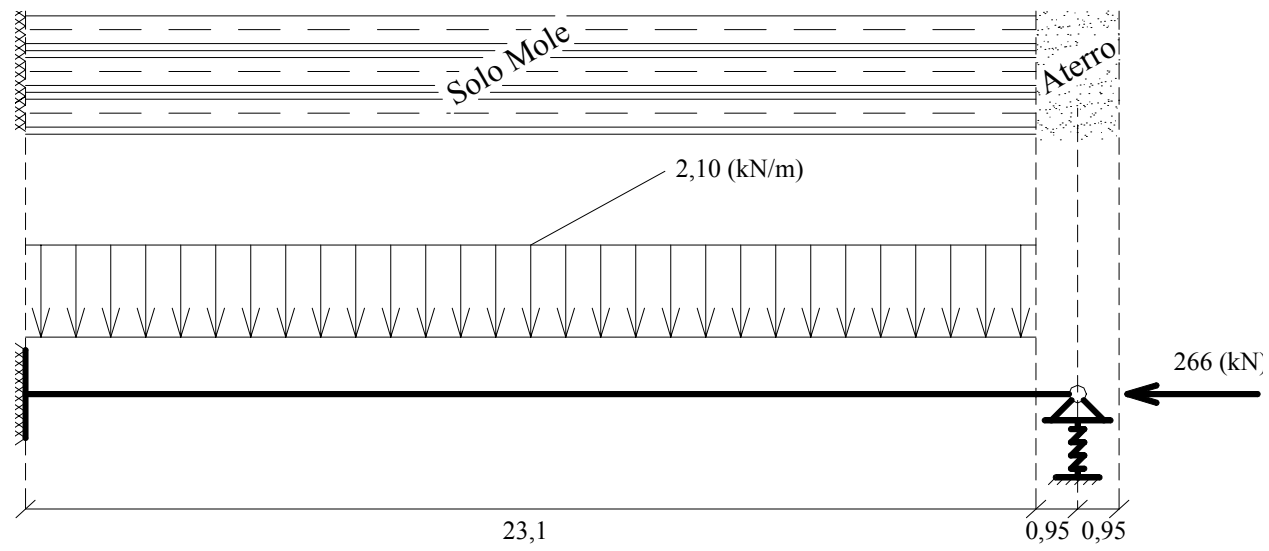

Figura 3.36 - Modelo calculado segundo Beer e Wallays.

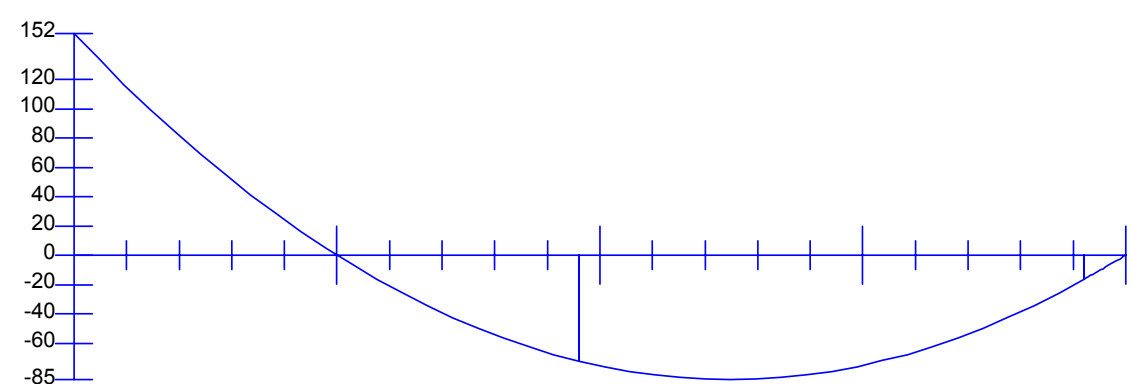

Figura 3.37 - Diagrama de momento fletor (kN.m).

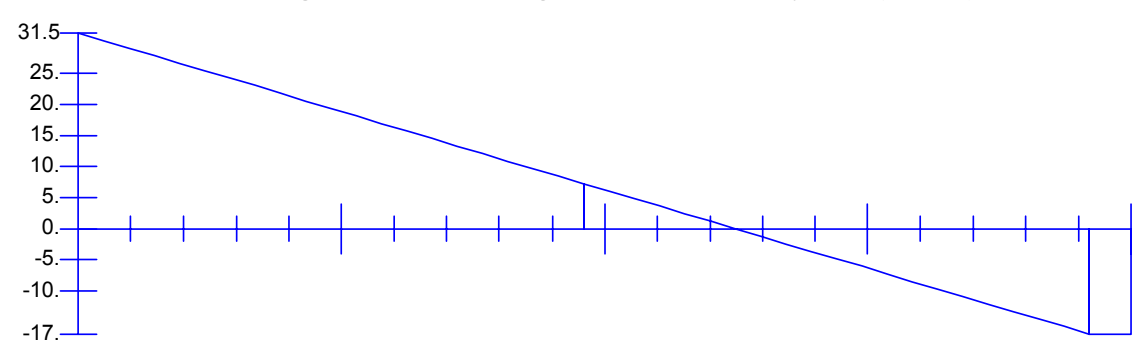

Figura 3.38 - Diagrama da força cortante $(k N)$.

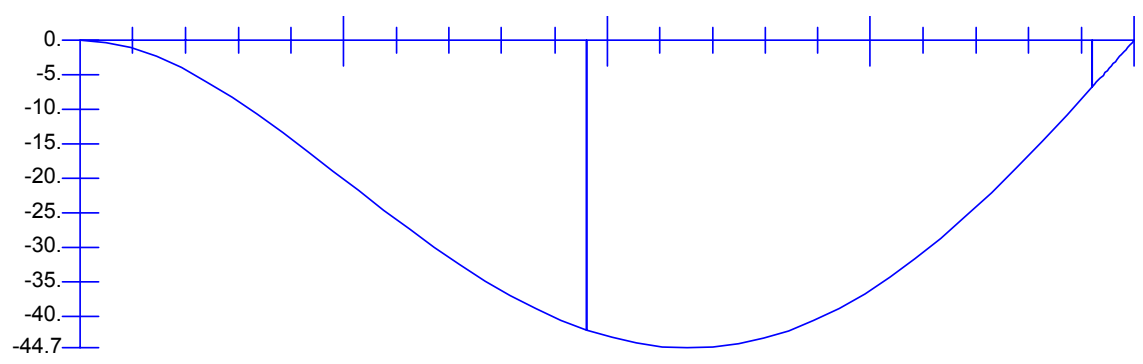

Figura 3.39 - Deslocamento horizontal (cm). 
- $\quad$ Verificação do cisalhamento:

Máxima cortante $-\mathrm{V}_{\max }=31,5 \mathrm{kN}$

$$
\left\{\begin{array}{c}
\tau_{d}=\frac{31,5 \cdot 1,4}{7,07 \cdot 10^{-2}}=0,623 \mathrm{MPa} \\
\tau_{u}=0,85 \cdot 2 \cdot \sqrt{0,007 \cdot 20}=0,636 \mathrm{MPa}
\end{array}\right\} \therefore \tau_{d}<\tau_{u}
$$

Levando-se em conta os cálculos segundo as equações 8 e 9, a tensão cisalhante atuante na seção está um pouco abaixo do limite de sua capacidade.

- $\quad$ Cálculo da armadura longitudinal:

Máximo momento fletor $-\mathrm{M}_{\max }=85 \mathrm{kN} . \mathrm{m}$

Força normal de compressão na estaca $-\mathrm{N}=266 \mathrm{kN}$

$$
\left.\begin{array}{c}
v=\frac{1,4 \cdot 266}{0,0707 \cdot \frac{20 \cdot 10^{3}}{1,6}}=0,42 \\
\mu=\frac{1,4 \cdot 85}{0,0707 \cdot 0,3 \cdot \frac{20 \cdot 10^{3}}{1,6}}=0,45
\end{array}\right\} \Rightarrow \omega \cong 2,1
$$

Para o caso analisado, $43 \mathrm{~cm}^{2}$ é a área da armadura longitudinal necessária para resistir o esforço de flexão atuante na estaca. 


\subsection{ANÁLISE DOS RESULTADOS}

O método de avaliação da pressão horizontal, proposto por Beer e Wallays, mostrou-se mais rigoroso para o caso estudado. Isso porque a determinação do valor, segundo este método, considera o posicionamento da estaca no interior do aterro.

Foi concluído que quando a estaca está sujeita a ações horizontais, provenientes do empuxo do solo, o projetista de fundações deve considerar tal carregamento no dimensionamento, caso contrário ele estará atuando contra a segurança da estrutura.

Constatou-se também que para suportar o esforço de flexão, a estaca necessitaria ser armada com uma grande quantidade de aço, o que, muito provavelmente, não deve ter ocorrido na prática. 


\section{CAPÍtULO 4}

\section{PROJETO DA RECUPERAÇÃO ESTRUTURAL}

\subsection{OBJETIVO DO CAPÍTULO}

O presente capítulo tem a finalidade de apresentar as medidas emergenciais adotadas e o projeto da recuperação estrutural do condomínio, proposto pelo escritório "Maffei Engenharia”. Cabe ressaltar, neste momento, que não está contemplado nesse trabalho o detalhamento e o acompanhamento das obras de reabilitação. Tal ausência de informação é justificada devido a imprevistos ocorridos na obra, que inviabilizaram a sua concretização. O item 4.4 faz menção aos problemas verificados.

\subsection{ETAPAS PRELIMINARES}

Após a ocorrência do sinistro, algumas medidas foram rapidamente tomadas, devido à urgência do caso. Dentre elas, destaca-se: a interdição da área afetada e das proximidades do condomínio, estabilização dos dois blocos de edifícios e a instrumentação necessária para medir os deslocamentos nas estruturas.

\subsubsection{PROCEDIMENTOS ADOTADOS LOGO APÓS O COLAPSO}

Imediatamente após o acidente ter ocorrido, uma comissão formada pelos condôminos foi organizada para analisar o caso e estudar a melhor solução a ser adotada. Com a posse do laudo técnico, o grupo optou por não demolir o prédio, e sim realizar sua recuperação estrutural.

O escritório "Maffei Engenharia" foi contratado para realizar a tarefa de reerguer toda a estrutura desabada e recondicioná-la adequadamente para o uso dos proprietários. 
Num primeiro momento, por motivo de segurança, a Defesa Civil interditou a área próxima do terreno e o acesso do público também ficou restrito apenas a pessoas autorizadas.

\subsubsection{ESTABILIZAÇÃO DOS EDIFÍCIOS}

Com a intervenção técnica no local, realizada pelo escritório Maffei Engenharia (MAFFEI, 2001), constatou-se que os dois blocos do condomínio necessitavam de rápidas medidas para eliminar a hipótese de novos desabamentos. Apesar do bloco "A" ter saído ileso do acidente ocorrido com o bloco vizinho, observou-se na perícia que seus pilares térreos deveriam passar por urgentes obras de reforço, visto que alguns deles apresentavam fissuras e desaprumo da ordem de $6 \mathrm{~cm}$. Evidenciou-se, na instrumentação realizada posteriormente ao acidente, que o bloco "B," mesmo depois de desabado, desenvolvia recalques constantes de sua estrutura, o que conferiu urgência em sua estabilização.

\section{a. Bloco "A"}

$\mathrm{Na}$ observação do edifício durante a perícia, notou-se que ele apresentava deficiências estruturais referentes à concepção de projeto e na maneira como ele foi executado. Concluiu-se que o edifício estava insuficientemente rígido nas extremidades, na direção perpendicular às suas maiores faces, devido à baixa inércia dos pilares do térreo nessa direção (ver figura 4.1).

Observou-se que alguns pilares do bloco "A", após o colapso ocorrido no bloco "B”, estavam prestes a ruir (figura 4.2). A equipe técnica, então, pensou que a medida mais segura a ser tomada seria o escoramento dos elementos danificados.

Nos dias subseqüentes, um dos pilares que se encontravam defeituosos ruiu (figura 4.3), transferindo às escoras todo o carregamento do edifício. Essas escoras suportaram o peso do prédio durante o período de oito horas e, após este tempo, como mostra a figura 4.4, foi feito um escoramento mais resistente para garantir a sustentação, até que três pilares definitivos de concreto armado fossem executados, no lugar do pilar ruído (figura 4.5). 


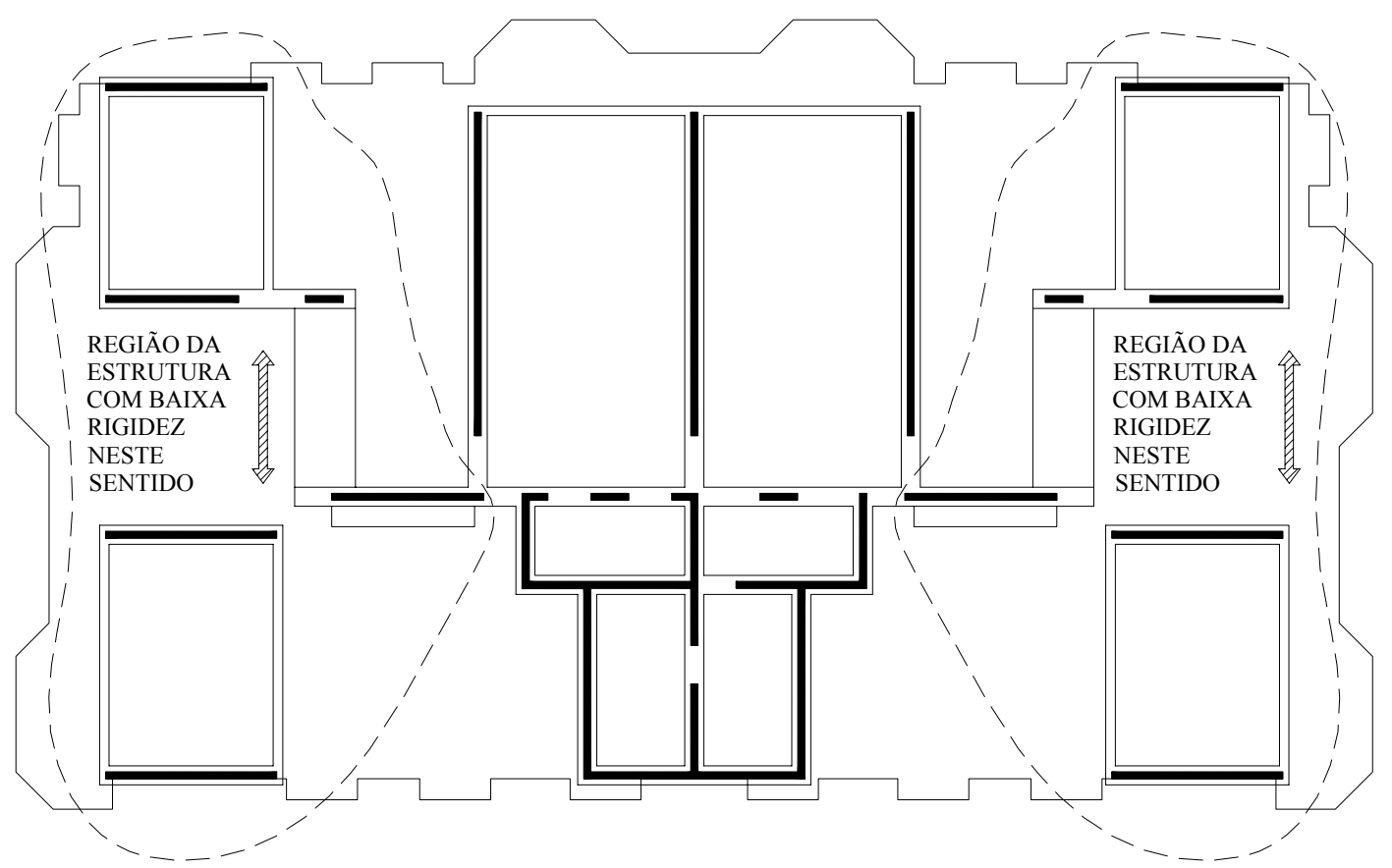

Figura 4.1 - Pequena rigidez do térreo na direção perpendicular às maiores faces do edifício.

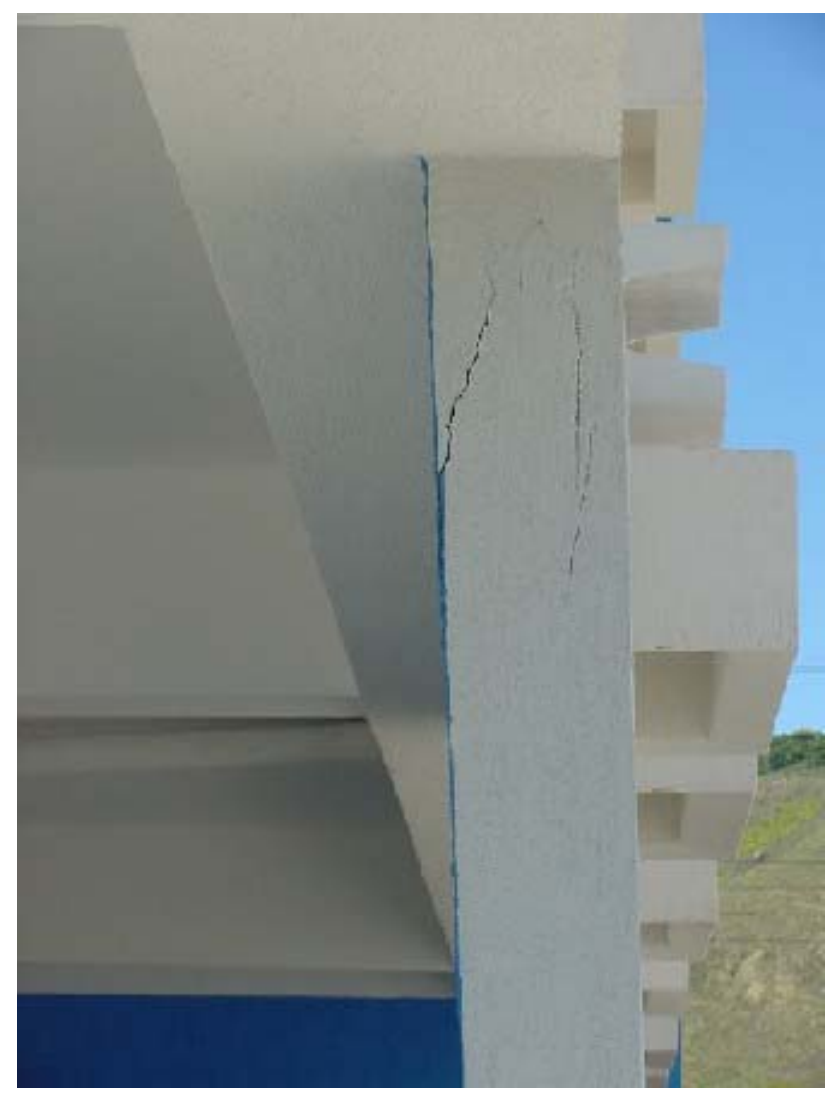

Figura 4.2 - Pilar com desaprumo e fissuras em sua parte superior - Maffei Engenharia. 


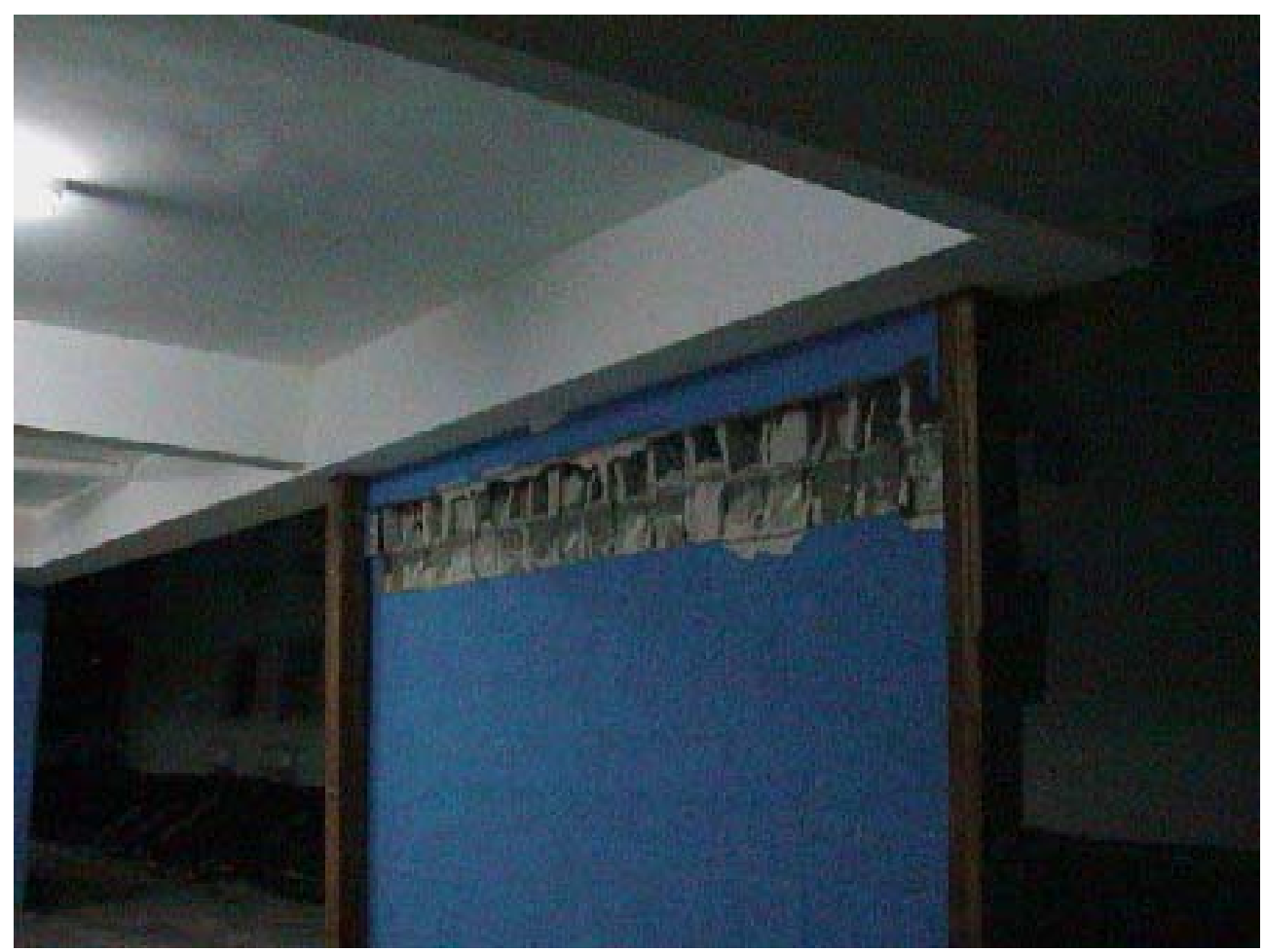

Figura 4.3 - Pilar ruido - Maffei Engenharia.

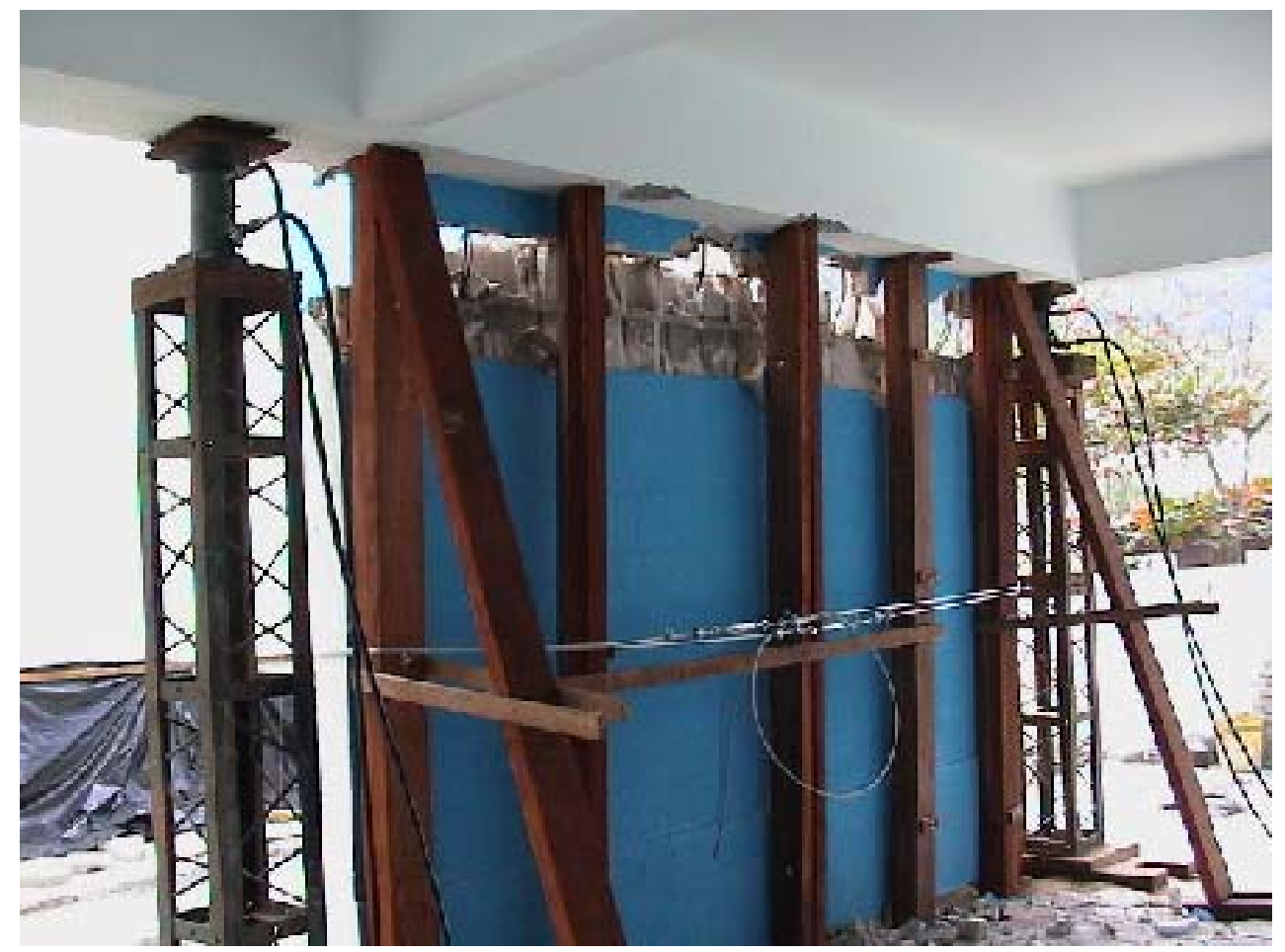

Figura 4.4 - Escoramento utilizado na sustentação do edifício- Maffei Engenharia. 


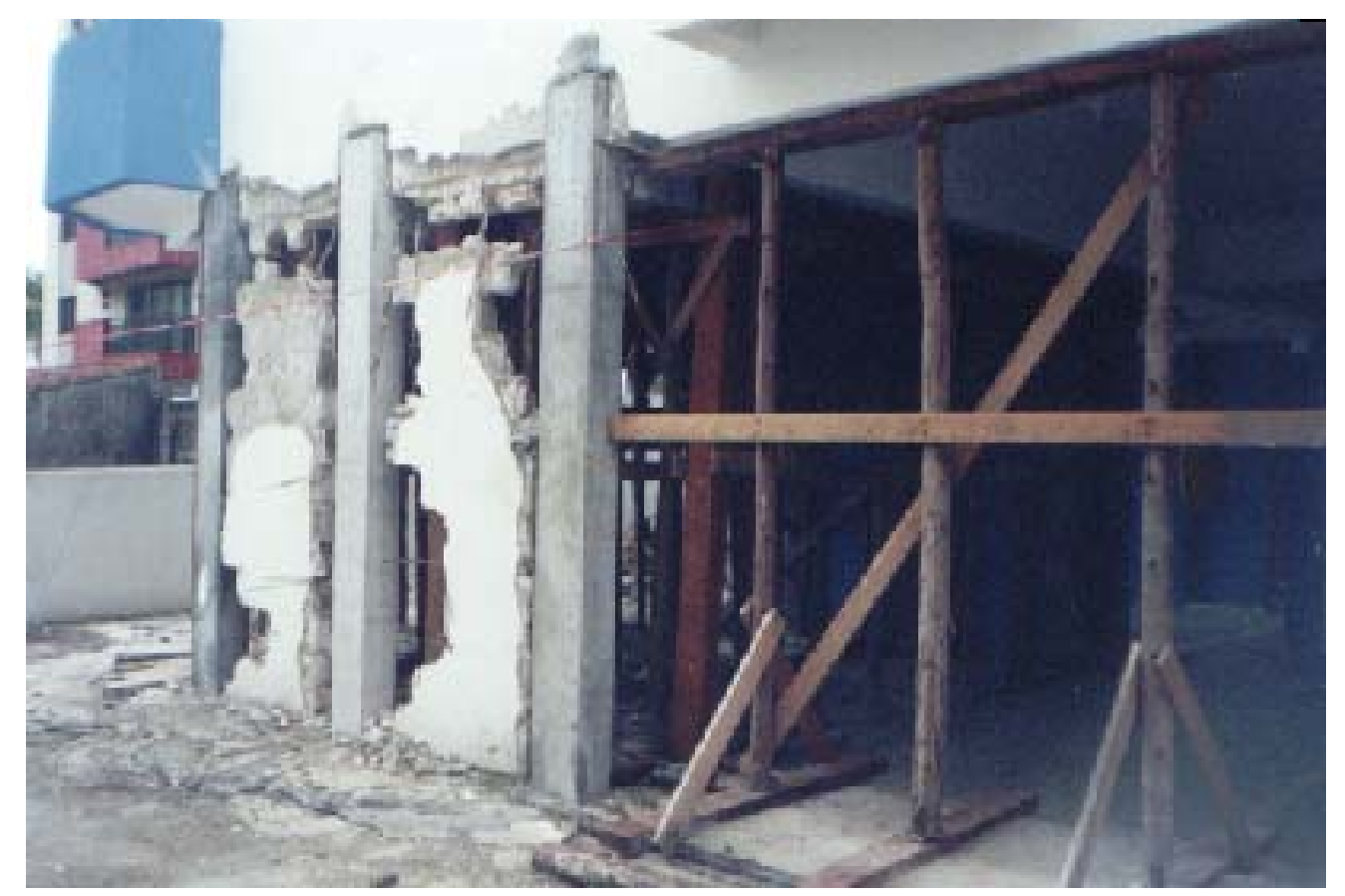

Figura 4.5 - Reforço com três colunas de concreto armado- Maffei Engenharia.

Nota-se pela figura 4.3, que se não fosse tomada a medida preventiva de escorar a coluna danificada, inevitavelmente o bloco "A" do condomínio sofreria um sinistro mais grave.

Depois que o pilar rompeu, observou-se que ele não estava convenientemente estruturado com armadura e graute. A figura 4.6 exibe o detalhe da parte superior desse pilar após o colapso; vê-se que a taxa de armadura e a quantidade de graute naquela região são mínimas, confirmando a pequena capacidade de suporte do pilar.

Fundando-se no receio da probabilidade de todos os pilares não estarem armados e com a intenção de aumentar a rigidez da estrutura de transição do edifício, a equipe optou por reforçar toda a estrutura do térreo, construindo pórticos de concreto armado que substituíram os antigos pilares.

Nota-se na figura 4.7 que os pórticos de reforço foram orientados na direção da menor inércia dos antigos pilares do térreo, justamente para enrijecer a estrutura nessa direção. 


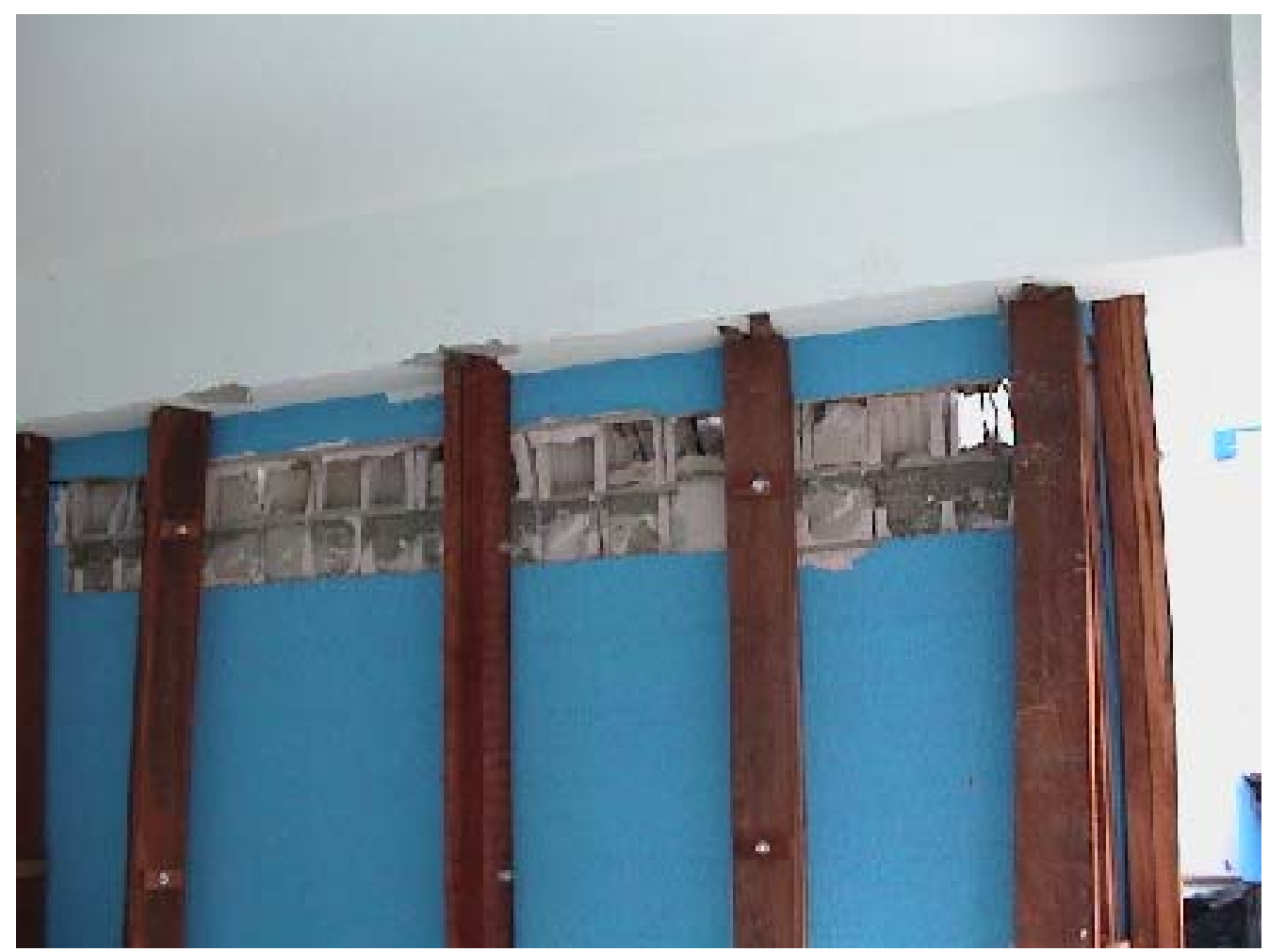

Figura 4.6 - Ausência de armaduras e grautes- Maffei Engenharia.

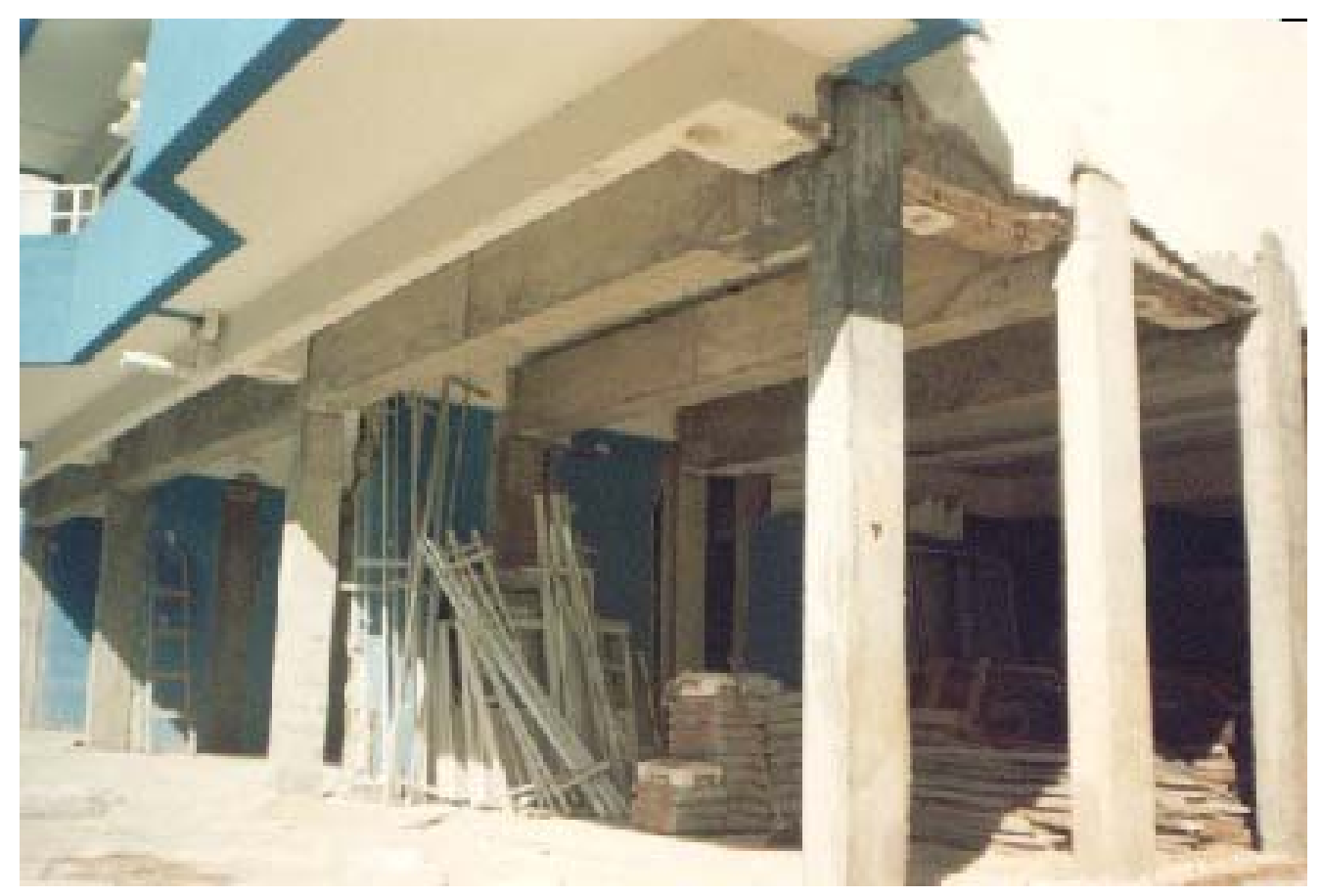

Figura 4.7 - Estrutura de reforço. 


\section{b. Bloco "B"}

Como foi detalhado no capítulo 3, evidenciou-se que a causa do acidente foi um escorregamento do solo localizado sob o aterro, o qual estava confinado pelos muros de divisa do condomínio. Esse escorregamento teve como origem a diferença de pressão exercida no solo pelo aterro, devido à diferença de nível entre os lados de dentro e de fora do terreno.

Num primeiro momento julgou-se importante acrescentar, abaixo do edifício desabado, junto ao solo, uma massa líquida de concreto para preencher os espaços vazios (figura 4.8). Esse material seria responsável pela condução e distribuição do peso ao longo de toda superfície de contato; dessa forma os deslocamentos seriam reduzidos, uma vez que o carregamento atuante seria amenizado pelo fato de estar melhor distribuído.

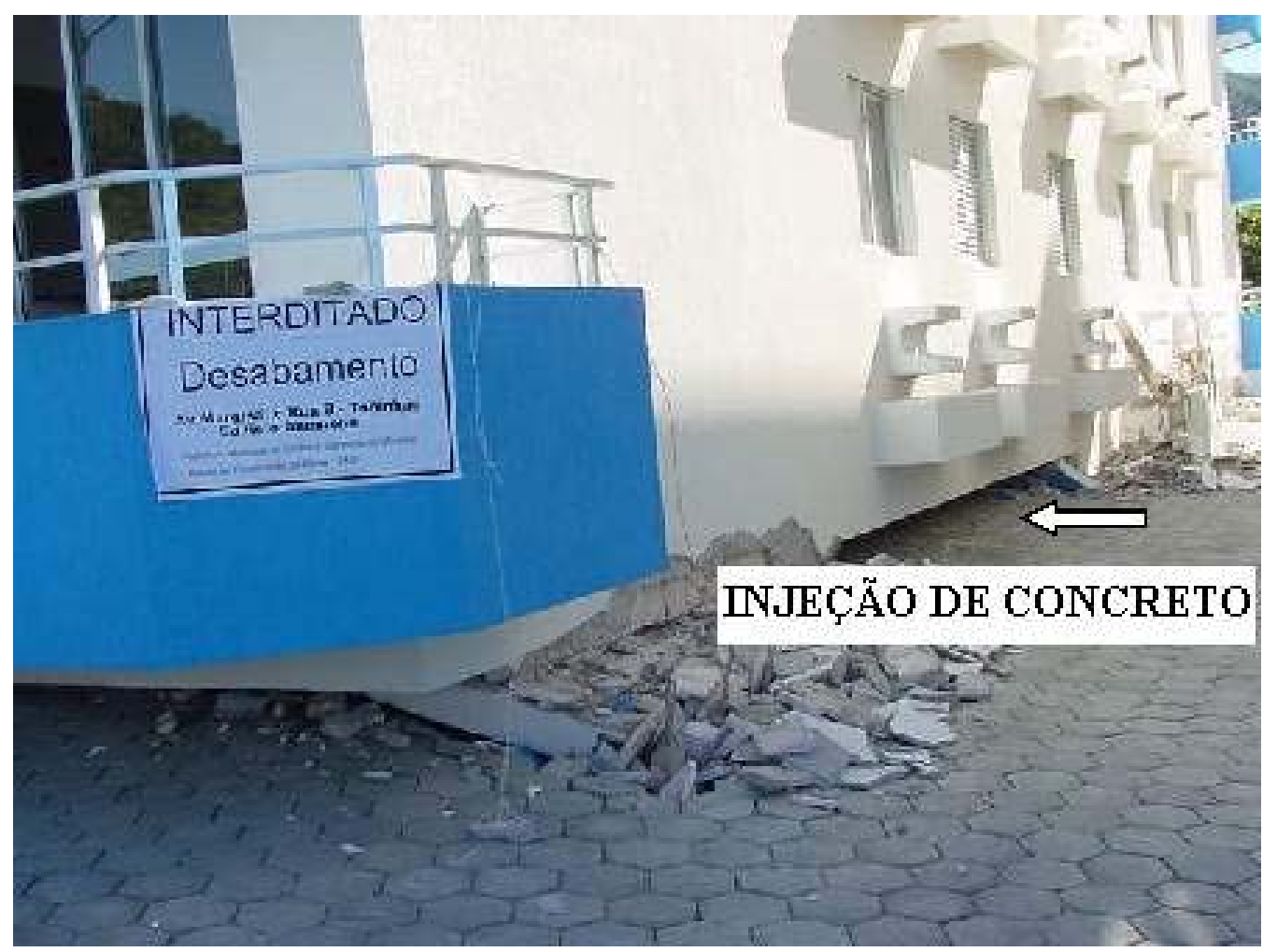

Figura 4.8 - Hipótese de injeção de concreto para estabilização - Maffei Engenharia. 
Seria uma solução simples, no entanto percebeu-se que não deveria ser colocada em prática. $\mathrm{O}$ acréscimo desse material, no intuito de proporcionar estabilidade à estrutura, poderia criar sérios efeitos colaterais no processo de recuperação. $\mathrm{O}$ volume de concreto aumentaria a solicitação no solo colapsado, o que poderia agravar o problema de escorregamento do aterro. Outro fato que sucederia seria uma possível pressão excessiva sobre a laje em contato, o que poderia causar sua ruptura e, por fim, a reconstrução do térreo ficaria dificultada, devido ao impecilho que seria essa grande massa endurecida.

Uma das medidas tomadas para estabilizar a estrutura, como mostra a figura 4.9, foi compactar volumes de solo adjacentes à divisa, pelo lado de fora: com esse acréscimo de peso, conseguiu-se equilibrar a diferença de pressão exercida na fundação.

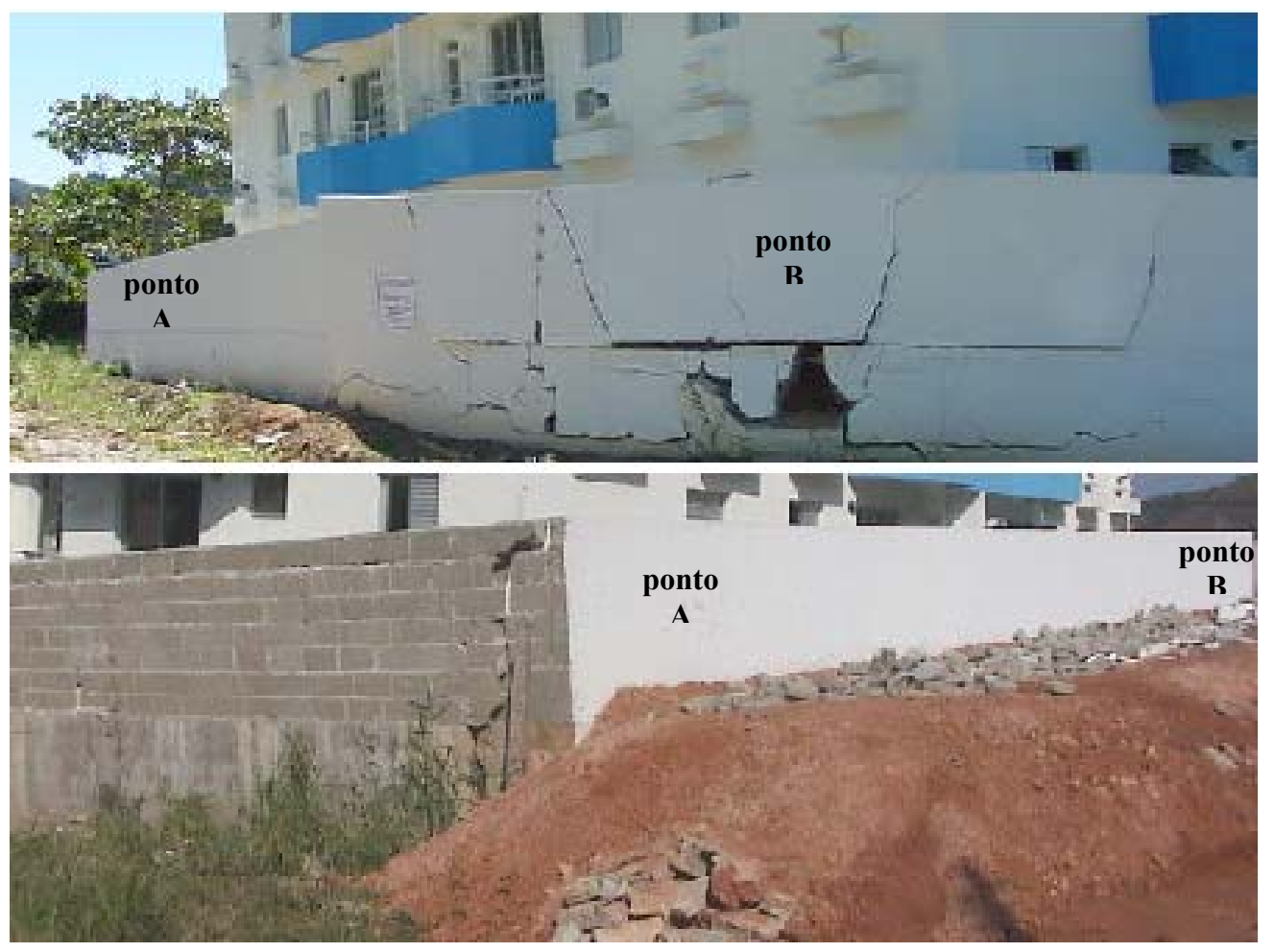

Figura 4.9 - Antes e depois do acréscimo de solo junto à divisa do terreno- Maffei Engenharia.

Como se pode observar na figura 4.10, outra medida adotada com o objetivo de reduzir o deslocamento foi evitar infiltração da água de chuva na fundação. Para tanto, o pavimento térreo, próximo do bloco "B", foi inteiro 
impermeabilizado com argamassa especial própria para esse tipo de tarefa, e também foram dispostas lonas plásticas sobre o piso, com o objetivo de desviar o curso da água para fora do local afetado.

Ficou constatado que o reservatório de água inferior localizava-se enterrado abaixo do nível do térreo, entre os dois edifícios do condomínio. Considerou-se necessário esvaziá-lo com o mesmo propósito, ou seja, o de evitar possíveis infiltrações de água nas fundações danificadas.

Como o piso do local é composto por blocos sextavados de concreto, os espaços vazios existentes entre eles foram todos preenchidos com material impermeável. A seqüência desse serviço está apresentada na figura 4.10.
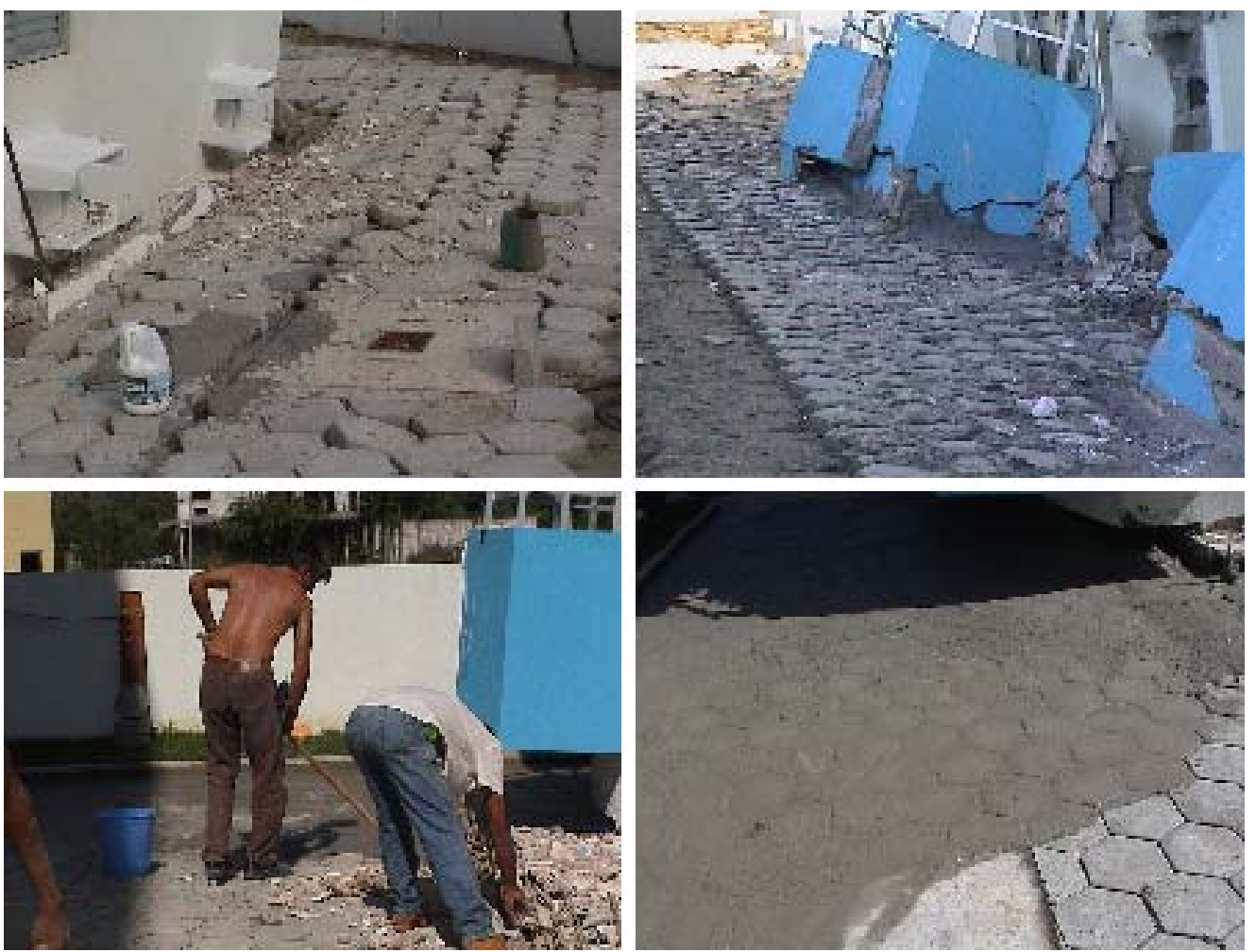

Figura 4.10 - Impermeabilização do piso com argamassa aditivada- Maffei Engenharia.

Logo nas primeiras intervenções técnicas no local, foram construídas, ao redor do edifício desabado, 44 estacas escavadas e preenchidas com injeção de calda de cimento sob pressão. Esses elementos (que serão descritos com mais riqueza de detalhes no item 4.3.1) formariam o sistema de sustentação da estrutura metálica 
provisória, responsável pela elevação do edifício. Cabe ressaltar, todavia, que o tipo de tecnologia construtiva, empregada nessas estacas, contribuiu para reduzir significativamente as taxas de recalque da estrutura, medidas ao longo dos primeiros dias.

Esse abrandamento nos deslocamentos foi creditado a uma pequena capacidade de contenção que tais elementos de fundação proporcionaram ao solo colapsado.

Apesar do desabamento ocorrido ter causado preocupação aos proprietários das edificações vizinhas, é muito pequena a probabilidade de que futuramente a estrutura venha a tombar e causar algum dano extra. Isso devido à geometria do prédio ser favorável à segurança: baixo e com base larga e, por isso, a resultante dos esforços verticais tem de se afastar bastante do centro de gravidade do edifício, para que ele tombe.

Outro fator que diminui a possibilidade de o edifício tombar é a não ocorrência de ventos fortes, capazes de derrubá-lo.

\subsubsection{INSTRUMENTAÇÃO}

No início das vistorias após o acidente, verificou-se a necessidade de se instrumentar o edifício, medir a estabilidade do conjunto desabado e também avaliar a possibilidade de novas ocorrências de deslocamentos e de inclinações. Para realizar esse trabalho, foi contratada uma empresa especializada em instrumentação, que efetuou medições com teodolito duas vezes ao dia.

A empresa instrumentou o edifício apenas nos dez primeiros dias de sua contratação, devido ao alto custo da operação. Nos dias subseqüentes, os próprios engenheiros da obra realizaram a tarefa, observando o nível da água em mangueiras transparentes, dispostas nas quatro extremidades do prédio. Apesar das medidas realizadas com mangueiras terem precisão inferior aos valores encontrados com o teodolito, elas atenderam satisfatoriamente às expectativas dos engenheiros, fornecendo uma precisão da ordem de $0,5 \mathrm{~cm}$. 
As quatro extremidades instrumentadas do edifício foram numeradas de acordo com a figura 4.11, e os recalques medidos nos respectivos pontos estão representados no gráfico da figura 4.12 .

Nota-se pelo gráfico da figura 4.12 que a estrutura do bloco "B" continuou apresentando expressivos recalques e aumento de inclinação, mesmo após as intervenções de estabilização.

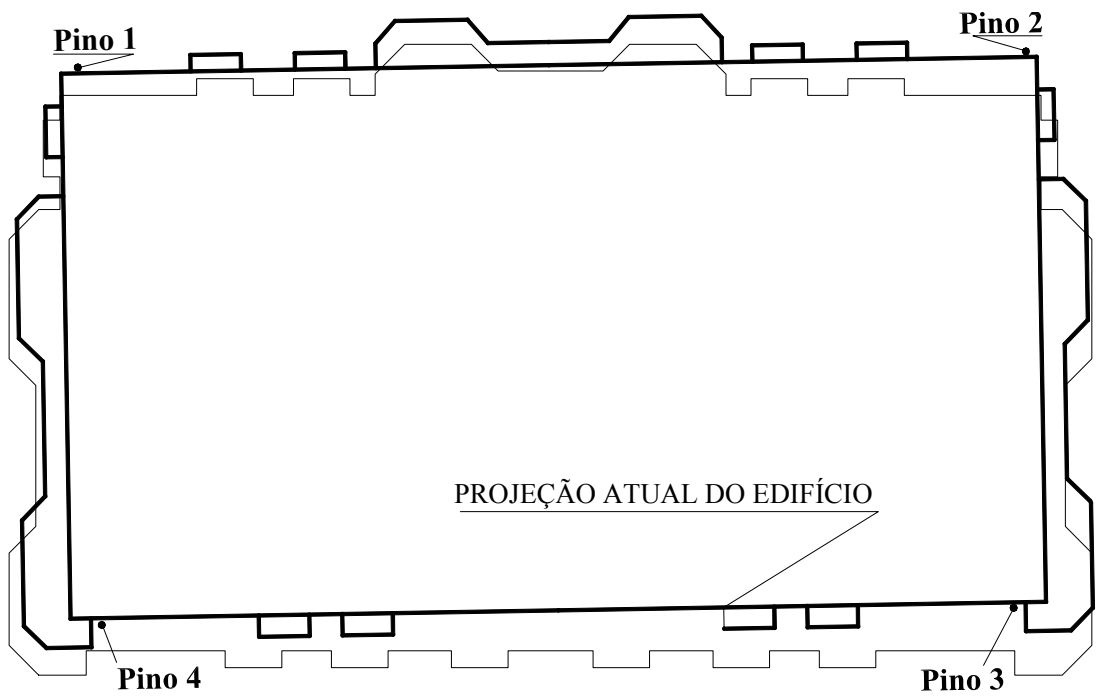

Figura 4.11 - Pontos instrumentados.

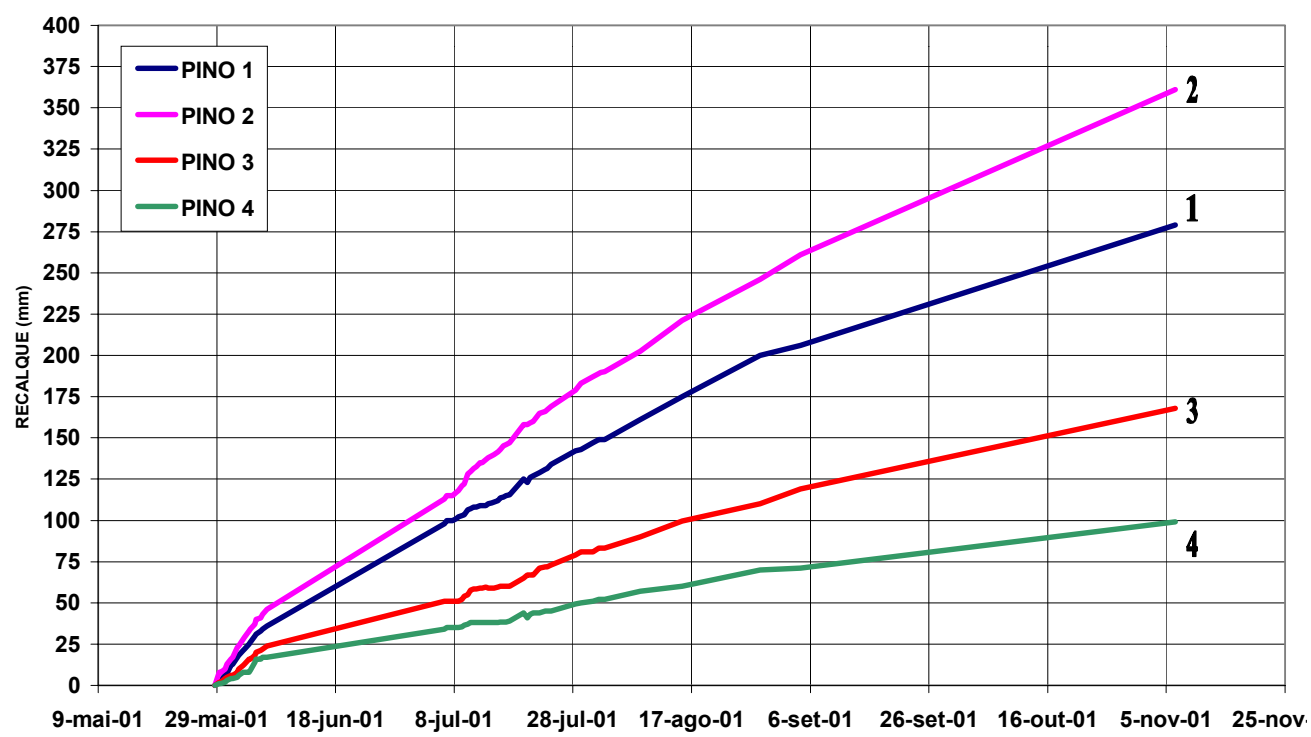

Figura 4.12 - Recalque durante os sete primeiros meses Maffei Engenharia. 
A progressão da inclinação da estrutura foi monitorada com auxílio de dois pêndulos. Eles foram fixados no parapeito do último pavimento, sendo um em cada extremidade do edifício. A figura 4.13 mostra um desses pêndulos suspenso no ar e afastado aproximadamente $2,5 \mathrm{~m}$ da base do edifício.

Uma medida eficiente foi posicionar pequenos pedaços de vidro sob o bloco desabado, como mostra a figura 4.14. Assim, um pequeno deslocamento da estrutura faria com que os vidros se rompessem e evidenciassem a movimentação.

Outro controle importante, realizado durante os dias em que se manipulou a instrumentação, foi a verificação da formação e da progressão das fissuras ocorridas nas paredes restantes do bloco "B".

Para realizar tal tarefa, aplicou-se sobre as paredes uma fina camada de massa corrida, de maneira que, com um pequeno aumento da abertura da fissura, a massa aplicada romper-se-ia e indicaria o acréscimo dessa abertura. A figura 4.15 mostra esse procedimento sendo feito no muro de divisa do terreno.

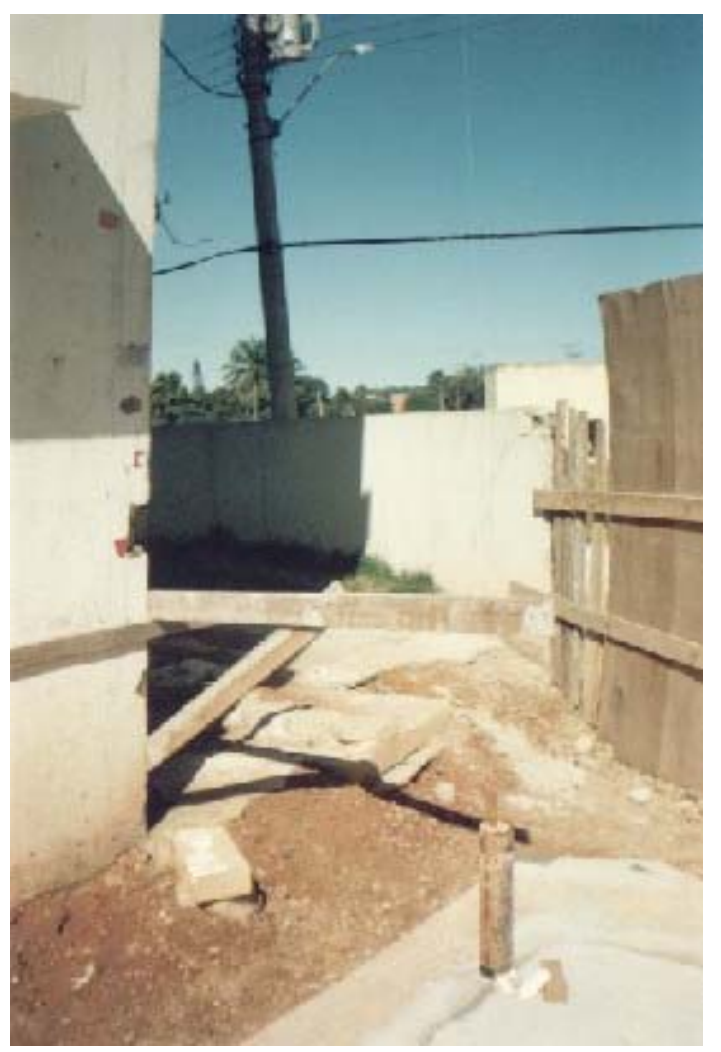

Figura 4.13 - Pêndulo utilizado para medir a inclinação do edificio. 


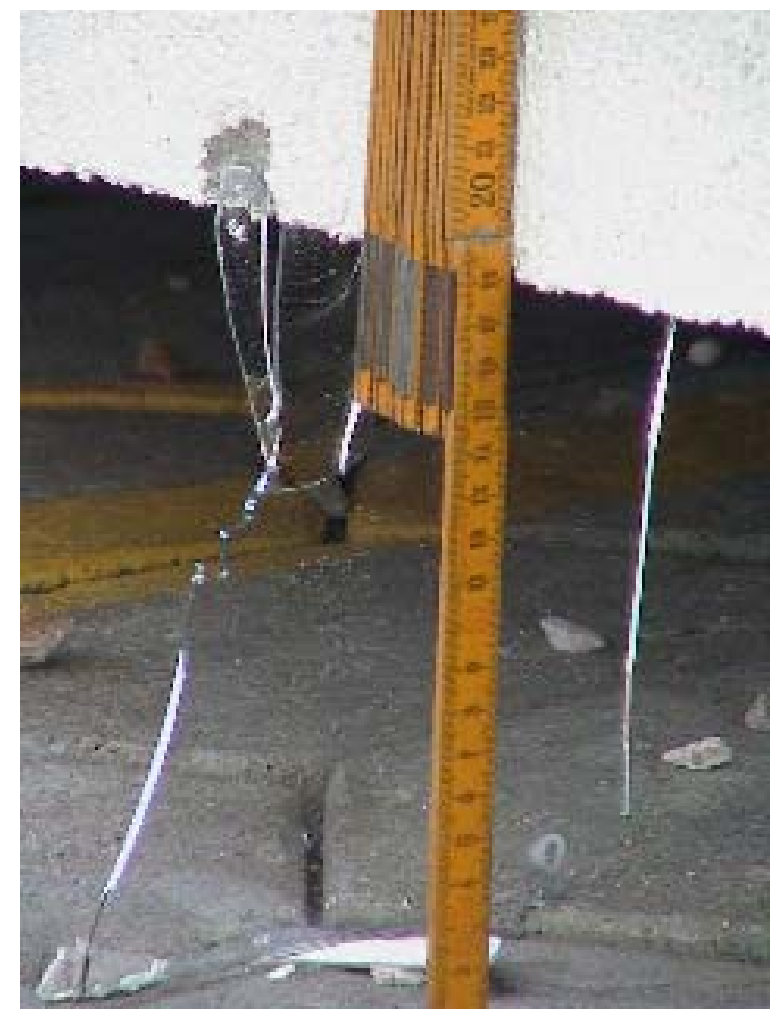

Figura 4.14 - Vidro detectar pequenos deslocamentos- Maffei Engenharia.

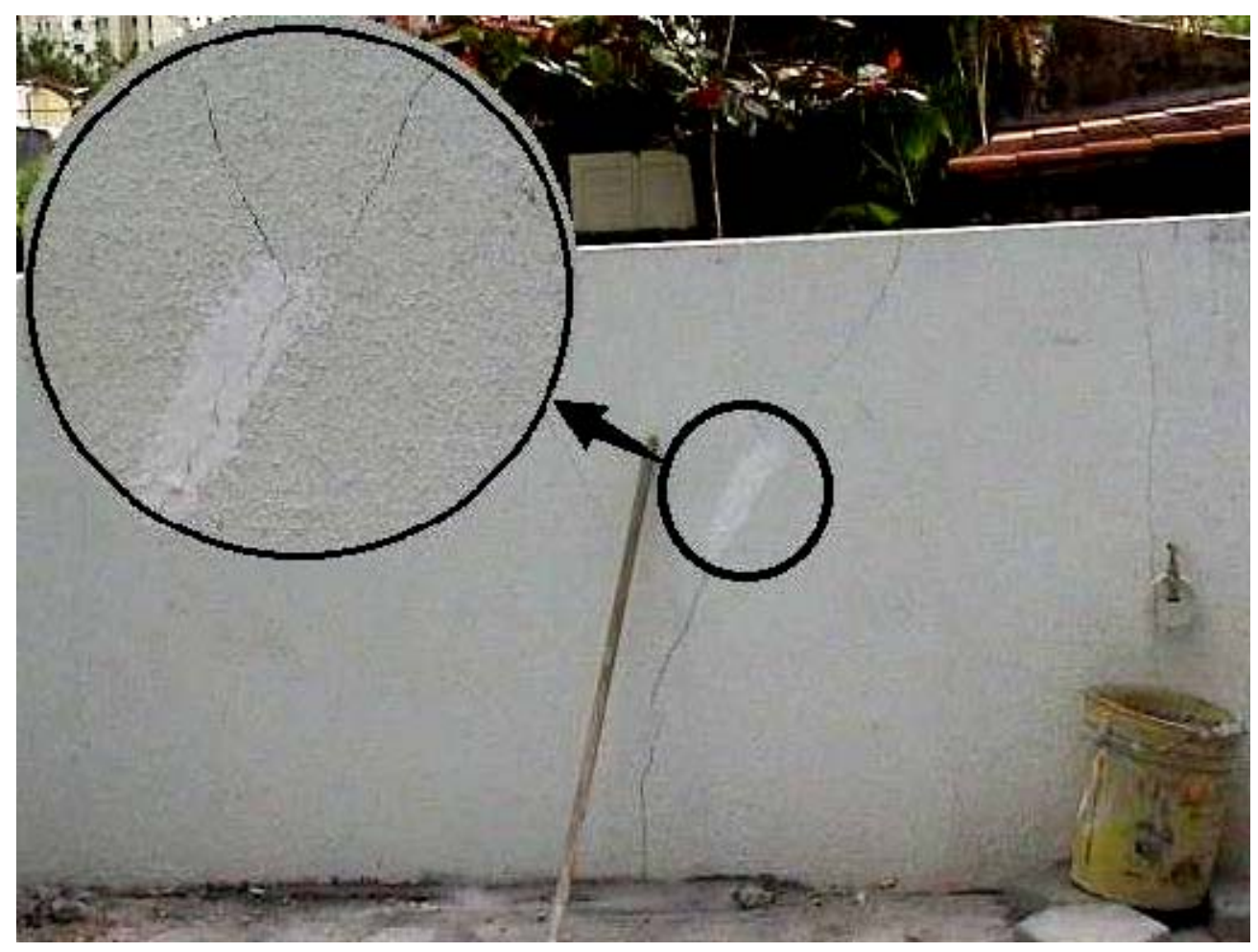

Figura 4.15 - Massa corrida sobre fissura para controle da sua abertura- Maffei Engenharia. 


\subsection{PROCESSO DE RECUPERAÇÃO}

Será apresentada neste item, a proposta de recuperação estrutural elaborada pelo escritório "Maffei Engenharia”. O projeto prevê que para recuperar o bloco "B" será necessário reerguê-lo o equivalente à altura de um pé direito. Essa tarefa será exeqüível graças ao auxílio de uma estrutura metálica provisória, que será disposta rente às faces externas do conjunto.

Ao término da estrutura auxiliar ser montada e devidamente fixada no edifício, um sistema de macacos hidráulicos será posicionado de modo a propiciar, quando forem acionados, a elevação de todo o bloco "B". À medida que o edifício for sendo erguido, serão ajustadas várias escoras sob ele, com o objetivo de garantir a segurança nos casos de uma possível falha no sistema de elevação.

A etapa seguinte à da elevação do edifício será a de reconstrução do pavimento térreo. Para a concretização de tal meta, será preciso construir novas fundações, bem como estruturar vigas e pilares de concreto armado, moldados "in loco”. Logo após toda a reconstrução, a estrutura metálica será desmontada e o processo de recuperação estrutural estará encerrado.

Nos itens que se seguem será descrito mais pormenorizadamente todo o processo detalhado no projeto.

\subsubsection{SISTEMA PROVISÓRIO DE FUNDAÇÕES}

Como foi comentado, a elevação do edifício será feita por meio de uma estrutura metálica auxiliar, que por sua vez terá de descarregar no solo todas as ações provenientes do suporte do prédio. Para tanto, foi executado, paralelamente aos dois lados maiores do edifício, um conjunto de estacas adequadamente dimensionadas para suportar os esforços solicitantes durante essa operação (figura 4.16).

Cada pilar metálico descarregará as ações em um conjunto de três estacas, exceto os dois pilares situados no eixo central, que por serem mais solicitados, possuirão um suporte de reação formado por quatro estacas. As ações serão encaminhadas às fundações via blocos de transição, construídos nas cabeças das estacas, totalizando sete elementos de fundação, de cada lado maior do edifício. 
As dimensões desses blocos de transição foram projetadas com o propósito de alojar, sobre eles, os macacos hidráulicos, que farão o içamento da estrutura, e duas colunas de concreto ou aço, que farão o escoramento do edifício.

Observa-se na figura 4.16 que algumas estacas foram inutilizadas por falha de execução. No lugar delas foram construídas outras estacas, alterando, assim, a geometria de alguns blocos de transição.

Como o solo do local foi a causa do sinistro ocorrido e sempre exigiu cuidados especiais, preferiu-se evitar ao máximo a utilização de água no processo de execução dessas estacas. O receio era de que, com a inclusão da água nas escavações das fundações, ela poderia reduzir a capacidade de suporte do solo, agravando ainda mais o problema de escorregamento do material.

Para executar as estacas, efetuou-se um processo de escavação alternativo: ao invés de água foi injetada calda de cimento sob pressão. Além de resolver o problema comentado anteriormente, esse processo melhorou substancialmente as características físicas do solo no local colapsado.

Pelo fato do edifício estar inclinado e a distância ser pequena entre ele e o muro de arrimo da divisa do fundo do terreno, o local não pode abrigar a haste de perfuração do equipamento.

Para usar equipamentos de menor porte, a inclusão de água no sistema seria inevitável; optou-se, portanto, pela demolição das sacadas de um dos lados do edifício (figura 4.17). Assim, a haste, que antes não cabia, pôde ser adequadamente posicionada.

Antes de iniciar as escavações, foram feitas algumas sondagens em pontos estratégicos do terreno. Os resultados das amostras indicaram que a camada de solo impenetrável localizava-se a 35 metros do nível do terreno, mas, durante a perfuração das estacas, os operadores constataram que aos 25 metros o solo já se encontrava impenetrável. 


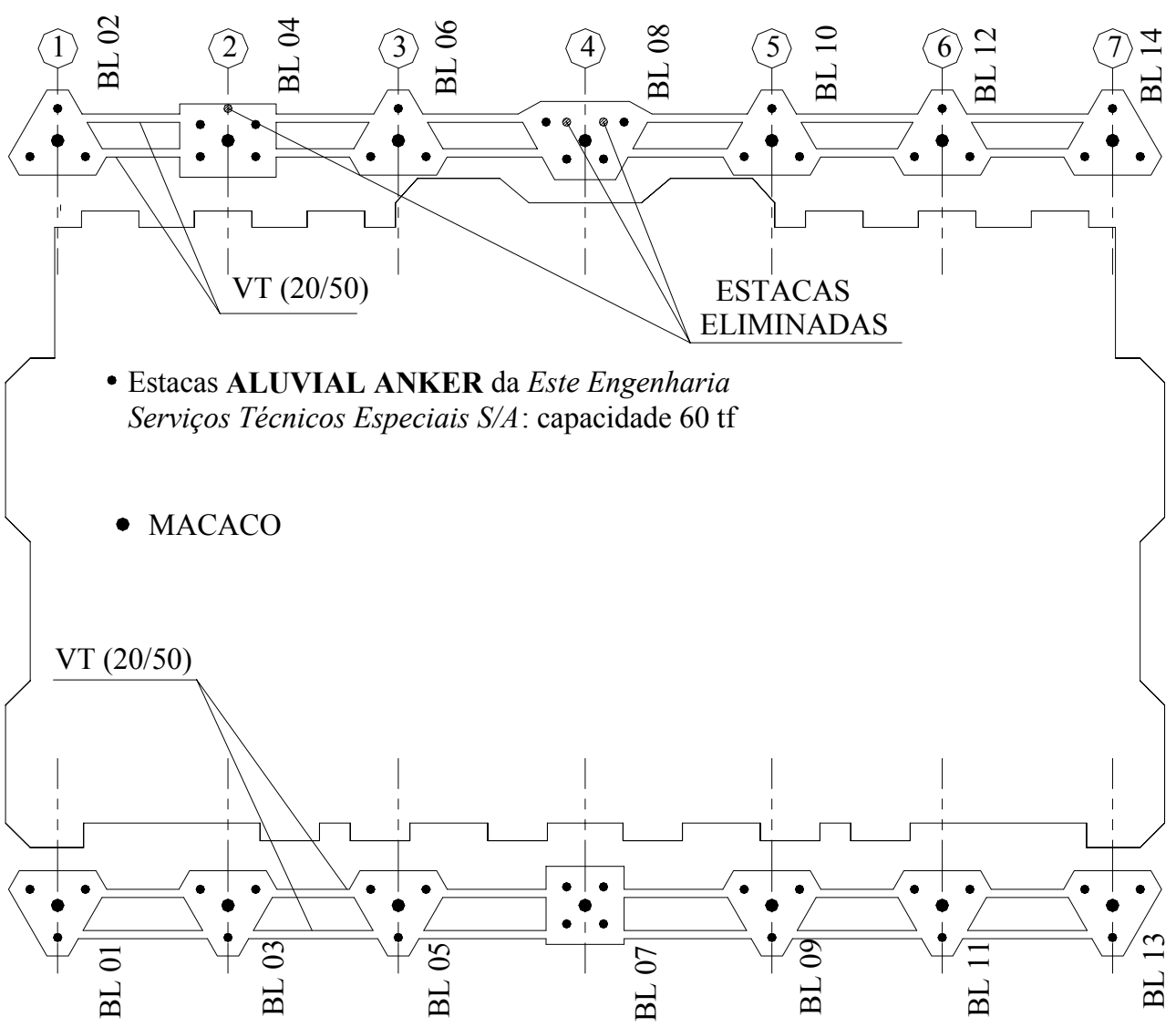

Figura 4.16 - Fundação provisória.

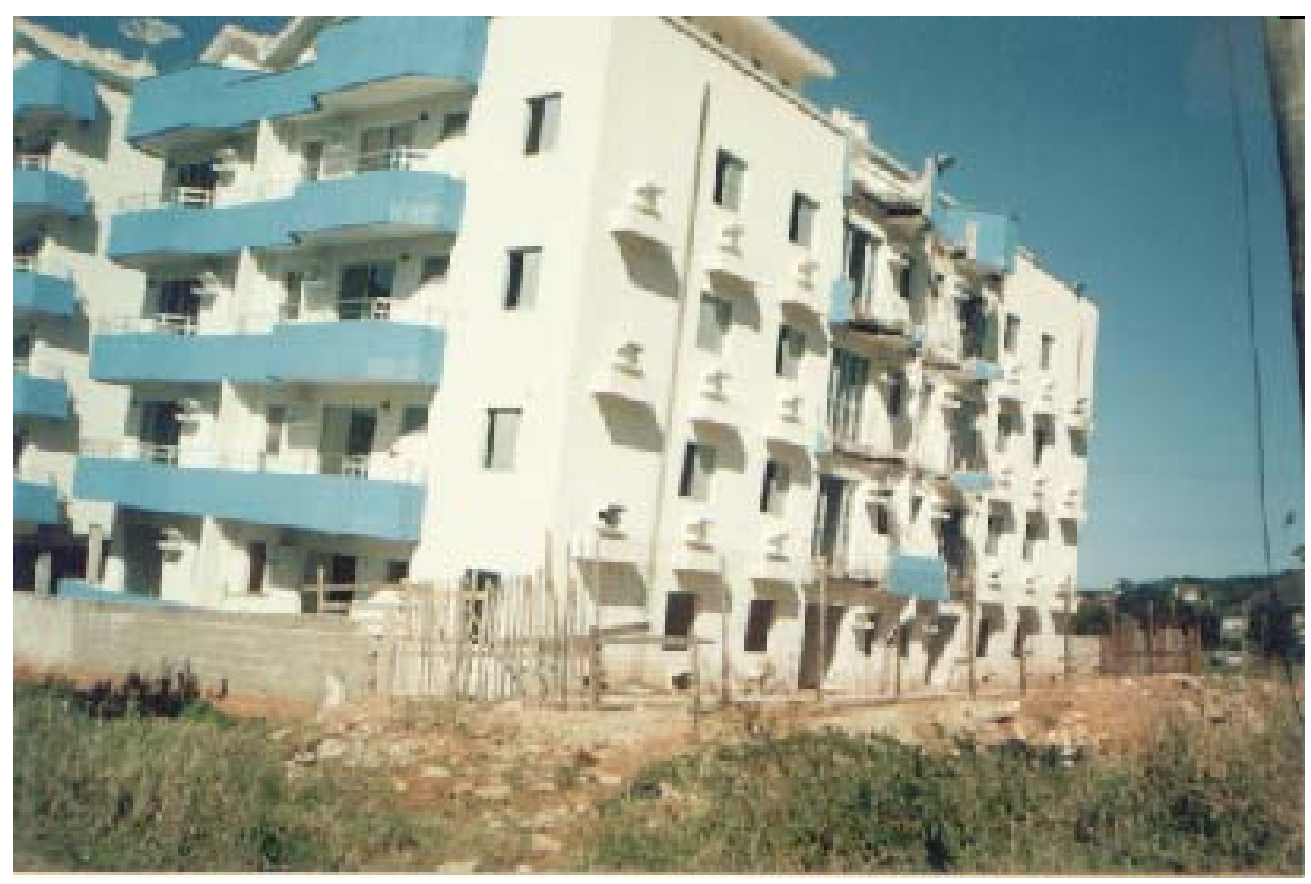

Figura 4.17 - Sacadas demolidas para permitir a execução de algumas estacas. 
Todos os blocos de transição foram interligados por duas linhas de vigas dispostas no nível do piso térreo. Elas foram construídas com o propósito de promover o travamento e absorver eventuais esforços provenientes de carregamentos excêntricos, aplicados pelos macacos hidráulicos sobre os blocos. Dessa maneira, os elementos de transição serão preservados de esforços não previstos no seu dimensionamento. A figura 4.18 mostra a fundação provisória concluída.

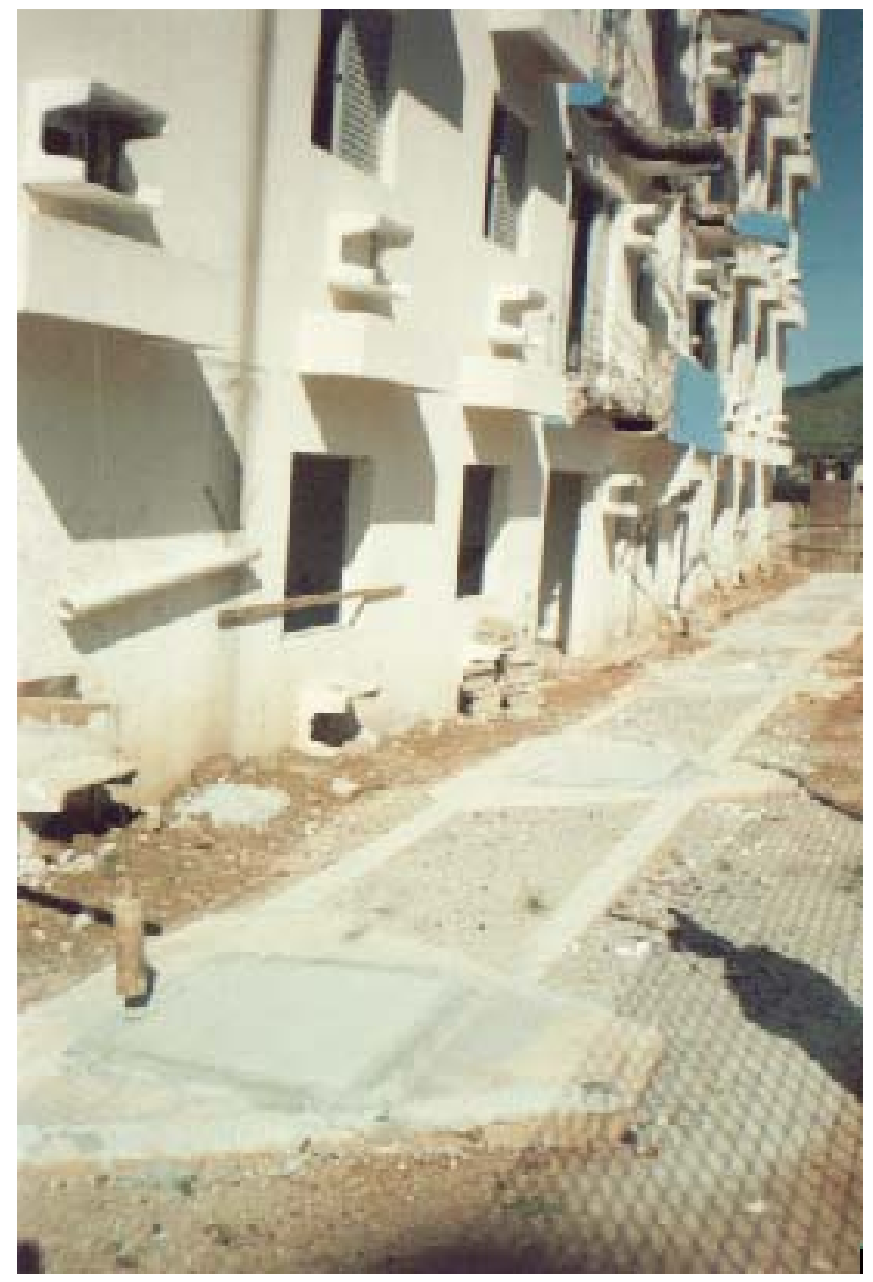

Figura 4.18 - Fundação provisória posicionada na parte externa do edificio. 


\subsubsection{PAREDES PROVISÓRIAS}

Uma recuperação estrutural do tipo que será realizada no bloco " $\mathrm{B}$ " não é uma obra simples de ser realizada; além de requerer um grande esforço técnico no sentido de elaborar um sistema capaz de executar a tarefa, inevitavelmente depende de um estudo mais detalhado da viabilidade econômica do sistema proposto.

Entende-se que a obra de recuperação pode ser feita de diversas maneiras. No entanto, é de extrema relevância que, dentre todos os anteprojetos, seja eleito aquele que possuir boa qualidade técnica aliada às possibilidades materiais de quem está executando.

Com a preocupação descrita anteriormente, a empresa "Maffei Engenharia", responsável pela reabilitação do edifício, planejou um sistema otimizado visando o mínimo gasto possível com a estrutura metálica auxiliar - item de maior contribuição no orçamento da obra.

Para tanto se projetou um conjunto de sete treliças planas, capazes de sustentar o edifício e possibilitar a elevação de todo o conjunto, utilizando-se macacos hidráulicos como força motriz. A treliça em questão, que será detalhada no item 4.3.3, foi otimizada devido à inclusão das paredes localizadas no primeiro pavimento, como elementos ativos do sistema de recuperação. Elas viabilizarão, durante a elevação, o trabalho conjunto de toda a estrutura metálica auxiliar, com as vigas de transição existentes no projeto original, atualmente apoiadas sobre o solo.

Como será visto posteriormente, o banzo inferior da treliça posicionar-se-á no teto do primeiro pavimento. Quando os macacos hidráulicos forem acionados, a treliça será suspensa, trazendo consigo as vigas de transição e, por conseguinte, todo o edifício. Para efetuar o transporte do peso do edifício das vigas de transição ao banzo inferior da treliça, serão utilizadas cantoneiras metálicas, fixadas rigidamente nos dois elementos.

Percebe-se que o encaminhamento natural das forças envolvidas, durante o processo de recuperação, dependerá do bom desempenho das alvenarias situadas no

primeiro pavimento. Para essas paredes viabilizarem com êxito a transmissão dos carregamentos em questão, serão vedadas todas suas aberturas - como portas, janelas e vãos - situadas nos eixos principais (figura 4.19). 


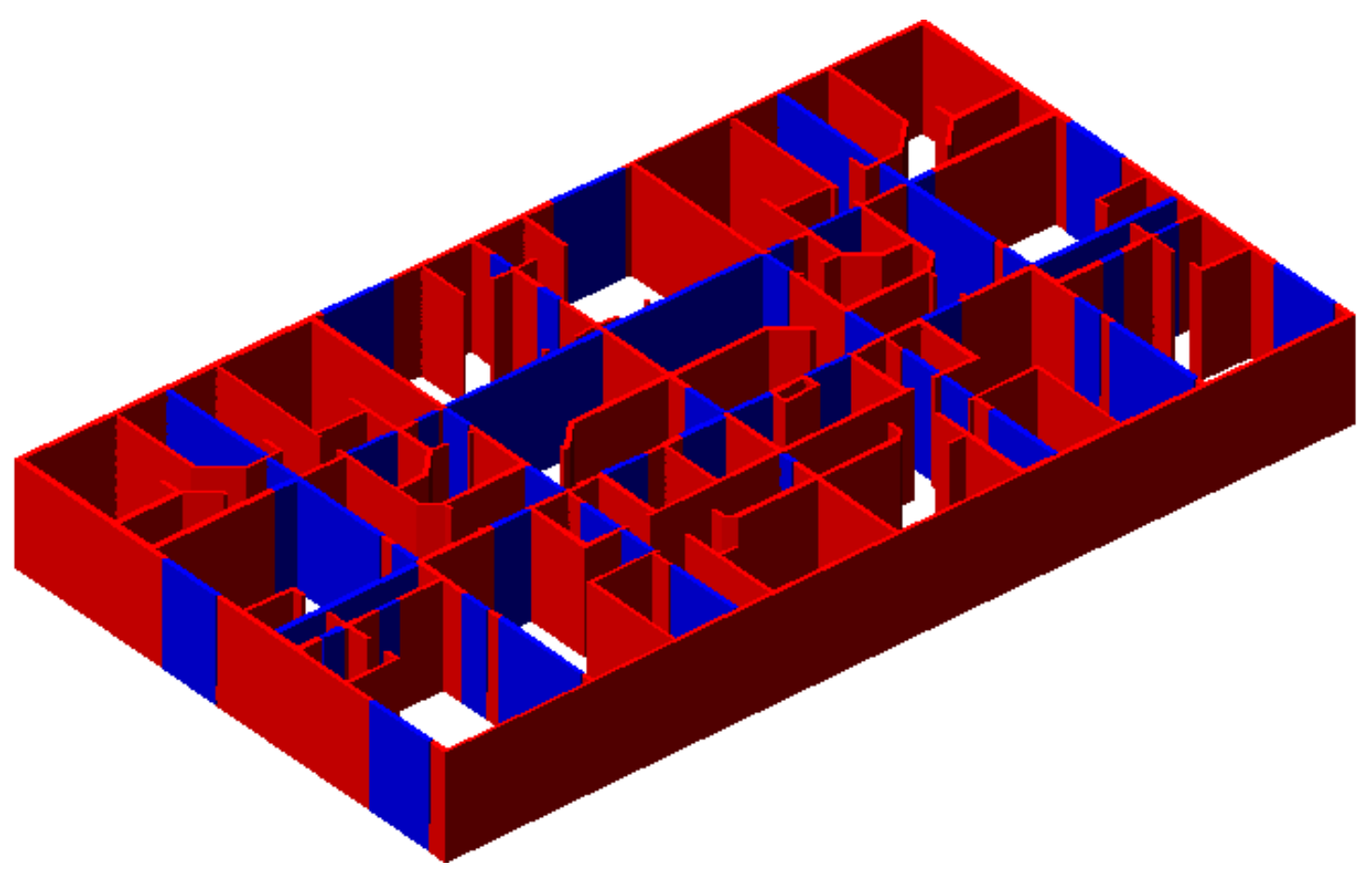

Figura 4.19 - Eixos reforçados com paredes provisórias representadas em azul.

Durante a ascensão do sistema, todas as vigas envolvidas na operação sofrerão esforços de flexão, fazendo com que surjam flechas nesses elementos. As paredes do primeiro pavimento, situadas sobre essas vigas, tenderão a trabalhar em conjunto e, justamente por essa razão, poderão apresentar fissuras. Para evitar tal fato, elas receberão um tratamento especial.

Os reforços serão feitos nas paredes situadas na direção dos eixos principais, os quais contêm os pórticos de elevação, e também em outras seis linhas de alvenaria, perpendiculares a esses eixos.

Para evitar a excessiva formação de fissuras nas paredes do primeiro pavimento, depois que as vigas sofrerem flexão, todos os eixos ora explicitados serão enrijecidos com a protensão de seis linhas de cabos de aço de alta resistência. Esses cabos serão dispostos em três níveis diferentes, ao longo da altura das paredes, nas suas duas faces (figuras 4.20, 4.21, 4.22). 
Força aplicada pelos cabos de aço

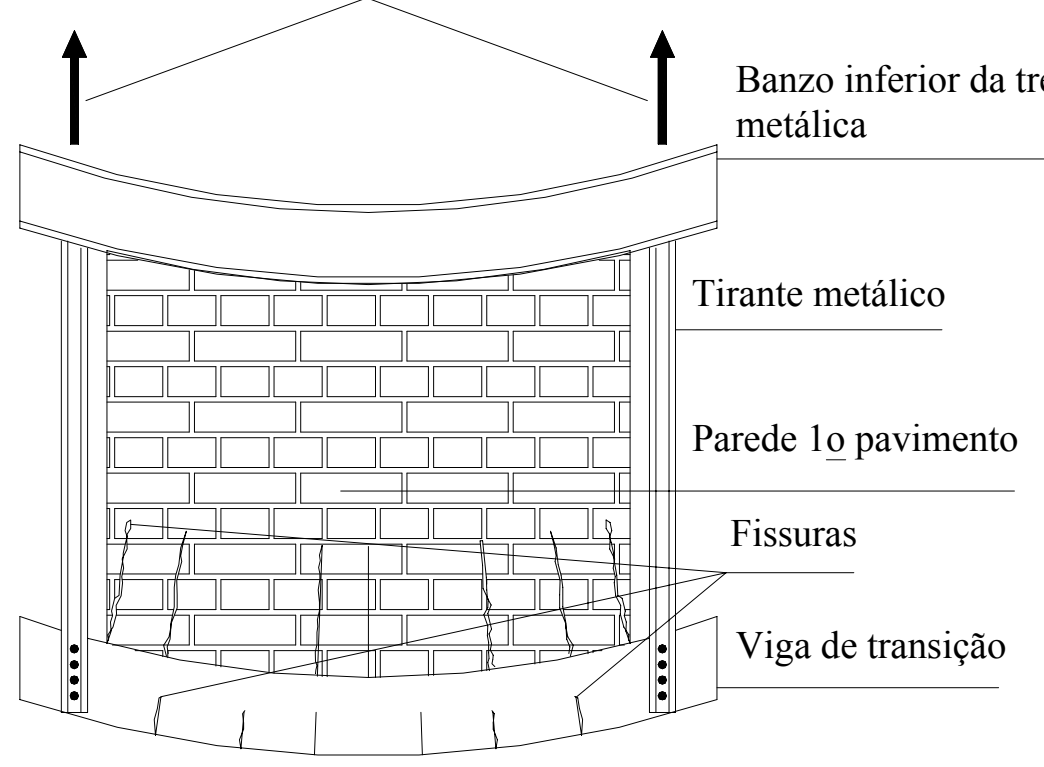

Figura 4.20 - Surgimento de fissuras nas paredes do primeiro pavimento.

As fissuras que se formariam nas paredes poderiam diminuir sua rigidez, o que aumentaria significativamente as flechas nas vigas, durante a elevação. Por esse motivo, julgou-se importante enrijecer as paredes com protensão, como foi descrito.

Força aplicada pelos cabos de aço

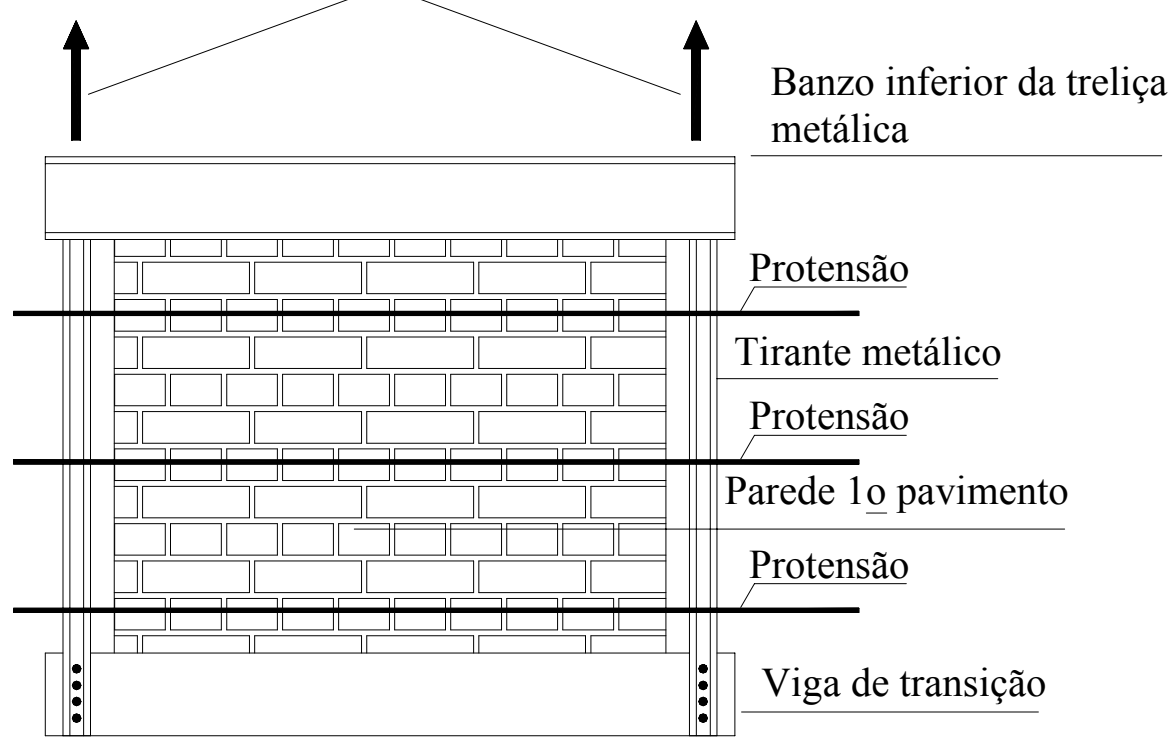

Figura 4.21 - Protensão nas paredes do primeiro pavimento. 
As ligações entre as paredes consideradas estruturais serão reforçadas com armadura e concreto nos espaços vazios, fazendo com que não haja perigo de desunião entre os elementos, quando forem solicitados no processo de recuperação.

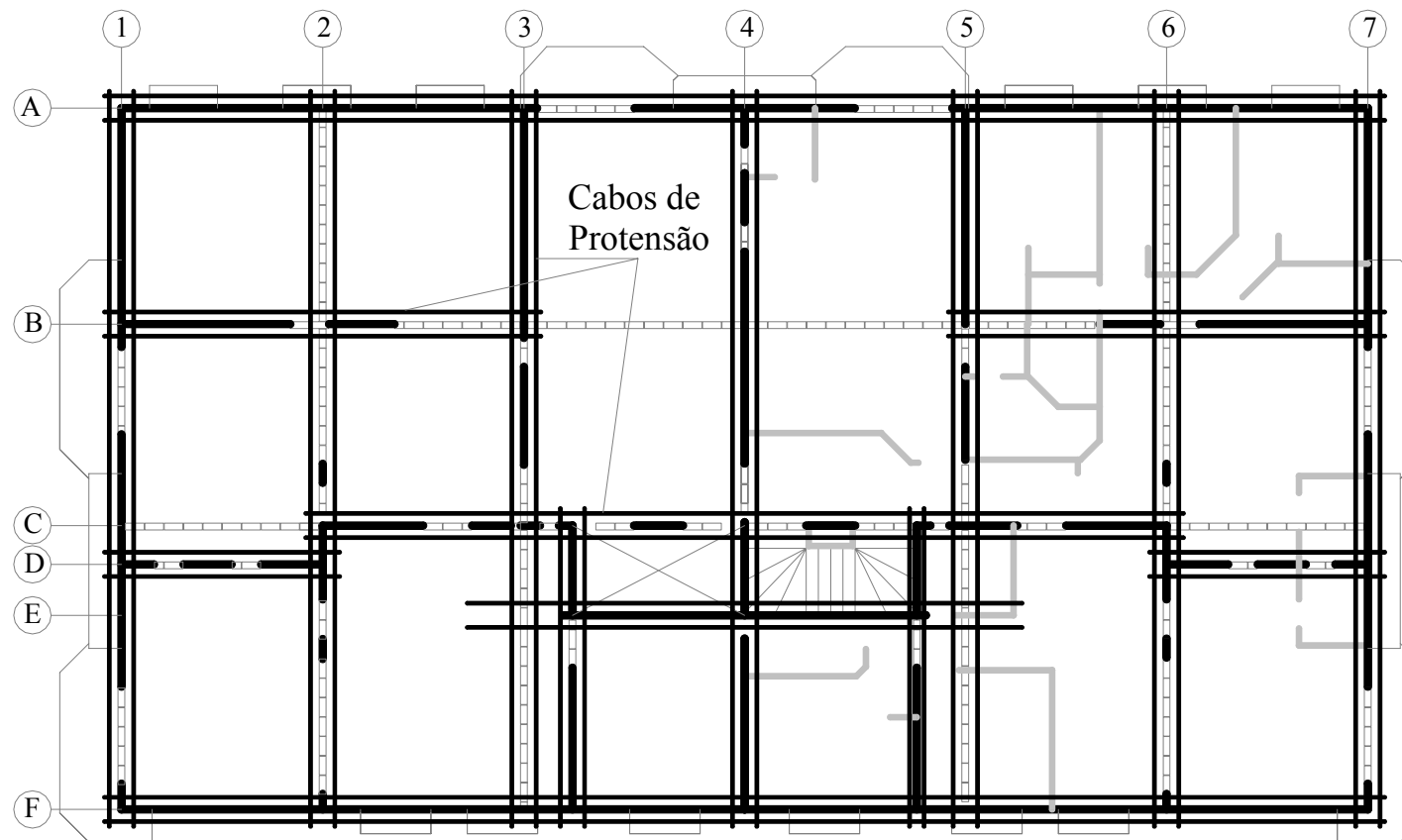

Figura 4.22 - Protensão para reforço nas paredes.

\subsubsection{ESTRUTURA METÁLICA}

Para erguer o edifício à sua cota original, o processo de reabilitação necessitará de uma estrutura metálica de caráter provisório. A estrutura será capaz de elevar o bloco desabado e sustentá-lo o tempo suficiente para que o pavimento térreo seja reconstruído. Após a recomposição de toda a sustentação definitiva de concreto armado no pavimento inferior, a estrutura auxiliar será desmontada e devolvida à “Companhia do Metropolitano de São Paulo" - responsável pelo empréstimo do material.

Inicialmente os engenheiros responsáveis pelo projeto estudaram várias alternativas capazes de realizar com sucesso a tarefa de elevação do edifício. Dentre elas, a que se configurou mais viável técnica e economicamente será posteriormente detalhada. 
Um dos sistemas propostos, não adotado, foi o de erguer o edifício através do uso de grandes vigas metálicas dispostas no primeiro pavimento (figura 4.23). Essas vigas suportariam todo o peso e elevariam a estrutura para a altura desejada.

Apesar de ser uma alternativa funcional e simples, ela traria alguns impecilhos que acabaram inviabilizando sua adoção: alto custo devido às grandes dimensões das peças, difícil manuseio no pavimento térreo, em função do peso excessivo, e custo adicional com guindaste para transporte.

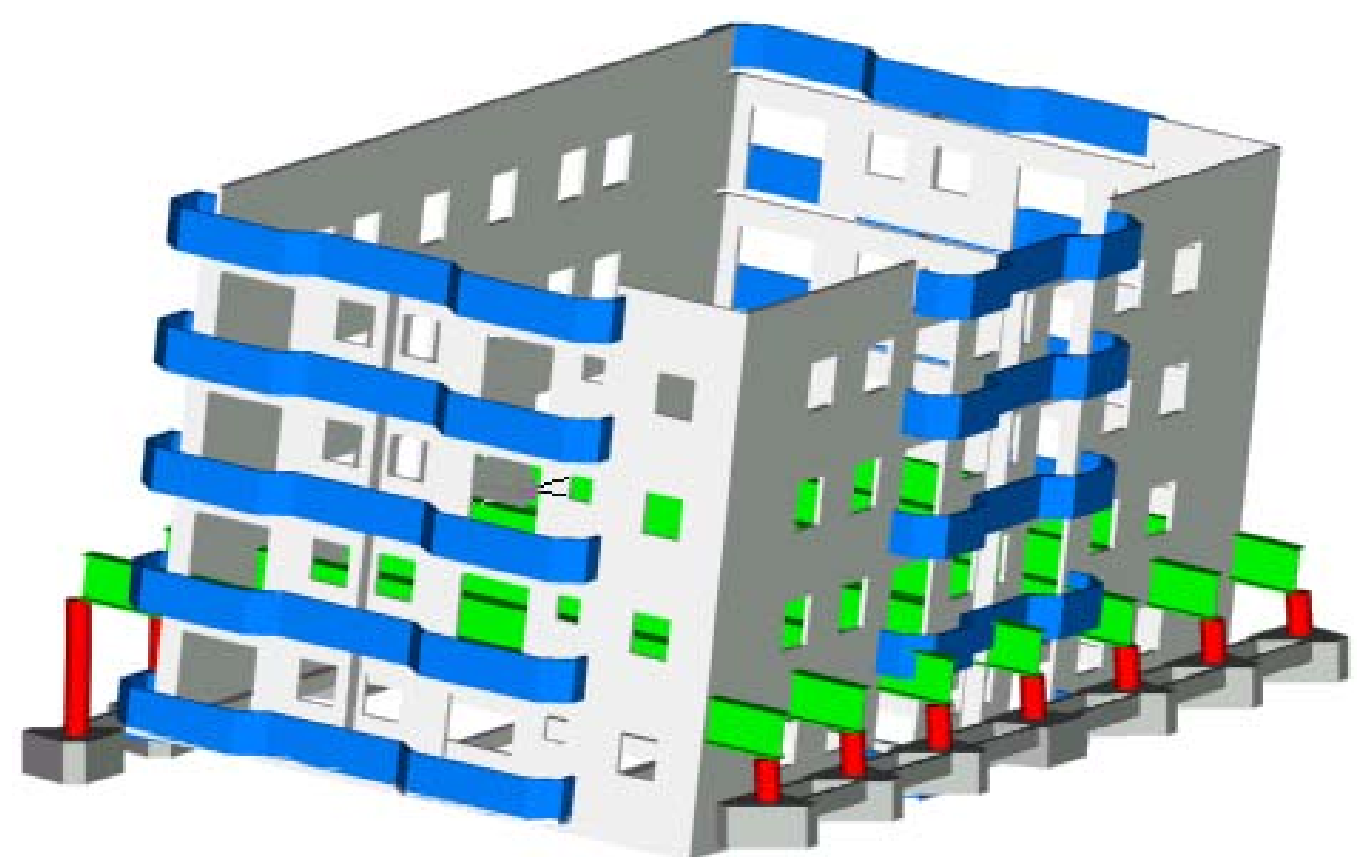

Figura 4.23 - Alternativa com vigas de grandes dimensões dispostas no primeiro pavimento.

Optou-se, portanto, pela adoção de um sistema estrutural mais otimizado, com peças leves e esbeltas, capaz de executar a tarefa e ao mesmo tempo de não exigir grandes despesas.

Sabendo que a treliça seria o modelo estrutural mais apropriado para alcançar o objetivo exposto, foi analisada a possibilidade da adoção de sete desses elementos, que seriam dispostos em cada eixo principal de recuperação.

Apesar da treliça idealizada ter altura suficiente para viabilizar o uso de montantes e de banzos com pequenas dimensões, ela acaba precisando de uma grande quantidade de elementos secundários, dispostos ao longo da altura da estrutura, para o encaminhamento dos esforços. Assim, se por um lado a estrutura 
proporcionaria baixo custo em seus principais elementos, como os montantes e os banzos, por outro lado ela exigiria um gasto maior na composição das peças consideradas secundárias (figura 4.24).

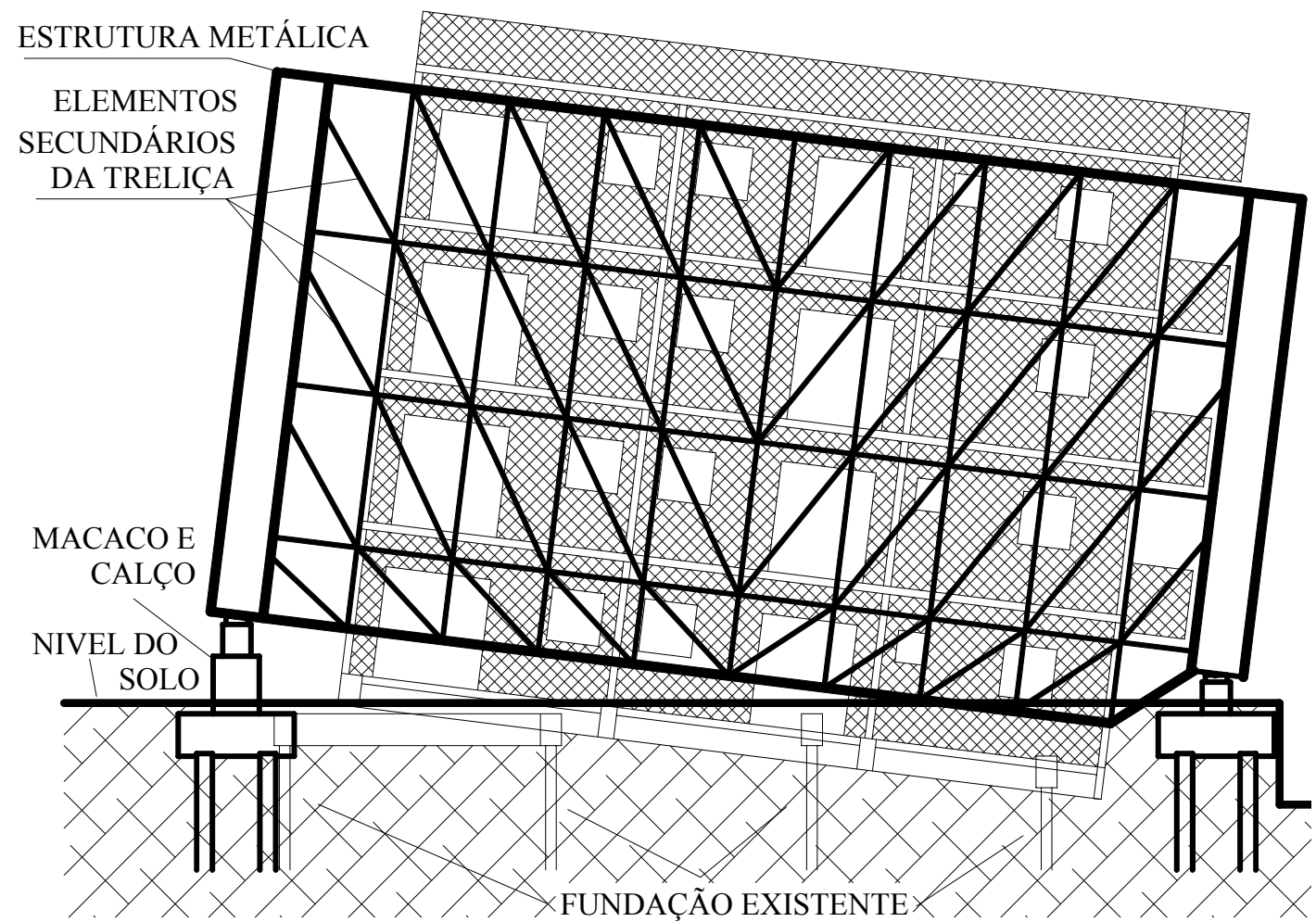

Figura 4.24 - Alternativa com estrutura treliçada disposta em toda a altura do prédio.

Para solucionar esse problema, decidiu-se adotar cabos de aço de alta resistência, que possuem baixo custo e desempenham a mesma função estrutural de tais elementos secundários, no sistema elaborado.

Cada uma das sete treliças de recuperação será composta por (figura 4.25):

- Dois montantes dispostos cada um de um lado do prédio, acompanhando a inclinação da estrutura;

- Banzo inferior posicionado no interior do primeiro pavimento e fixado rente às faces, debaixo das vigas sustentadoras do piso do segundo pavimento; 
- Banzo superior fixado no topo dos dois montantes, que será disposto sobre a laje da cobertura.

- Vários cabos inclinados de aço de alta resistência, usados para transportar o carregamento do banzo inferior aos montantes.

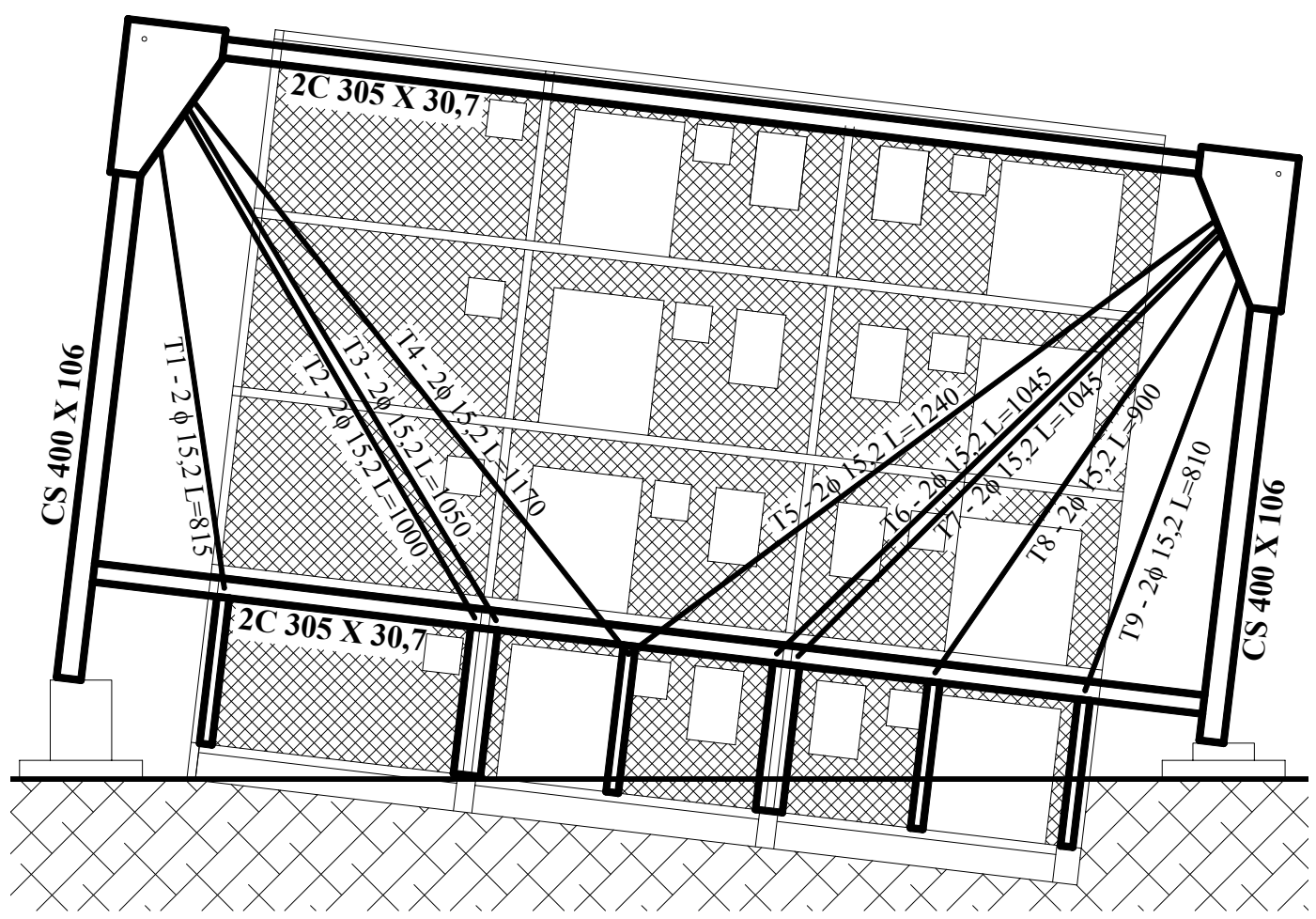

Figura 4.25 - Estrutura metálica usada para elevar a estrutura do edifício.

Ainda que a estrutura se aproxime bastante do comportamento de uma treliça clássica, na prática, inevitavelmente, alguns elementos irão sofrer flexão durante a movimentação do edifício desabado. Pelo fato da estrutura estar inicialmente inclinada e os montantes estarem engastados nos banzos, os carregamentos concentrados de reação nas fundações desenvolverão esforços de flexão em todos os elementos.

Como foi dito anteriormente, para evitar deslocamento excessivo da estrutura auxiliar, algumas paredes localizadas no primeiro pavimento serão incorporadas ao sistema de reabilitação. Elas serão protendidas com o propósito exclusivo de enrijecer a estrutura, dificultando a formação de fissuras no pavimento inferior. 
Várias cantoneiras metálicas farão a ligação entre essas paredes e a estrutura metálica. Os tirantes serão fixados nas vigas de transição, que se encontram embaixo das paredes, bem como no banzo inferior. Percebe-se que a estrutura montada no primeiro pavimento terá um comportamento semelhante ao de uma grande viga.

O próprio corpo do edifício desabado fará o travamento dos sete pórticos de elevação na direção perpendicular, evitando, dessa forma, um possível tombamento da estrutura auxiliar. A figura 4.26 mostra o posicionamento externo dos pórticos.

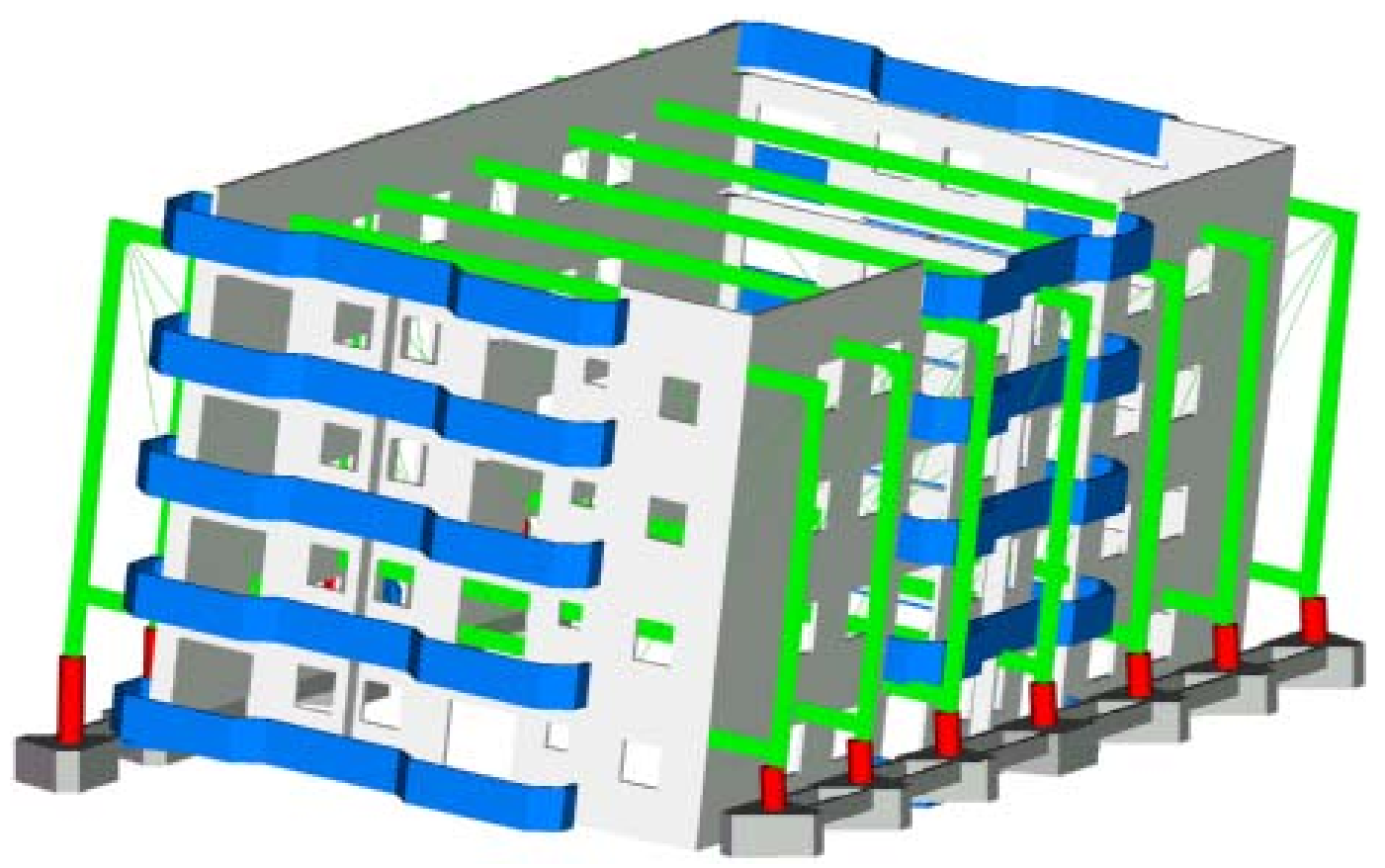

Figura 4.26 - Posicionamento da estrutura provisória no edificio.

Como os montantes serão deslocados para cima, no processo de reposicionamento do edifício, no início eles não serão fixados nos blocos de fundação, sendo apenas apoiados. Os cabos de aço, que conduzirão o peso de todo o edifício para o topo dos montantes, serão pré-tracionados no local em que serão dispostos e, se for necessário, serão novamente tencionados caso sofram afrouxamento durante a elevação do edifício. 
Os esforços na estrutura provisória, gerados pela sustentação do edifício, farão o seguinte percurso:

- Das vigas de transição, atualmente apoiadas no solo, aos banzos inferiores, posicionados no teto do primeiro pavimento; para tanto serão usadas as cantoneiras metálicas, conforme dito anteriormente;

- Dos banzos inferiores ao topo das montantes, através dos cabos inclinados;

- Do topo dos montantes às fundações provisórias.

\subsubsection{MACAQUEAMENTO E ESCORAMENTO}

Após toda a estrutura metálica provisória ter sido finalizada, iniciar-se-á a fase de içamento do bloco desabado. Os aparelhos especiais necessários para executar a tarefa serão fornecidos por uma empresa especializada no assunto.

Para erguer o edifício serão acoplados, embaixo dos montantes da estrutura, 14 macacos hidráulicos de capacidade para 200 tf. Todos eles poderão ser acionados individualmente. A força aplicada nos pistões será gerada por três bombas elétricas, que fornecerão ao sistema óleo sob alta pressão. Manômetros instalados, um para cada aparelho, permitirão saber, com precisão, o esforços aplicados nos 14 pontos da estrutura, que receberão as ações.

Não existe inicialmente uma ordem programada de acionamento dos macacos hidráulicos - eles serão solicitados de acordo com o comportamento da estrutura do edifício. Estima-se que dois meses será o período necessário para realizar a tarefa de içamento de toda a estrutura, até sua cota original.

O deslocamento ascendente será realizado a uma velocidade muito reduzida, com o propósito de evitar que ocorram grandes esforços e distorções: no plano da laje, no conjunto do edifício e na estrutura provisória.

Para garantir a segurança, à medida que o edifício for sendo macaqueado, pequenas chapas metálicas, com espessura da ordem de menos de um milímetro, serão introduzidas embaixo dos montantes, com o propósito de escorar a estrutura. Assim, se por algum motivo o sistema elevatório vier a falhar, a sustentação do 
edifício estará assegurada pelas chapas metálicas. Serão fixadas, também, chapas metálicas sobre os blocos de fundação, onde serão posicionados os macacos hidráulicos. Elas terão a finalidade de distribuir melhor os esforços na superfície de concreto.

Duas pilhas de escoramento serão posicionadas embaixo dos montantes, sendo uma de cada lado, para cada macaco hidráulico. Depois que o edifício ganhar uma certa altura, essas pilhas de chapas metálicas serão substituídas por elementos circulares de concreto mais espessos, da ordem de cinco centímetros cada um.

Como o edifício será levantado a uma altura superior ao tamanho do cursor do pistão, também será necessário, após uma determinada altura, calçar o macaco hidráulico.

Sabe-se que o edifício, além de abaixar quase $2,5 \mathrm{~m}$, sofreu outras duas movimentações: translação no sentido da Rua Tainha e rotação no sentido anti horário, tomando-se como referência quem observa da Av. Marginal para os fundos. Apesar da recuperação viabilizar o posicionamento da estrutura na cota original, não será possível recuperar a sua locação inicial em planta. Portanto, após ter sido levantada, a estrutura permanecerá em planta, na projeção horizontal da posição em que se encontra atualmente. A figura 4.27 mostra como ficará posicionado o edifício após sua suspensão.

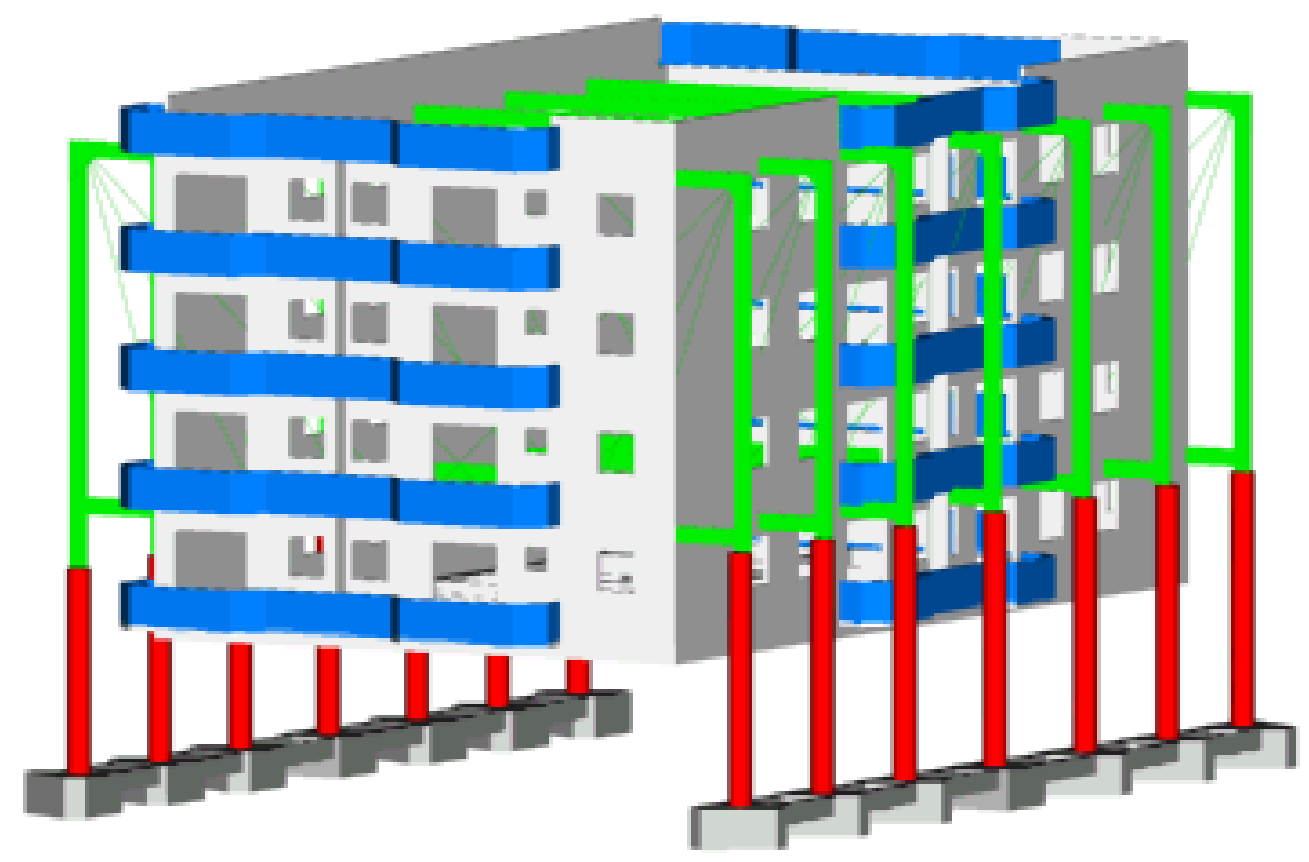

Figura 4.27 -Edificio posicionado em sua cota de origem. 


\subsubsection{RECONSTRUÇÃO DO PAVIMENTO TÉRREO}

A reconstrução do pavimento térreo será a última etapa a ser realizada, em todo processo de recuperação do bloco "B". Serão refeitos todos os elementos que foram danificados com o desabamento, como lajes, vigas, pilares e fundações. A reconstrução começará após o término do macaqueamento da estrutura.

Novas fundações farão a sustentação definitiva do edifício. Para isso novas estacas e vigas-baldrame serão executadas embaixo do edifício.

Serão reaproveitadas todas as vigas e as lajes do teto do pavimento térreo, que não sofreram avarias. As vigas de transição apoiar-se-ão sobre os novos pilares de concreto armado, os quais farão a sustentação definitiva do edifício. 


\subsection{PROBLEMAS VERIFICADOS DURANTE A OBRA}

Após o início das obras de recuperação, alguns problemas de natureza financeira inviabilizaram o projeto.

Apesar da estrutura metálica auxiliar, item de maior custo do projeto, ter sido elaborada para ser a mais econômica possível, o orçamento inicial ficou aquém do necessário. Talvez futuramente a compra do material poderia ter sido garantida com as contribuições mensais estipuladas aos condôminos. Porém a situação do edifício e o êxito de sua recuperação necessitavam de celeridade na solução.

Para tentar contornar tal problema, os responsáveis pela obra solicitaram, por intermédio da Prefeitura de Ubatuba, um empréstimo de todos os perfis metálicos necessários, junto à "Companhia do Metropolitano de São Paulo”. Tal material teria sido utilizado na construção do metrô de São Paulo e, após as obras, teria sido armazenado nas dependências da companhia.

Os responsáveis pela companhia, sensibilizados com o caso, concederam o pedido, mas houve uma grande demora na burocracia da aprovação do empréstimo. O tempo gasto nessa fase inviabilizou a continuidade do projeto e culminou com a necessidade de demolir o edifício, pois este já apresentava risco de desabamento total. 


\section{CAPÍtULO 5}

\section{CONCLUSÕES FINAIS}

Este trabalho descreveu o problema verificado no edifício. O objetivo foi abordar o assunto sob dois aspectos: estudo das causas do colapso e descrição das medidas que poderiam ter sido adotadas para solucionar o caso. Procurou-se, com isso, esclarecer importantes conceitos a serem assumidos em casos semelhantes. O texto narra os procedimentos emergenciais adotados para controlar o problema, as soluções assumidas e termina mencionando os resultados obtidos. As conclusões estão expostas nos itens 5.1 e 5.2 .

\subsection{MOTIVOS DO ACIDENTE}

Sabe-se que solo de natureza instável, componente predominante no subsolo do terreno estudado, está suscetível a extremo adensamento, caso atue nele um carregamento vertical. Logo, o aterro depositado sobre a base do pavimento térreo solicitou demasiadamente o material, visto que toda a superfície próxima à rua Tainha apresentou um notável recalque, poucos dias antes do colapso.

É importante dizer que, quando estacas de sustentação cruzam camadas de solo na situação aqui verificada, elas requerem atenção especial em seu dimensionamento, principalmente quando estão localizadas próximas a taludes, pois, devido ao efeito da sobrecarga vertical unilateral, estão sujeitas a expressivas pressões horizontais ao longo do fuste.

Portanto, é relevante dizer que o aterro teve papel fundamental na ruína do sistema.

\subsection{INVIABILIDADE DO PROJETO DE RECUPERAÇÃO}

No projeto de recuperação do edifício, a estrutura metálica provisória era o item de maior peso no orçamento. Sua execução deveria ter ocorrido logo no início das obras, pois através dela seria elevada toda estrutura do bloco desabado. Apesar 
do gasto estar previsto no projeto, os responsáveis pela recuperação do condomínio não dispunham da importância necessária para a aquisição do material. A administração do caixa da obra demandaria tempo para que esse montante fosse acumulado e, por conseguinte, seria inevitável a paralisação das atividades nesse período. No entanto, a estrutura do bloco "B" continuava a apresentar acréscimo de recalques e de inclinação.

Com base nisso, é oportuno destacar que o transtorno causado pelo acidente carecia de rápida solução, pois estava colocando em risco a vida dos moradores próximos, além de lesar os comerciantes da região.

Para contornar o problema, os administradores da obra solicitaram um empréstimo, sem sucesso, junto à Caixa Econômica Federal. Outra tentativa, também sem êxito, foi requerer um empréstimo, por intermédio da Prefeitura Municipal de Ubatuba, de perfis metálicos pertencentes à Companhia do Metropolitano de São Paulo. Tal material teria sido utilizado na construção do metrô de São Paulo e, após isso, armazenado nas dependências da Companhia.

Diante de todos esses impecilhos, o cronograma previsto para as obras não foi respeitado. O atraso chegou a ponto de, no dia $06 / 12$ / 02, o responsável técnico pelo projeto de recuperação, prudentemente, emitir um parecer constatando a inviabilidade da continuidade das obras e o iminente perigo de desabamento total da estrutura.

A grande falha no processo foi não ter solucionado o problema na sua origem, ou seja, não ter conseguido estabilizar o conjunto solo-estrutura ou, pelo menos, minimizar seus deslocamentos. Caso isso fosse feito, os interessados pela recuperação ganhariam tempo para somar mais divisas e arcar com as despesas exigidas.

Admitindo hipoteticamente que as obras de recuperação fossem concluídas até a fase de reconstrução do pavimento térreo, completamente destruído pelo desabamento, não é difícil imaginar que o custo envolvido nessa etapa também seria muito dispendioso, visto que seriam necessárias as recomposições de fundações, pilares, lajes e paredes. Além disso, ficaria comprometida a garantia do serviço, caso não fosse feito um reforço minucioso no subsolo, podendo apresentar, inclusive, problema semelhante no futuro. 
Comumente são notificados problemas decorrentes de recalques apresentados nas edificações. A interação solo-estrutura constitui um tema de difícil interpretação física, porém, os dois componentes estão intimamente relacionados. Sendo assim, não podem mais ser considerados isoladamente, como de costume.

Estudo de casos, como o realizado neste tratado, constituem um importante subsídio para o assunto, pois é através de experiências como essas que o meio técnico aprimora mais seus conhecimentos e torna-se cada vez mais apto para confrontar novos desafios. 


\section{REFERÊNCIAS BIBLIOGRÁFICAS}

ABRAMENTO, M ; KOSHIMA, A ; ZIRLIS, A.C. (1998). Reforço do terreno. In: HACHICH, W. et al., eds. Fundação: teoria e prática. 2.ed. São Paulo, Pini. cap. 18, p.641-649.

ACCETTI, K.M. (1998). Contribuição ao projeto de estruturas de edifícios em alvenaria. São Carlos. 247p. Dissertação (Mestrado) - Escola de Engenharia de São Carlos, Universidade de São Paulo.

ASSOCIAÇÃO BRASILEIRA DE NORMAS TÉCNICAS (2001), Revisão da NBR 6118 - Projeto de estruturas de concreto,

ASSOCIAÇÃO BRASILEIRA DE NORMAS TÉCNICAS (1996), NBR 6122 Projeto e execução de fundações, Rio de Janeiro, 33p,

ALONSO, U.R. (1998). Execução de fundações profundas: estacas injetadas. In: HACHICH, W. et al., eds. Fundação: teoria e prática. 2.ed. São Paulo, Pini. cap 9, p.361-399.

AMERICAN CONCRETE INSTITUTE (1981), ACI 343R-81 - Analysis and design of reinforced concrete bridge structures, ACI, Detroit,

AOKI, N. (1970). Esforços horizontais em estacas de pontes provenientes da ação de aterros de acesso. In: Anais do IV Congresso Brasileiro de Mecânica dos Solos e Engenharia de Fundações, Guanabara, 1970.

BEER. E. (1970). Piles subject to static lateral lads. IX International Conference on Soil Mechanics and Foundation Engineering, Tokyo, 1977. v.1, p.101-107. 
BEER. E., WALLAYS. M. (1972). Forces induced in piles by unsymmetrical surcharges on the soil around the piles. Fifth European Conference on Soil Mechanics and Foundation Engineering, Madrid, 1972. v.1, p.325-332.

CAPUZO NETO, V. (2000). Estudo teórico e experimental da interação de paredes de alvenaria estrutural submetidas a ações verticais. São Carlos. 111p. Dissertação (Mestrado) - Escola de Engenharia de São Carlos, Universidade de São Paulo.

CINTRA, J. C. A, (1998), Carregamento lateral em estacas, EESC-USP, São Carlos, 85p. (Reimpressão)

CUNHA, J. C. (1998). Palace II: A implosão velada da engenharia. Belo Horizonte, Autêntica.

GOTLIEB, M.; GUSMÃO, J. A. (1998). Reforço de fundações. In: HACHICH, W. et al., eds. Fundação: teoria e prática. 2.ed. São Paulo, Pini, cap.12, p.471-496.

HACHICH, W. et al. (1998). eds. Fundação: Teoria e prática. 2.ed. São Paulo, Pini.

MAFFEI, C. E. M. (2001). Relatório de visita do edifício Anêmona. Ubatuba / Relatório de visita.

MAFFEI, C. E. M. (2001). Memorial descritivo do método construtivo da recuperação do edifício Anêmona. Ubatuba / Relatório técnico.

MONTOYA, P. J.; MESEGUER, A. G.; CABRÉ, F. M. Hormigón armado - Abacos para el calculo de secciones en el estado ultimo de agotamiento, ed, 7, Gustavo Gili S,A, Barcelona, 
OTEO, C. S. (1977). Horizontally loaded piles: deformation influence. IX International Conference on Soil Mechanics and Foundation Engineering, Tokyo, 1977. V.1., p.1-15.

PFEIL, W. (1979), Pontes em concreto armado, Livros Técnicos e Científicos, São Paulo,

PINTO, C. S. (1998). Propriedades dos solos. In: HACHICH, W. et al., eds. Fundação: teoria e prática. 2.ed. São Paulo, Pini. cap. 2, p.51-118.

PUGLIESE, P. B. (1993). Estudo de estabilidade de aterros sobre solos moles. São Carlos. 156p. Dissertação (Mestrado) - Escola de Engenharia de São Carlos, Universidade de São Paulo.

QUARESMA, A. R. et al. (1998). Investigaç̃̃es geotécnicas. In: HACHICH, W. et al., eds. Fundação: teoria e prática. 2.ed. São Paulo, Pini, cap. 3, p.119-162.

RATTON, E. (1983). Etude par elements finis dês pieux charges lateralement en profondeur. Bruxelas. 313p. Tese (Doutorado) - Faculté des Sciences Appliquées, Universite de Bruxelles.

RIESE, L. E.; MATLOCK, H. (1956), Non-dimensional solutions for laterally loaded piles with soil modulus assumed proportional to depth, In: TEXAS CONFERENCE ON SOIL.

REIS, J. H. C. (2000). Interação solo-estrutura de grupo de edifícios com fundações superficiais em argila mole. São Carlos. 148p. Dissertação (Mestrado) - Escola de Engenharia de São Carlos, Universidade de São Paulo. 
ANEXO

DETALHES DO PROJETO ESTRUTURAL DO BLOCO "B" DO CONDOMÍNIO "ANÊEMNA" 